US Army Corps

of Engineers ${ }_{\circledast}$

Engineer Research and

Development Center

Dredging Operations and Environmental Research Program

\title{
Evaluation of Biodiesel Fuels to Reduce Fossil Fuel Use in Corps of Engineers Floating Plant Operations
}

Michael Tubman, Timothy Welp, Ryan Immel,

July 2016

and Robert Leitch 
The U.S. Army Engineer Research and Development Center (ERDC) solves the nation's toughest engineering and environmental challenges. ERDC develops innovative solutions in civil and military engineering, geospatial sciences, water resources, and environmental sciences for the Army, the Department of Defense, civilian agencies, and our nation's public good. Find out more at www.erdc.usace.army.mil.

To search for other technical reports published by ERDC, visit the ERDC online library at http://acwc.sdp.sirsi.net/client/default. 


\section{Evaluation of Biodiesel Fuels to Reduce Fossil Fuel Use in Corps of Engineers Floating Plant Operations}

Michael Tubman and Timothy Welp

Coastal and Hydraulics Laboratory

U.S. Army Engineer Research and Development Center

3909 Halls Ferry Road

Vicksburg, MS 39180-6199

Ryan Immel

U.S. Army Corps of Engineers Marine Design Center

U.S. Army Engineer District, Philadelphia

100 Penn Square East

Philadelphia, PA 19107-3390

Robert Leitch

Headquarters

U.S. Army Corps of Engineers

441 G Street NW

Washington, DC 20314-1000

Final report

Approved for public release; distribution is unlimited.

Prepared for U.S. Army Corps of Engineers

Washington, DC 20314-1000

Under Work Unit 456009, "Feasibility of Using Biodiesel" 


\section{Abstract}

A study to evaluate the feasibility of using biodiesel fuel in U.S. Army Corps of Engineers (USACE) floating plant operations to reduce environmentally sensitive emissions, increase use of renewable energy, and reduce the use of fossil fuels was conducted with funding from the U.S. Army Corps of Engineers (USACE) Dredging Operations and Environmental Research (DOER) program and the USACE Sustainability and Energy Efficiency Program. This study was conducted by the USACE Engineer Research and Development Center (ERDC) and the USACE Marine Design Center (MDC), in conjunction with support of USACE Headquarters (HQUSACE) and participating USACE Districts. The study began in 2010 with a focus on the methodology to convert four working USACE vessels to biodiesel. Favorable results in regards to mechanical and operational issues cleared the way for evaluating biodiesel on additional vessels. Fourteen vessels were converted to biodiesel use in the expanded study, and additional tests of emissions and fuel usage were conducted on two vessels. This report describes the study that successfully demonstrated that use of certified biodiesel fuel (including biodiesel manufactured from soybeans and from algal oils) by suitable USACE floating plants is feasible to reduce select environmentally sensitive emissions, increase USACE use of renewable energy, and reduce the use of fossil fuels.

DISCLAIMER: The contents of this report are not to be used for advertising, publication, or promotional purposes. Citation of trade names does not constitute an official endorsement or approval of the use of such commercial products. All product names and trademarks cited are the property of their respective owners. The findings of this report are not to be construed as an official Department of the Army position unless so designated by other authorized documents. 


\section{Contents}

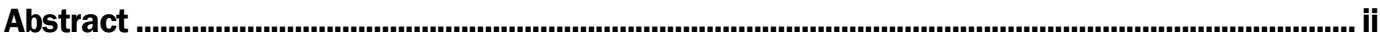

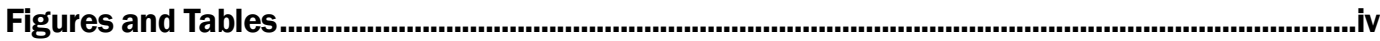

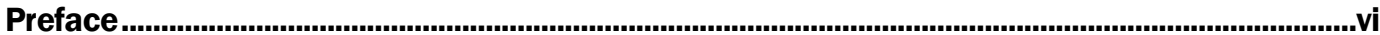

Unit Conversion Factors …........................................................................................................ viii

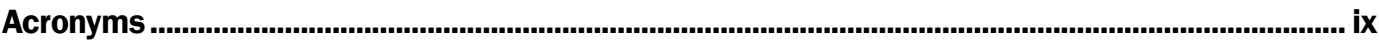

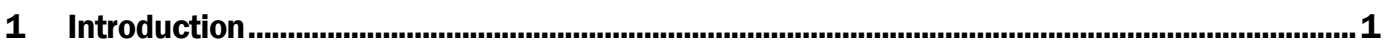

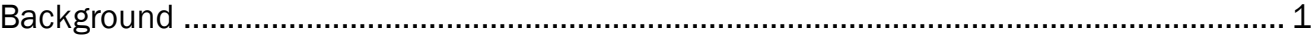

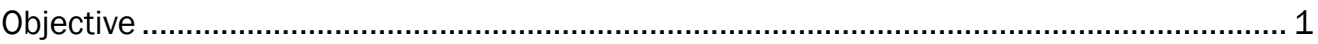

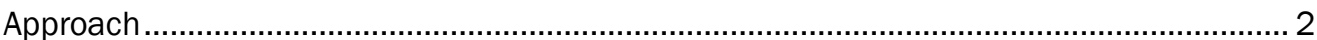

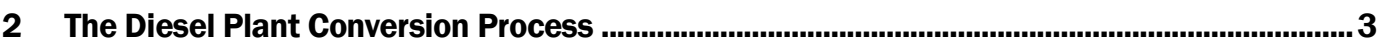

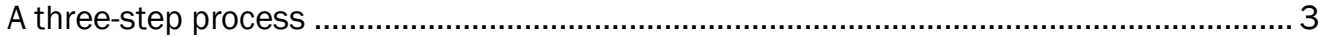

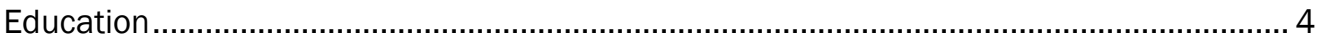

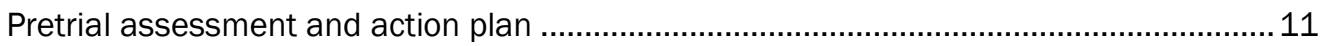

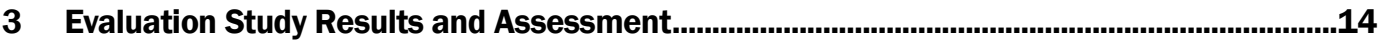

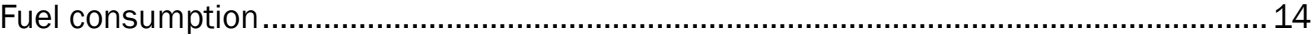

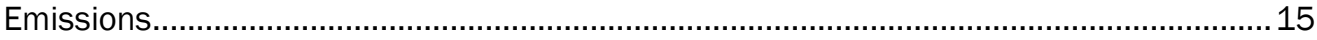

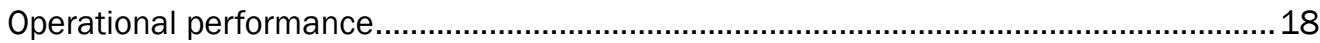

4 Expanded Operational Experience and Improved Testing of Emissions and Fuel

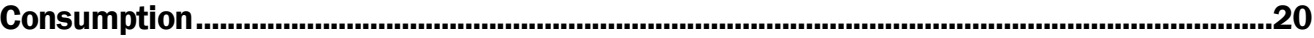

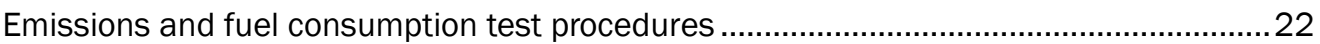

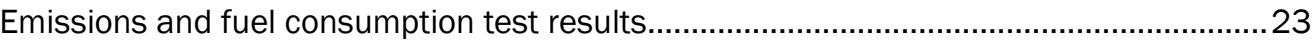

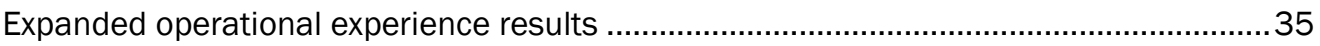

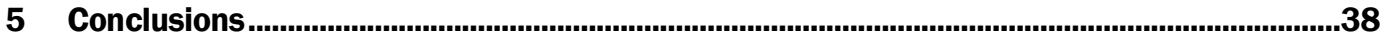

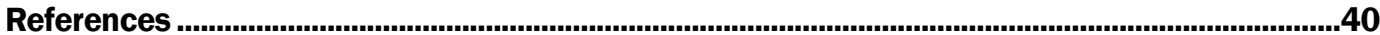

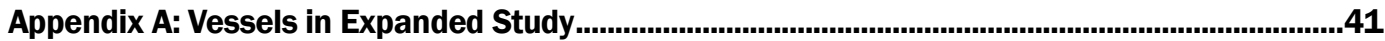

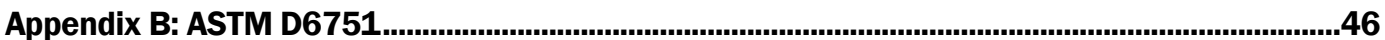

Appendix C: B100 Test Results..............................................................................................47

Report Documentation Page 


\section{Figures and Tables}

\section{Figures}

Figure 1. U.S. Army Engineer District Baltimore (NAB) drift collection vessel $B D-5 \ldots \ldots \ldots \ldots \ldots \ldots \ldots \ldots \ldots \ldots . . .7$

Figure 2. U.S. Army Engineer District St. Louis (MVS) towboat Pathfinder............................................

Figure 3. U.S. Army Engineer District San Francisco (SPN) debris boat Raccoon................................. 8

Figure 4. U.S. Army Engineer District Buffalo (LRB) tug Mike Donlon.................................................... 8

Figure 5. Raccoon starboard propulsion engine (A) with FlowScan fuel-flow interface meter components, (B) fuel consumption LCD readout, and (C) fuel-line flow meter (one installed on the fuel supply line and one installed on the fuel return line).......................................10

Figure 6. The Mike Donlon conducting a push test...........................................................................11

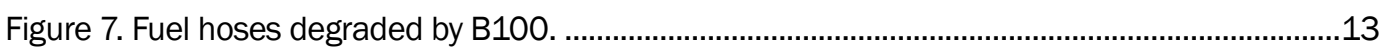

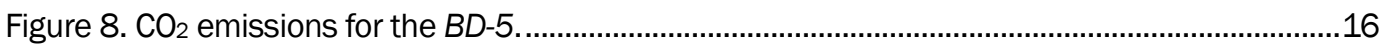

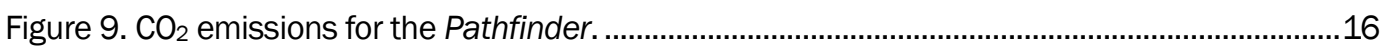

Figure 10. $\mathrm{CO}_{2}$ emissions for the Mike Donlon.............................................................................

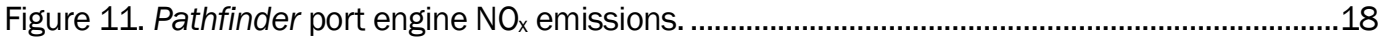

Figure 12. Output of NMEA2000 Interface to FlowScan fuel-flow monitoring system......................21

Figure 13. Emissions testing instrumentation connected directly into the exhaust stack on

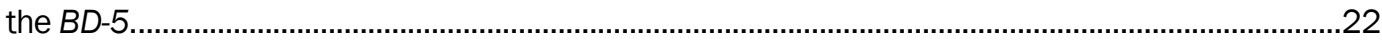

Figure 14. Fuel consumption versus engine power for the Raccoon................................................24

Figure 15. Brake-specific fuel consumption of B100 (blue), ULSD (green), and Solazyme (red) fuels for the Raccoon. ................................................................................................................24

Figure 16. Emissions of $\mathrm{CO}_{2}$ versus engine power for the Raccoon................................................25

Figure 17. Emissions of $\mathrm{CO}_{2}$ for $\mathrm{B} 100$ (blue), ULSD (green), and Solazyme (red) fuels for

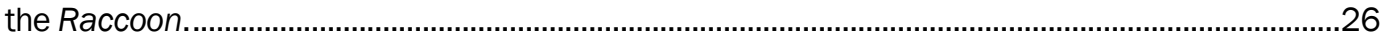

Figure 18. Emissions of $\mathrm{CO}$ versus engine power for the Raccoon. ..................................................26

Figure 19. Emissions of CO for B100 (blue), ULSD (green), and Solazyme (red) fuels for

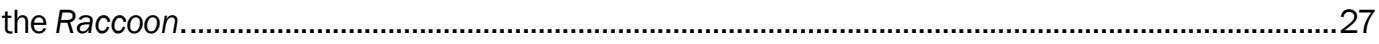

Figure 20. Emissions of $\mathrm{NO}_{x}$ versus engine power for the Raccoon.................................................2

Figure 21. Emissions of $\mathrm{NO}_{x}$ for B100 (blue), ULSD (green), and Solazyme (red) fuels for

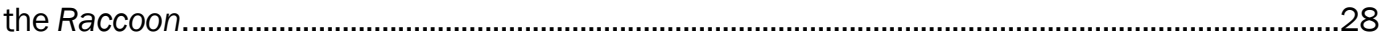

Figure 22. Emissions of $\mathrm{PM}_{2.5}$ versus engine power for the Raccoon............................................28

Figure 23. Emissions of PM2.5 for B100 (blue), ULSD (green), and Solazyme (red) fuels for the Raccoon.

Figure 24. Fuel consumption versus engine power for the port engine (right) and the starboard engine (left) for the BD-5 .......................................................................................

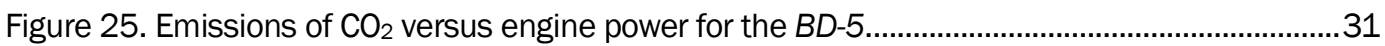

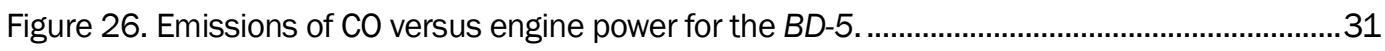

Figure 27. Emissions of $\mathrm{NO}_{x}$ versus engine power for the $\mathrm{BD}-5$...................................................32

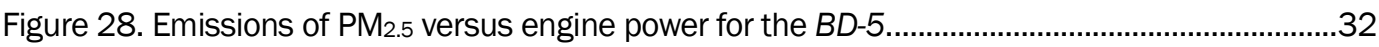


Figure A1. U.S. Army Engineer District Baltimore (NAB) drift collection vessel BD-6........................42

Figure A2. U.S. Army Engineer District St. Louis (MVS) dustpan dredge Potter..................................42

Figure A3. U.S. Army Engineer District Portland (NWP) hopper dredge Yaquina. ..............................43

Figure A4. U.S. Army Engineer District St Louis (MVS) towboat GrandTower.....................................43

Figure A5. U.S. Army Engineer District St Louis (MVS) towboat Prairie du Rocher ............................43

Figure A6. U.S. Army Engineer District St Louis (MVS) towboat Kimmswick......................................44

Figure A7. U.S. Army Engineer District St Louis (MVS) crane barge Fisher...........................................44

Figure A8. U.S. Army Engineer District St Louis (MVS) crane barge Sewell. .......................................44

Figure A9. U.S. Army Engineer District St Louis (MVS) crewboat Barron...........................................45

Figure A10. U.S. Army Engineer District St Louis (MVS) crane barge Derrick Number 6...................45

\section{Tables}

Table 1. Biodiesel evaluation study floating plant equipment descriptions. 6

Table 2. Average B100 fuel consumption compared to No.2 diesel fuel consumption for the run tests (positive numbers indicate increased B100 consumption and negative numbers indicated lower B100 consumption).

Table 3. Average B100 fuel consumption compared to No.2 diesel fuel consumption for the push tests (positive numbers indicate increased B100 consumption and negative numbers indicated lower B100 consumption)

Table 4. Average emissions values (D - No. 2 diesel and B - B100) of the port and

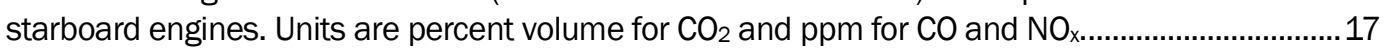

Table 5. Raccoon diesel costs. ...................................................................................................19

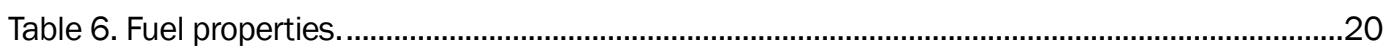

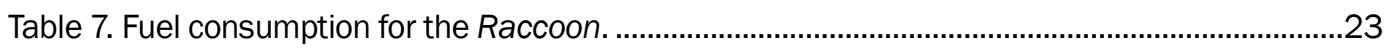

Table 8. Emissions of $\mathrm{CO}_{2}$, $\mathrm{CO}$, and $\mathrm{NO}_{x}$ for the Raccoon............................................................25

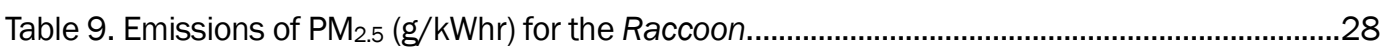

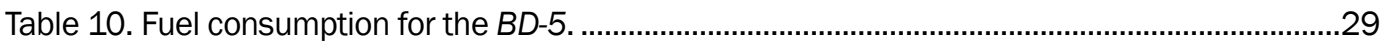

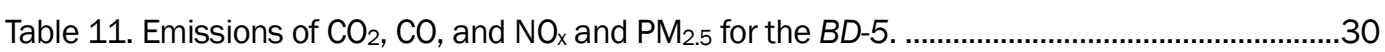

Table 12. Weighted emissions factors for the Raccoon (g/kWhr)...................................................35

Table A1. Expanded operational testing and biodiesel evaluation study of floating plant equipment descriptions................................................................................................................. 41 


\section{Preface}

This study was conducted for the Headquarters, U.S. Army Corps of Engineers, (HQUSACE) under the Dredging Operations and Environmental Research (DOER) Program, Work Unit 456009, "Feasibility of Using Biodiesel." The technical monitor was Dr. Todd Bridges (CEERD-EM-D).

The work was performed by the Coastal Engineering Branch of the Navigation Division (CEERD-N), U.S. Army Engineer Research and Development Center, Coastal and Hydraulics Laboratory (ERDC-CHL). At the time of publication, Tanya Beck was Chief, CEERD-HN-C; Dr. Jackie Pettway was Chief, CEERD-HN; and Jeffery Lillycrop, CEERD-HT was the Technical Director for Navigation. The Director of CHL was José E. Sánchez.

This effort was supported by the USACE Dredging Operations and Environmental Research (DOER) Program (http://el.erdc.usace.army.mil/dots/ doer/doer.html) and the USACE Sustainability and Energy Efficiency Program. The DOER Program is managed at the U.S. Army Engineer Research and Development Center (ERDC) by Dr. Todd Bridges, Environmental Laboratory (EL), and Charles E. Wiggins, Coastal and Hydraulics Laboratory (CHL). The USACE Sustainability and Energy Efficiency Program is managed by John Coho, HQUSACE.

DOER is administered at CHL under the USACE Navigation Research, Development, and Technology Transfer (RD\&T) Program. At the time this effort was conducted, James Walker was the HQUSACE Navigation Business Line Manager overseeing the DOER Program. Jeffery Lillycrop, CHL, was the ERDC Technical Director for Civil Works and Navigation RD\&T. Charles E. Wiggins, CHL, was the ERDC Associate Technical Director for Navigation.

This study would not have been possible without the managers and crews in the U.S. Army Engineer Districts Baltimore, Buffalo, San Francisco, Portland, New York, and St. Louis who volunteered the use of their vessels. The authors wish to express thanks to the management and crews of the USACE vessels $B D-5$ and $B D-6$ (Captain Jeff Peacock, Corey Griffing, 
Steve Golder, Benjamin Birney, Andy Boyle, Langston Spencer, and Joe Huber), Donlon (Paul Bijhouwer, Timothy Colburn, Dennis Claycomb, and Timothy Zbin), Raccoon (Kent Danielson, Captain Joe McCormick, Erick Romani, Dave Whelsdon, Paul Tietjen, Rick Curry, Dan Denofrio, and Marty Plisch), Pathfinder (Jared Schmidt, Gary Lowe, Lance Engle, Captain Terry Bequette, Mike Morgan, Tom Brace, Larry Baltzell and Bret Leavitt), Potter (Chris Stokes and members of Potter crew), Grandtower (Scott Lussier), Yaquina (Jerry Gompers, Captain Mark Keen, Captain Jonathan Blake, Erik Risheim, Steve Burock, and other members of Yaquina crew ), and Gelberman (Liz Finn and Bill Lyness). The authors thank Captain David Beal (MVS) for his support of the project.

Vessel power and emissions testing was conducted by the Bristol Harbor Group (Russel Bostock) and the Center for Environmental Research and Technology, University of California, Riverside (Nicholos Gysel, William Welch, and Wayne Miller). USACE is part of a Federal Green Fleet working Group that includes members from the National Oceanographic and Atmospheric Administration (NOAA), Army Petroleum Center (APC), United States Army Tank Automotive Research, Development and Engineering Center (TARDEC), Defense Logistics Agency (DLA ENTERGY), Maritime Administration (MARAD), U.S. Navy (USN), and the U.S. Coast Guard (USCG).

At the time of publication of this report, the Commander of ERDC was COL Bryan S. Green, and the Director was Dr. Jeffery P. Holland. 


\section{Unit Conversion Factors}

The conversions between non-SI units of measurement and SI (metric) units in this report are as follows:

\begin{tabular}{|l|c|l|}
\hline Multiply & By & To Obtain \\
\hline feet & 0.3048 & Meters \\
\hline pound-mass per cubic foot & 16.0185 & grams per cubic centimeter \\
\hline pound-mass & 0.4536 & Kilograms \\
\hline gallon & 3.7854 & Liters \\
\hline horsepower & 745.7000 & Watts \\
\hline pound-mass & 453.5929 & Grams \\
\hline $\begin{array}{l}\text { Grams per cubic centimeter }\left(\mathrm{g} / \mathrm{cm}^{3}\right) \text { can be converted to grams per liter }\left(\mathrm{g} / \mathrm{L}, \text { equivalent to } \mathrm{kg} / \mathrm{m}^{3}\right) \mathrm{by} \\
\text { multiplying by } 1000 .\end{array}$
\end{tabular}




\section{Acronyms}

The test standard acronyms in this report are

- ASTM - American Standard Testing Methods

- ISO - International Standards Organization. 


\section{Introduction}

\section{Background}

The U.S. Army Corps of Engineers (USACE) has approximately 2,300 floating plant assets that consist of (in an approximate order of magnitude) barges, tow boats, floating cranes, survey boats, patrol boats, and the minimum fleet dredges. The fiscal year (FY) 2010 fuel consumption was approximately 31.378 million liters (8.290 million gallons) of diesel. On 5 October 2009, Executive Order 13514 was issued by President Obama (Council on Environmental Quality 2009) that requires Federal agencies to develop a strategic sustainability performance plan (SSPP) to reduce energy consumption and greenhouse gas emissions, increase agency use of renewable energy, and reduce the use of fossil fuels. For USACE floating plant, one of the main strategies of the USACE SSPP is reducing diesel fuel consumption, and a potential way to accomplish that is to substitute biodiesel for regular petroleum-derived diesel.

Biodiesel is a domestic, renewable fuel originating from plant or animal feed stocks. Biodiesel manufactured from soybeans was selected for the initial evaluation phase because of the high success experienced by the National Oceanographic and Atmospheric Administration's (NOAA) Lake Michigan Field Station (LMFS). The LMFS has successfully used biodiesel manufactured from soybeans in a variety of vessels for over 10 years in Muskegon, MI. During that time they experimented with different blends of biodiesel such as B2O (20\% biodiesel, $80 \%$ diesel) and have found that B99.9 (99.9\% biodiesel, 0.1\% diesel) is the most reliable and problem-free type of biodiesel. Biodiesel B99.9, being a blend of biodiesel and regular diesel, exists due to tax incentives enacted for certain types of blended fuels. Technically, B100, unblended biodiesel, is different; however, practically, its properties are nearly indistinguishable from B99.9. In this report, pure biodiesel will be referred to as B100, regardless of whether it is B99.9 or B100.

\section{Objective}

The objective of this study was to evaluate the use of biodiesel fuel in U.S. Army Corps of Engineers (USACE) floating plant operations to reduce 
environmentally sensitive emissions, increase use of renewable energy, and reduce the use of fossil fuels.

\section{Approach}

The evaluation study began in 2010 with a focus on the methodology to convert four working USACE vessels to biodiesel. The vessels were made available by USACE Districts Baltimore (NAB), St. Louis (MVS), San Francisco (SPN), and Buffalo (LRB). A large part of LMFS success is due to the careful methodology that was applied. Information, education, and participation were key elements in bringing people on board, explaining both the purpose and the process in detail, and cultivating beneficial relationships with vessel operators, crews, suppliers, and regulatory agencies. In LMFS experience, once the initial change occurred, the crew assessments were that the use of biodiesel was a "non-issue" and that the "benefits outweighed the hassles." Another critical relationship was with the original engine manufacturers (OEM), where the major diesel engine manufacturer's representatives were involved from the beginning for their validation and participation. USACE decided to emulate the LMFS approach for the USACE evaluation study.

After successfully converting the four USACE vessels to biodiesel, preliminary results indicated that engine performance, maintenance, and operational efficiency, were not adversely impacted by using biodiesel fuel. Results from tests on fuel consumption and emissions were found to be limited by the technical level of the evaluation methodology. This led to evaluating biodiesel usage in an increased number and more diverse types, of vessels and additional testing of first- and second-generation biodiesel fuels with improved monitoring of fuel consumption and emissions. 


\section{The Diesel Plant Conversion Process}

\section{A three-step process}

The conversion process consists of three distinct steps which lead to the actual mechanical conversion to the vessels. The emphasis is on improving education and understanding of the entire fuel process as a required qualification before moving on to any physical conversions. The steps are as follows:

1. Education
a. Benefits of biodiesel
b. Myths, misinformation, and past experiences
c. Similarities and differences
d. Areas of concern
e. Implementation plan
f. Monitoring plan
g. Response plan
h. Measures and conclusions

2. Pretrial Assessment
a. Resources and personnel
b. Fuel tank(s)
c. Residual fuel condition
d. Distribution
e. Filtration
f. Injection pumps
g. Engine - external condition
h. Engine - performance issues
i. Exhaust measures

3. Action Plan
a. Biodiesel supplier evaluation
b. Training and expectations
c. Measures and alternatives
d. Address mechanical issues/impacts
e. Consider process improvements/impacts 


\section{Education}

Benefits of using biodiesel include (DOE 2003) include the following:

- lower emissions than petroleum-based fuels

- lower environmental impact - as biodegradable as sugar and ten times less toxic than table salt

- renewable energy source

- improved health and safety - less-offensive odor, higher flash point, can reduce carcinogenic properties (compared to diesel fuel) by $94 \%$

- improved engine performance - higher lubricity and solvent levels.

Much of the educational process was addressed by the formation of the Federal Non-Tactical Vessel (FNTV) Biodiesel Initiative, which was created to explore the operational feasibility of expanding the use of B100 in nontactical Federal vessels operated primarily by NOAA, USACE, and MARAD. Other members of the FNTV include personnel from the APC, TARDEC, DLA ENTERGY, USN, and USCG. The FNTV Working Group convened in August 2010 to review the methodology proven through the demonstrated success of LMFS in using B100 in a variety of vessels over the preceding 10 years. LFMS data relating to the differences in fuel costs, reduced maintenance, health and safety issues, and reduced greenhouse gas emissions of B100 compared to diesel fuel were examined in detail by members of the working group. Also discussed were several other reports and sources of data from industry, the department of Energy's Office of Energy Efficiency and Renewable Energy (EERE), and the National Biodiesel Board. Based on this review and consensus by the FNTV, USACE spearheaded an expansion of the scope of NOAA testing to cover a variety of USACE vessels.

The FNTV Working Group's review of available information and past experiences led to its endorsement of LMFS experience that the use of biodiesel was not an issue with vessel operators and that the benefits outweighed any difficulties encountered in converting to biodiesel. However, they did identify the following areas of concern:

1. Cold-flow properties

Similar to regular diesel, but more pronounced for biodiesel, solid crystals can form in the fuel at relatively higher (than diesel) temperatures. These crystals can plug filters, and at lower 
temperatures, so many agglomerated crystals can form that the fuel will no longer flow.

2. Material compatibility

B100 may soften and degrade certain types of rubber compounds used for hoses and gaskets and may cause them to leak or degrade.

3. Microbial growth

Biodiesel will grow microbes, much as diesel will.

4. Combustion properties

The energy content of soybean based biodiesel is $7 \%$ to $10 \%$ less by volume than that of regular No. 2 diesel fuel (DOE 2003).

5. Filter plugging

As a result of B100 solvent properties, any accumulated deposits in an existing fuel tank and system will be dissolved and carried through the system where they can clog filters.

6. Water separation

B100 is capable of holding water in the amount of approximately $1 \%$ of its volume. The presence of water in fuel reduces combustion heat, increases corrosion and pitting, accelerates microbe growth, and provides nucleation sites for cold-flow gelling (DOE 2003).

7. Storage stability

The National Biodiesel Board (NBB) states that industry experts recommend that to maintain the quality of the fuel, biodiesel should be used within 6 months of purchase.

8. OEM warranties

Engine manufacturers generally state that several biodiesel fuel-related issues can have a detrimental effect on engine performance and condition. 
9. Cost

Biodiesel prices vary across the country and tend to be "slightly higher" than those for petroleum diesel (DOE 2014).

The implementation plan addressed the identified areas of concern.

The USACE implementation plan specified an evaluation study to be conducted on four USACE vessels:

- the $B D-5$, a drift collection vessel used by the Washington, DC, Debris Unit (NAB)

- the Pathfinder, a towboat at the St. Louis, MO, Base Yard (MVS)

- the Raccoon, a debris boat at the Sausalito, CA, Base Yard (SPN)

- the Mike Donlon, a tug used by the Buffalo, NY, District (LRB).

Descriptions of these floating plant and installed diesel equipment are presented in Table 1, and their respective photographs shown in Figures 1 through 4 .

Table 1. Biodiesel evaluation study floating plant equipment descriptions.

\begin{tabular}{|l|l|l|l|l|l|}
\hline Location & District & Vessel & $\begin{array}{l}\text { Fuel Usage } \\
\text { (L/hr) } \\
\text { (gal/hr) }\end{array}$ & Propulsion & Generator \\
\hline $\begin{array}{l}\text { Washington, DC } \\
\text { Debris Unit }\end{array}$ & NAB & $\begin{array}{l}\text { BD-5 (11 m) drift } \\
\text { collection vessel, } \\
1991, \text { fuel cap, } \\
1,892 \mathrm{~L} \\
\text { (500 gal) }\end{array}$ & $\begin{array}{l}7.6 \\
(2)\end{array}$ & $\begin{array}{l}\text { 2 Cummins } \\
\text { 6BTA5.9M3 }\end{array}$ & $\begin{array}{l}\text { 1 Yanmar, YDG } \\
\text { 3700EV, Engine } \\
\text { Model } \\
\text { L70V6HJ1COGAYG }\end{array}$ \\
\hline $\begin{array}{l}\text { St. Louis, MO } \\
\text { Base Yard }\end{array}$ & MVS & $\begin{array}{l}\text { Pathfinder (23 m) } \\
\text { towboat, 1995, fuel } \\
\text { cap. 51,300 L } \\
(13,555 \text { gal) }\end{array}$ & $\begin{array}{l}378.5 \\
(100)\end{array}$ & 2 Caterpillar 3412 & 2 Caterpillar 3304 \\
\hline $\begin{array}{l}\text { Sausalito, CA } \\
\text { Base Yard }\end{array}$ & SPN & $\begin{array}{l}\text { Raccoon (30 } \mathrm{m}) \\
\text { debris boat, 1949, } \\
\text { fuel cap. 4,542 L } \\
(1,200 \text { gal) }\end{array}$ & $\begin{array}{l}56.8 \\
(15)\end{array}$ & $\begin{array}{l}\text { 2 Cummins } \\
\text { QSK19-M }\end{array}$ & 1 Onan \\
4045TFM75A
\end{tabular}


Figure 1. U.S. Army Engineer District Baltimore (NAB) drift collection vessel BD-5.

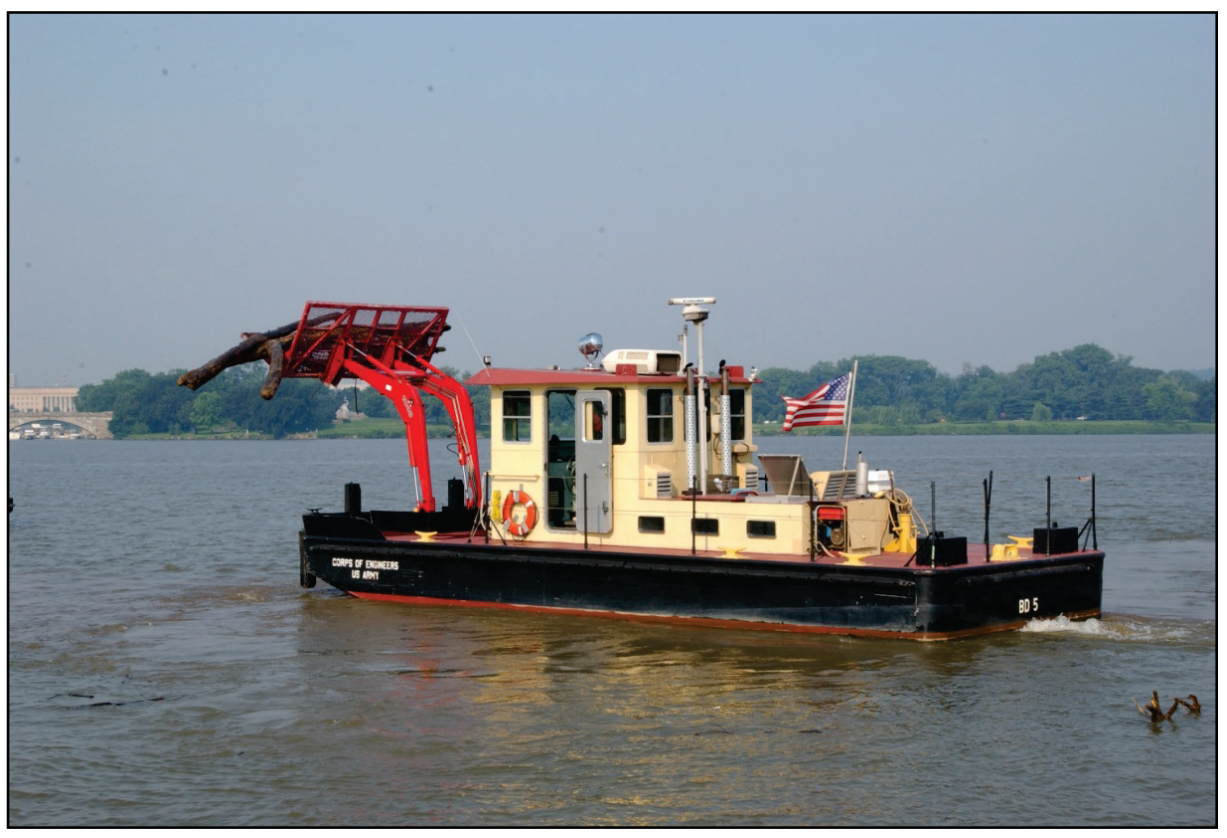

Figure 2. U.S. Army Engineer District St. Louis (MVS) towboat Pathfinder.

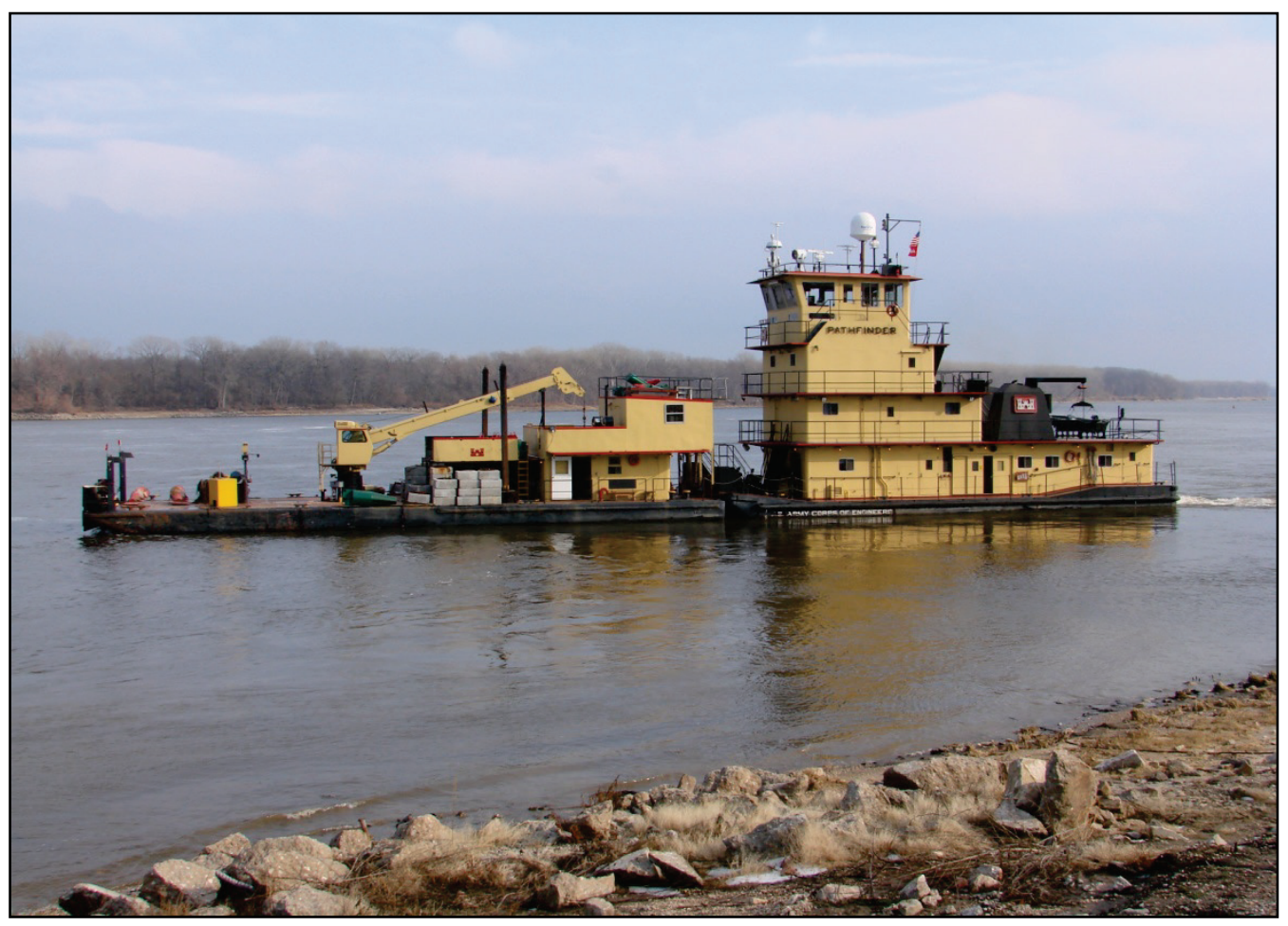


Figure 3. U.S. Army Engineer District San Francisco (SPN) debris boat Raccoon.

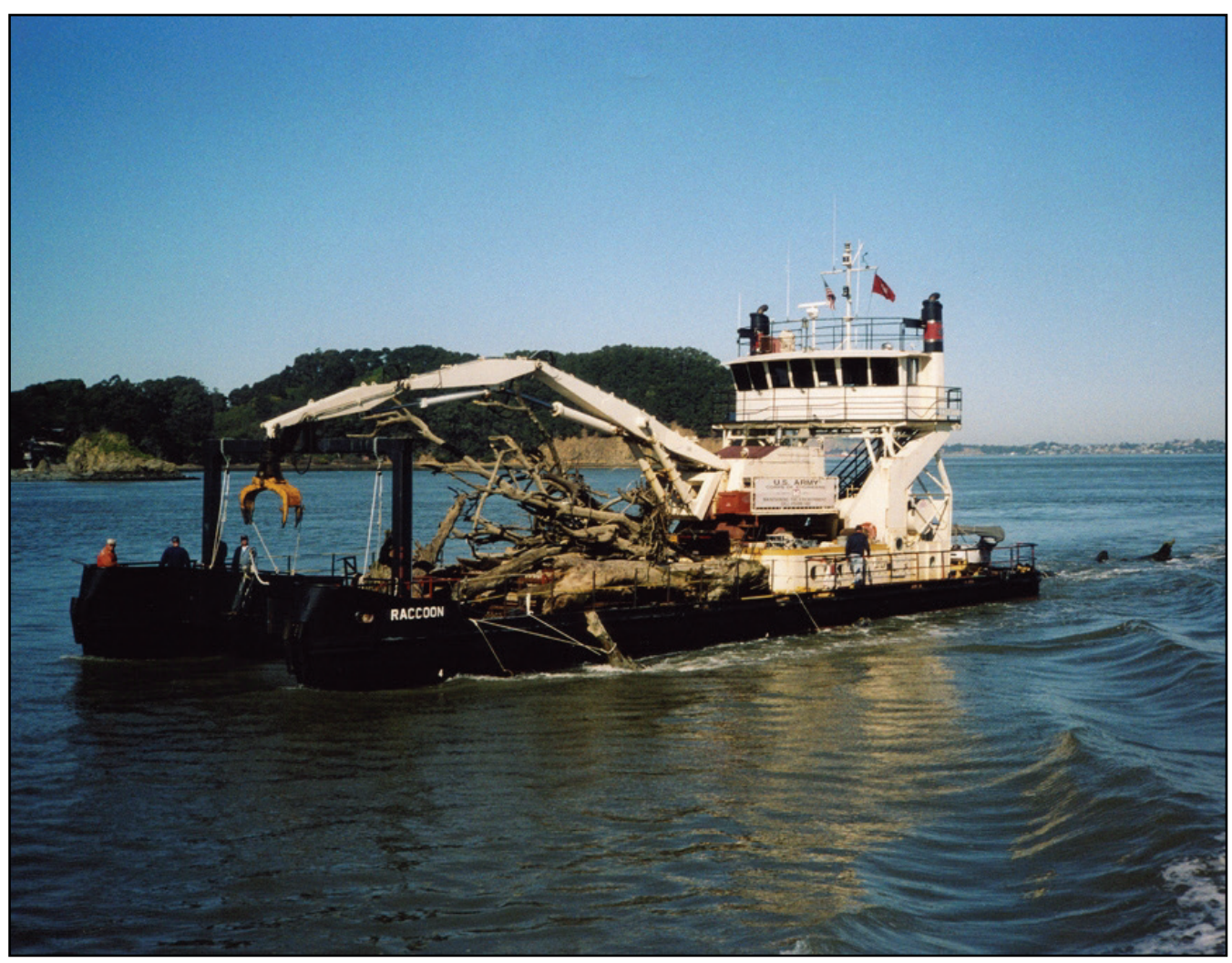

Figure 4. U.S. Army Engineer District Buffalo (LRB) tug Mike Donlon.

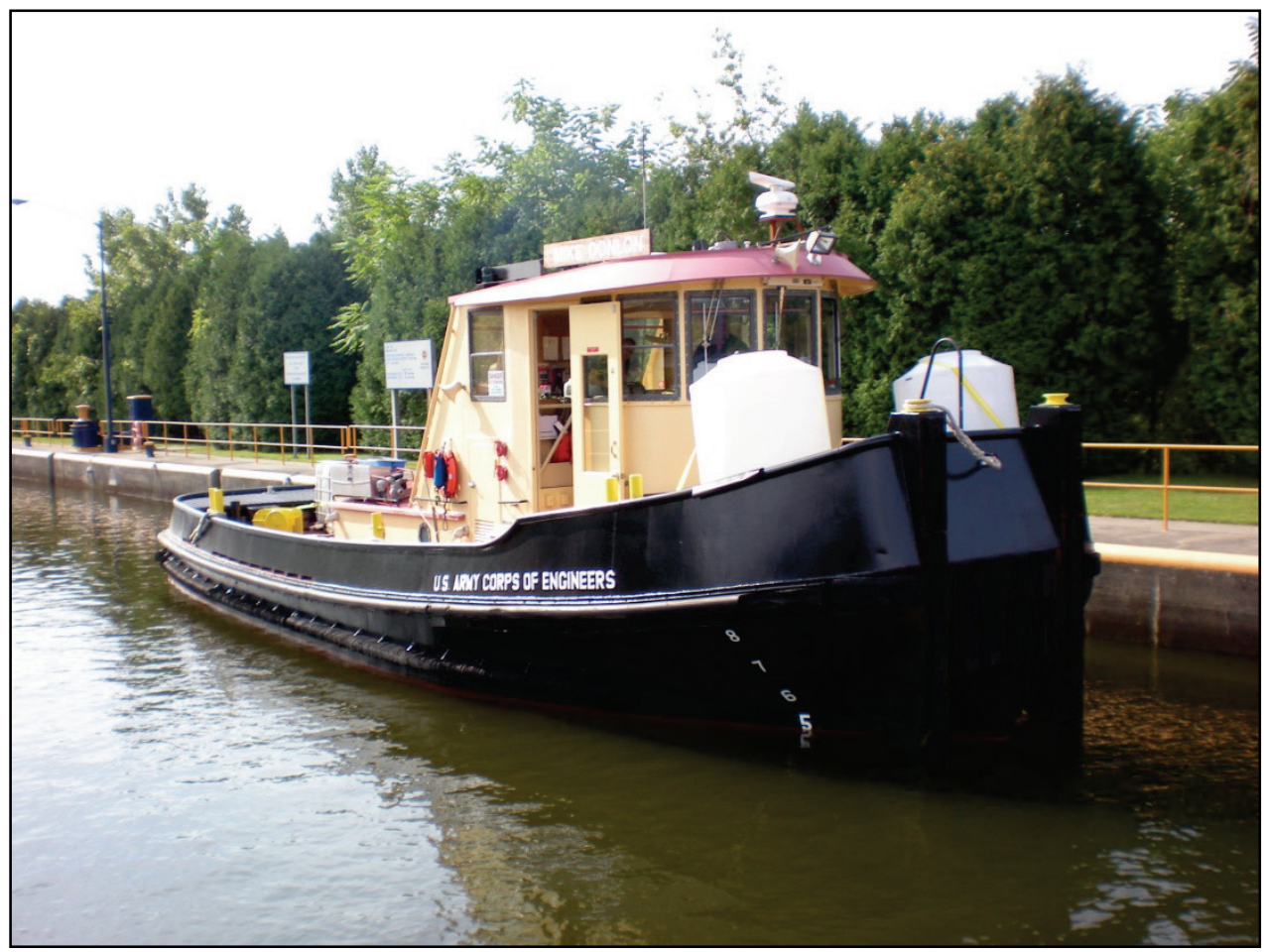


It was initially expected that cold flow properties would not be an issue for the USACE tests, but temperature concerns expressed by several biodiesel suppliers delayed fueling and field testing at several sites while waiting for warmer weather. Due to the external fuel tanks on the Raccoon, tank heaters were installed to mitigate potential cold weather flow properties.

LMFS has never had any kind of OEM failure or maintenance issue with an engine due to material compatibility issues. Overall, LMFS experience is that good vessel housekeeping will help ensure successful biodiesel usage; however, because of the potential biodiesel compatibility issues, the various Districts were advised to have engine condition assessments conducted before proceeding with the field demonstrations. The following items were recommended for inspection with the condition to be noted if acceptable, and if questionable, the component should be noted and repair or replacement should be considered:

- injectors

- valves, especially exhaust valves

- fuel lines, hoses, and seals.

In addition, it was recommended that new 10-micron fuel filters be installed and changed more frequently than was done when using No. 2 diesel.

The monitoring plan, as it applied to the evaluation study, called for working with the vessel operators to ensure that the areas of concern and the recommended inspections were understood and that any issues that arose were communicated to the study management. The cold-flow properties of biodiesel elicited the only significant concerns and were addressed by the delays for warmer weather and the heat pads that were installed on the Raccoon fuel tanks. Testing of the properties of the B10o supplied for the evaluation study were part of the monitoring plan. Fuel properties and costs were monitored in the evaluation study. Samples of biodiesel were analyzed and compared to the ASTM D6751 specifications. The different biodiesel fuel costs that were charged to the various Districts during the study were recorded.

Performance and emissions tests were a major part of the study monitoring plan. The fuel performance tests consisted of the run test and the push test. For the run test, the vessel was operated at a normal (constant) power level (set revolutions per minute [RPM]) over a water 
course selected to reduce hydrodynamic variability (currents and waves) as much as possible. This run test was conducted a minimum of three times each for operation using B10O and operation using No. 2 diesel. Run times, RPM, fuel consumption rates (gallons per hour [gph]), and total fuel consumption on each engine are recorded for each test. RPM are recorded from the engine management systems of the respective vessels. To measure fuel consumption rates, FlowScan fuel flow interface meters were installed on each propulsion engine. These meters combine a digital LCD engine hour meter, tachometer, fuel flowmeter, and fuel totalizer in a single instrument display that fits the panel space of a standard tachometer. These meters incorporate a two-stage adjustable calibration of gallons per hour and gallons used for increased accuracy (reportedly within $\pm 3 \%$ accuracy) and incorporate a momentary ON / constant OFF toggle button switch for resetting fuel totalizer readings. Figure 5 shows the various FlowScan system components set up in the Raccoon's engine room on the starboard engine.

Figure 5. Raccoon starboard propulsion engine (A) with FlowScan fuel-flow interface meter components, (B) fuel consumption LCD readout, and (C) fuel-line flow meter (one installed on the fuel supply line and one installed on the fuel return line).

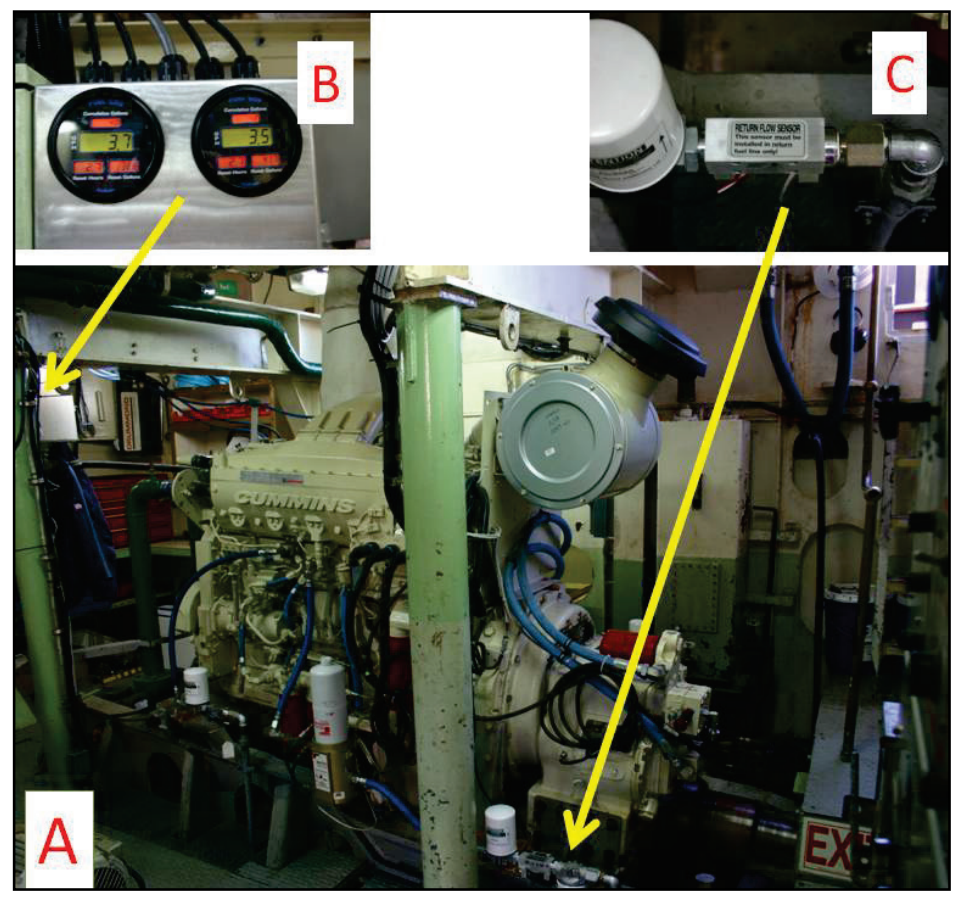


Each set of tests was performed while operating the engines on No. 2 diesel and then run again when the engines were operating on biodiesel. All tests were performed with engines at normal operating temperatures. Test conditions (wind, weather, etc.) were also recorded to duplicate conditions as closely as possible for each test.

The push test consisted of the vessel nosing up to a structure and pushing for 5 min at a steady RPM setting. Three settings were evaluated: minimum RPM (knuckled-in), mid-range RPM, and maximum RPM. These three RPM settings were performed three times each, and RPM, fuel consumption, and total fuel consumption on each engine recorded for each 5 min test. Similar to the run tests, these trials were conducted with the engines running on B100 and with them running on No. 2 diesel in the same locations, under as similar conditions as possible. Figure 6 shows the Mike Donlon conducting a push test in the Cleveland Ohio Harbor. Emissions of $\mathrm{CO}_{2}$ (calculated from measured oxygen, $\mathrm{O}_{2}$, emissions), $\mathrm{NO}_{\mathrm{x}}$, and $\mathrm{CO}$ were monitored during the push tests using a Testo 350XL portable emissions analyzer.

Figure 6. The Mike Donlon conducting a push test.

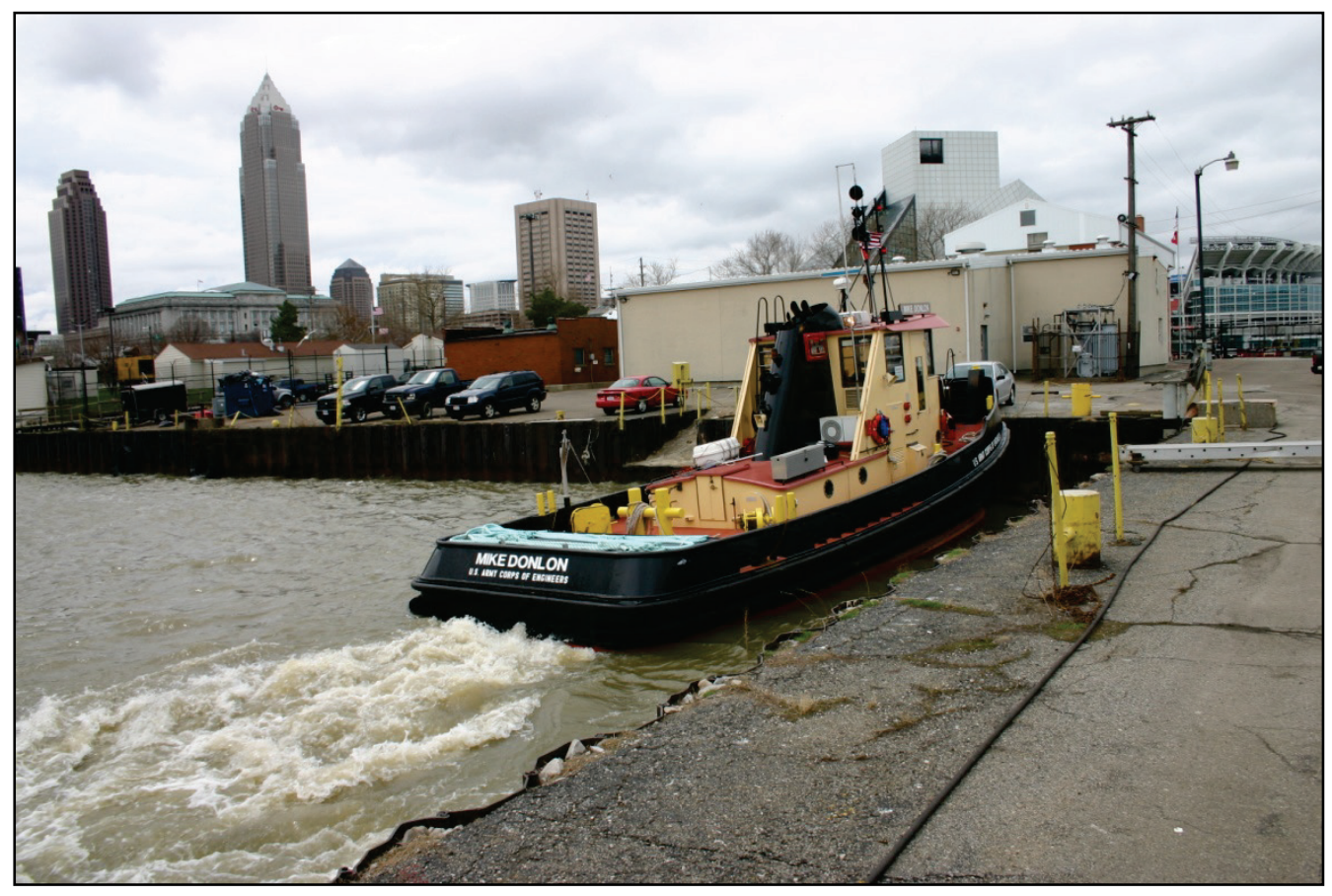

\section{Pretrial assessment and action plan}

The pretrial assessments were conducted by the various Districts. The $B D$ 5 had her fuel tanks cleaned specifically for the evaluation study. The 
Raccoon installed the four 1000-watt Arctic Fox pad-heaters to the bottom of each of their external 600-gallon fuel tanks. The heaters required significant electrical upgrades including a new sub panel in the engine room. These heaters are automatically controlled by thermostats. New 10micron filters were installed on all four vessels, and the Pathfinder had new fuel injectors installed on her starboard engines.

The samples of the biodiesel fuels supplied for each vessel were sent for testing and compared to the ASTM D6751 specifications (Appendix B). (The individual test reports are in Appendix C.) The specifications were all met, with the exception of the cetane number. The cetane number is a measure of the ignition delay, the time from fuel injection into the combustion chamber to ignition. Higher cetane numbers are believed to provide easier starting and quieter operation. More complete combustion and lower peak temperatures associated with higher cetane numbers are also thought to be responsible for lower $\mathrm{NO}_{\mathrm{x}}$ emissions. ASTM D6751 calls for a minimum cetane number of 47. The test results for the Mike Donlon and Pathfinder were 46.2 and 44, respectively. The fuels for the Raccoon and $B D-5$ had cetane numbers of 48 and 55 , respectively. The fuel test results were only available after the evaluation study.

The Mike Donlon and Raccoon did not experience any observable impacts due to material compatibility issues. The Pathfinder and the $B D-5$ experienced significant degradation to fuel hoses. Several of the Pathfinder's degraded fuel hoses that experienced significant degradation are shown in Figure 7. The hoses were replaced.

In another incident, the Raccoon was topped off with $\mathrm{B} 100$ and, after leaving the dock, experienced engine problems. Multiple fuel filters had to be replaced to keep the engines running. Inspection of the fuel filters revealed that they were coated with a jelly-like substance. The fuel provider pumped out the fuel tanks and replenished them with ULSD. After running several tank-loads of ULSD with no noticeable adverse effects on engine performance, the Raccoon resumed using B20. No other mechanical issues resulting from using B10o were encountered. There were no other negative experiences noted by the vessel crews and management, and the general consensus of the floating plant operators was favorable. 
Figure 7. Fuel hoses degraded by B100.

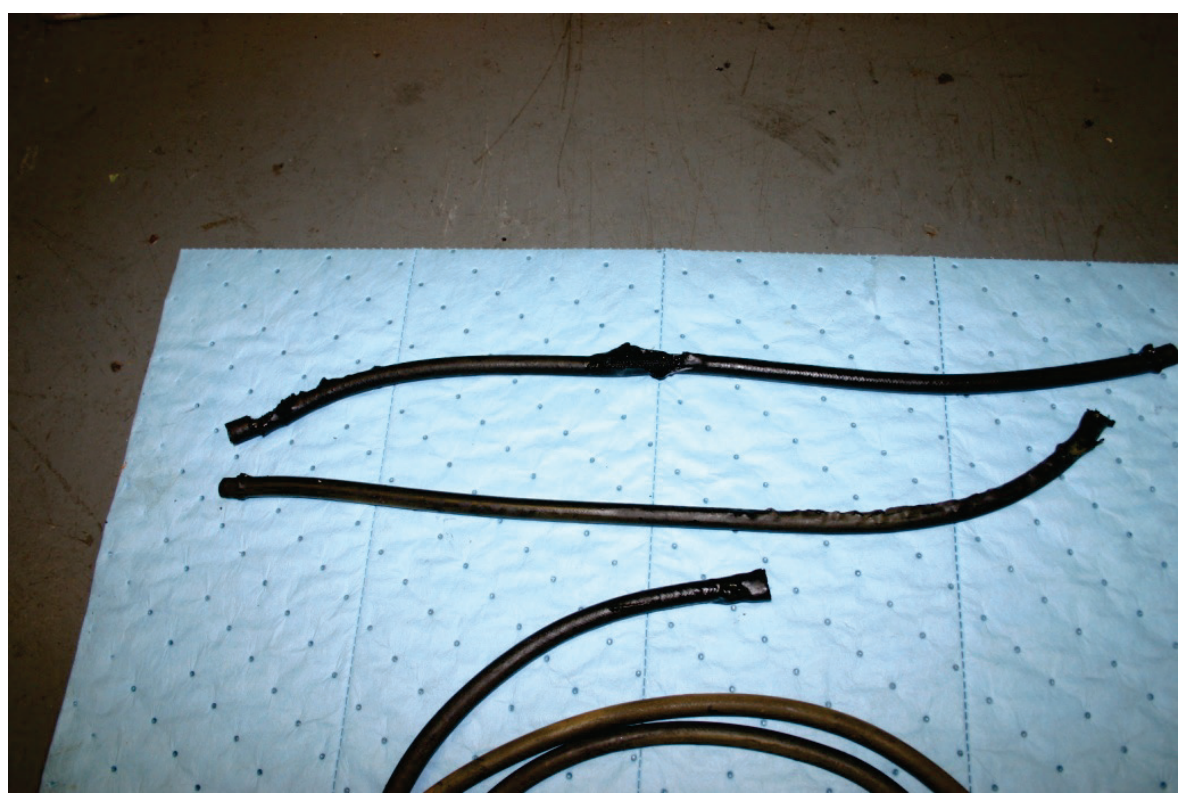




\section{Evaluation Study Results and Assessment}

\section{Fuel consumption}

The fuel consumption results for the run tests are listed in Table 2.

Table 2. Average B100 fuel consumption compared to No.2 diesel fuel consumption for the run tests (positive numbers indicate increased B100 consumption and negative numbers indicated lower B100 consumption).

\begin{tabular}{|l|c|c|c|}
\hline Engine & $\begin{array}{l}\text { Pathfinder } \\
\text { (\% difference) }\end{array}$ & $\begin{array}{l}\text { Raccoon } \\
\text { (\% difference) }\end{array}$ & $\begin{array}{l}\text { Mike Donlon } \\
\text { (\% difference) }\end{array}$ \\
\hline Port & 4.8 & -11.0 & -1.0 \\
\hline Starboard & -3.9 & -9.4 & -1.2 \\
\hline
\end{tabular}

Table 2 does not include the results for the $B D-5$ because of problems with the FlowScans. The average gallons per hour fuel consumption rate increased for the Pathfinder's port engine when using biodiesel and decreased for its starboard engine. The average gallons per hour fuel consumption decreased when using biodiesel for both the port and starboard engines of the Mike Donlon and Raccoon.

Fuel consumption results for the push tests are listed in Table 3. Table 3 also does not include the results for the $B D-5$ because of problems with the FlowScans. Table 3 shows that the B10o fuel consumption was greater than the No. 2 diesel fuel consumption for the Pathfinder at low and midrange RPM. At mid-range RPM, B10o fuel consumption was greater for the Raccoon's port engine and the same for the Raccoon's starboard engine. For all other cases, Table 3 lists results that indicate the B1oo fuel consumption was less than No. 2 diesel fuel consumption.

Table 3. Average B100 fuel consumption compared to No.2 diesel fuel consumption for the push tests (positive numbers indicate increased B100 consumption and negative numbers indicated lower B100 consumption).

\begin{tabular}{|l|c|c|c|}
\hline Vessel & $\begin{array}{c}\text { Low RPM } \\
\text { (\% difference) } \\
\text { Port Starboard }\end{array}$ & $\begin{array}{c}\text { Mid-Range RPM } \\
\text { (\% difference) } \\
\text { Port Starboard }\end{array}$ & $\begin{array}{c}\text { High RPM } \\
\text { (\% difference) } \\
\text { Port Starboard }\end{array}$ \\
\hline Pathfinder & 5.52 .8 & 2.510 .0 & $-7.4-8.0$ \\
\hline Raccoon & $-17.9-16.3$ & 5.40 .0 & $-6.3-6.3$ \\
\hline Mike Donlon & $-21.4-21.4$ & $-35.2-31.8$ & $-1.0-9.4$ \\
\hline
\end{tabular}


Interpreting these results is complicated because the load points were set based on RPM and not engine power which is a function of the torque on the shaft, and because the rate at which the fuel pumps deliver fuel to the engine is also a function of engine RPM. However, it can be said that since B10o has an approximately $7 \%$ to $10 \%$ lower energy content per gallon than No. 2 diesel, a lesser fuel consumption at the same RPM when using B100 is unexpected, and lesser amounts of $20 \%$ to $30 \%$ point to insufficiently accurate measurements. LMFS was unable to measure a decrease in power due to the lower energy content of B10o. This may have been due to field testing on a vessel in a dynamic (fluid) environment with constantly varied engine loads, lack of adequate sensitivity in the measuring instruments, or the higher cetane, lubricity, and cleanliness levels of B10o. What was demonstrated is that for LMFS field tests, there was no noticeable operational difference in terms of vessel power between B100 and diesel.

\section{Emissions}

The results of the emissions monitoring of $\mathrm{CO}, \mathrm{NO}_{\mathrm{x}}$, and $\mathrm{CO}_{2}$ (calculated from measured oxygen, $\mathrm{O}_{2}$, emissions) are shown in Figures 8 through 10 and listed in Table 4. In the figures, the B100 is designated as the candidate fuel, and the No. 2 diesel is the baseline fuel. Because of erroneous settings used to monitor the Raccoon, emissions were only analyzed for the $B D-5$, Pathfinder, and Mike Donlon. The plan called for each RPM setting to be monitored three times with only the port engine engaged and three times with only the starboard engine engaged. Due to operational problems, some settings had data for only two tests. Additional tests were conducted in cases where there were questions of valid data recording, a total of seven times at one RPM setting. In one case, with the Pathfinder starboard engine at low RPM using biodiesel, the data showed values clearly outside normal ranges, and they were not included in the analysis.

The data for $\mathrm{CO}_{2}$ are plotted in Figures 8, 9, and 10.They show $\mathrm{CO}_{2}$ emissions rising rapidly up to 10 to $15 \mathrm{sec}$ into the test and then rising slightly until the end of the test at $60 \mathrm{sec}$. In the case of $\mathrm{CO}_{2}$, the results for high, medium, and low RPM separate into three distinct regions in the plots. This was not generally true for $\mathrm{CO}$ and $\mathrm{NO}_{\mathrm{x}}$, as shown in Figure 11, where a plot of the $\mathrm{NO}_{\mathrm{x}}$ data for the Pathfinder port engine shows results that cannot be clearly distinguished for each RPM setting. As a result, a complete set of plots is presented for $\mathrm{CO}_{2}$ only. 
Figure 8. $\mathrm{CO}_{2}$ emissions for the $B D-5$.

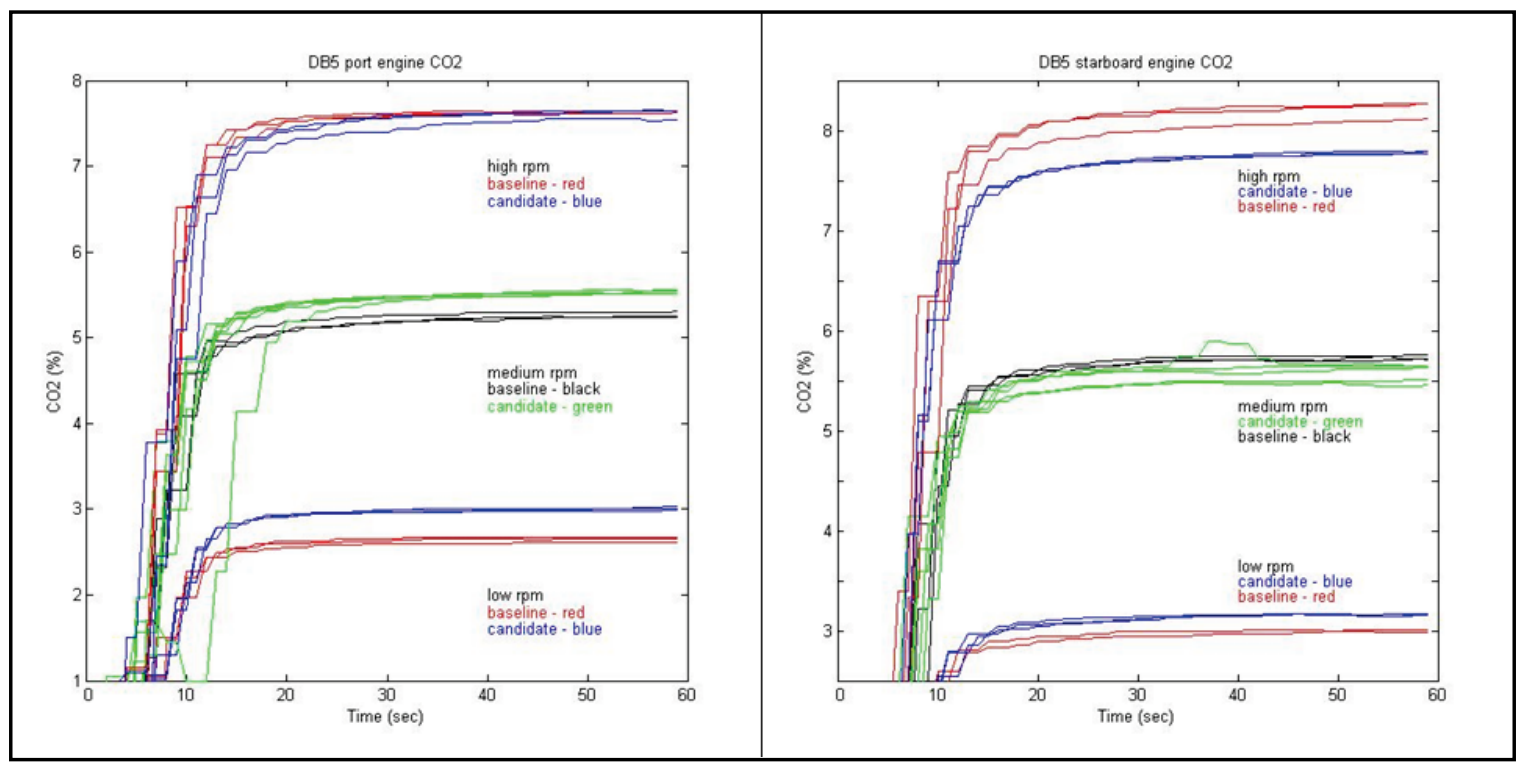

Figure 9. $\mathrm{CO}_{2}$ emissions for the Pathfinder.

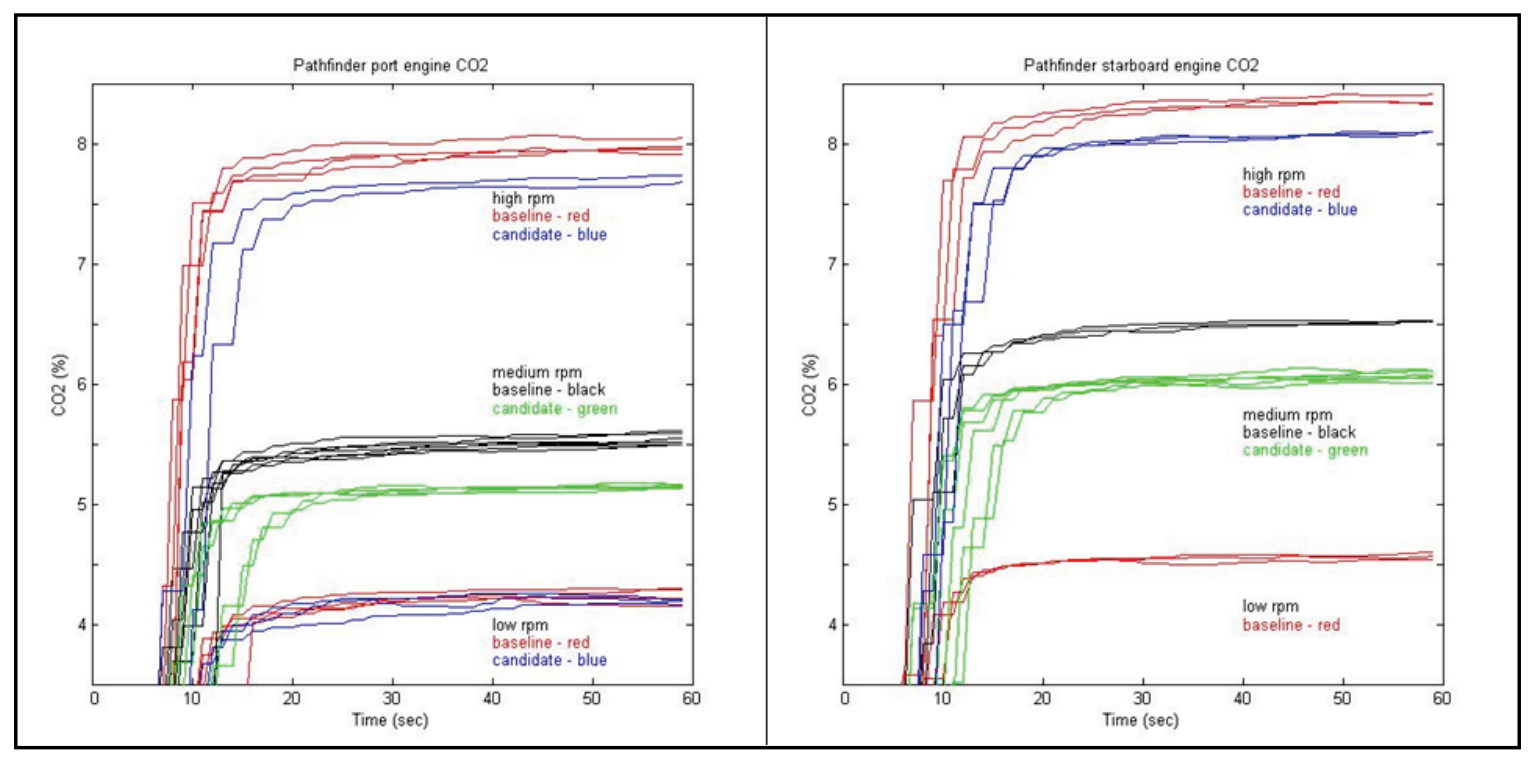


Figure 10. $\mathrm{CO}_{2}$ emissions for the Mike Donlon.

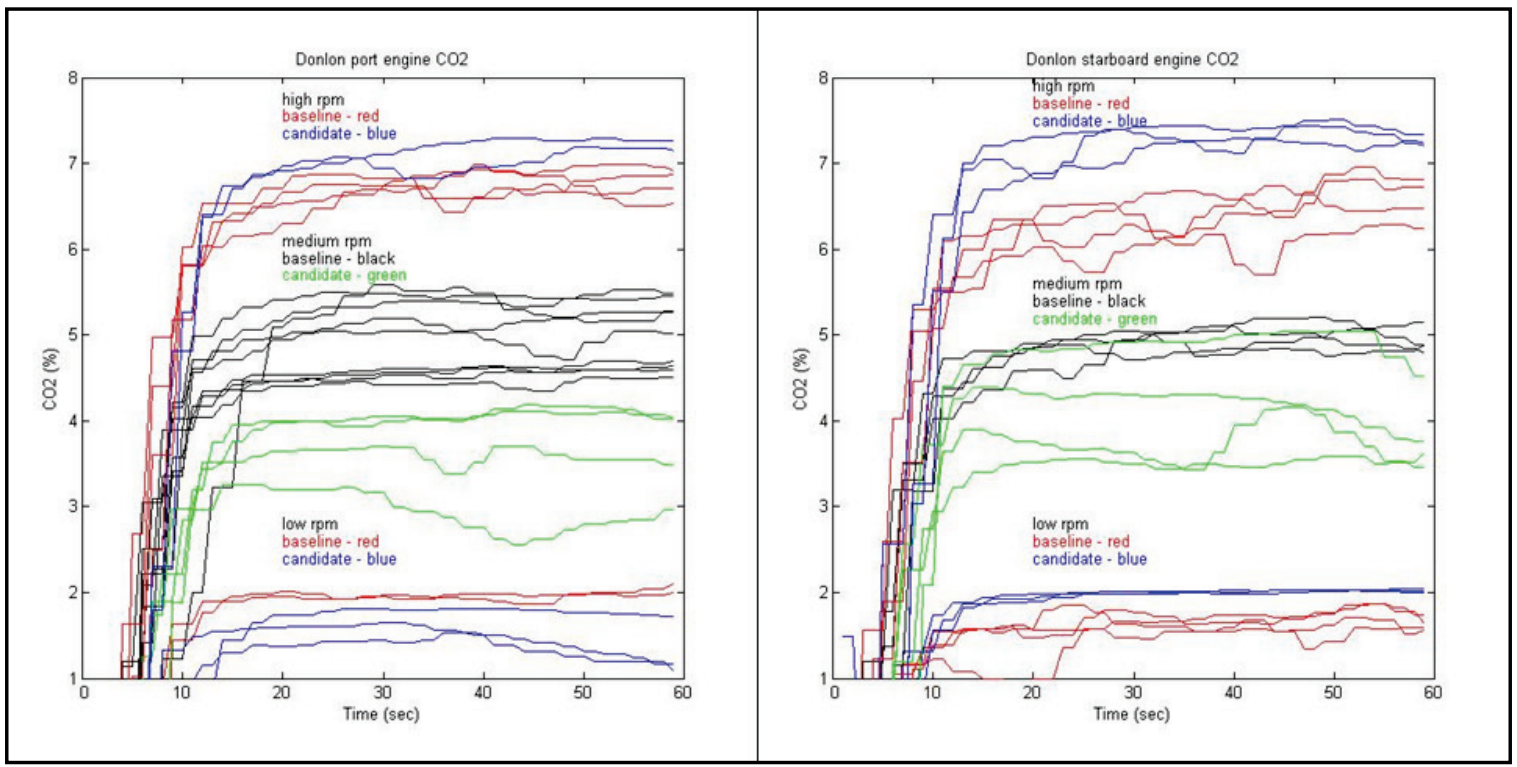

Table 4. Average emissions values (D - No. 2 diesel and B - B100) of the port and starboard engines. Units are percent volume for $\mathrm{CO}_{2}$ and ppm for $\mathrm{CO}$ and $\mathrm{NO}_{\mathrm{x}}$.

\begin{tabular}{|l|l|l|l|l|l|l|l|}
\hline \multirow{2}{*}{ Parameter } & \multicolumn{2}{c|}{ BD-5 } & \multicolumn{2}{c|}{ Pathfinder } & \multicolumn{2}{c|}{ Mike Donlon } \\
\cline { 2 - 8 } & \multicolumn{6}{|c|}{ B } & \multicolumn{2}{c|}{ D } & \multicolumn{2}{c|}{ B } & \multicolumn{1}{c|}{ D } & \multicolumn{1}{c|}{ B } \\
\hline Low RPM & 2.81 & 3.06 & 4.39 & 4.17 & 1.80 & 1.77 \\
\hline Mid-range RPM & 5.47 & 5.53 & 6.00 & 5.58 & 4.74 & 3.87 \\
\hline High RPM & 7.88 & 7.64 & 8.12 & 7.86 & 6.56 & 7.20 \\
\hline \multicolumn{7}{|c|}{ NOx } \\
\hline Low RPM & 929 & 807 & 1865 & 1477 & 244 & 216 \\
\hline Mid-range RPM & 1113 & 1008 & 1964 & 1859 & 869 & 677 \\
\hline High RPM & 1204 & 1223 & 1362 & 1771 & 1879 & 2317 \\
\hline \multicolumn{7}{|c|}{ CO } \\
\hline Low RPM & 167 & 298 & 354 & 557 & 87 & 166 \\
\hline Mid-range RPM & 140 & 179 & 405 & 608 & 64 & 66 \\
\hline High RPM & 85 & 86 & 482 & 205 & 75 & 57 \\
\hline
\end{tabular}


Figure 11. Pathfinder port engine $\mathrm{NO}_{\mathrm{x}}$ emissions.

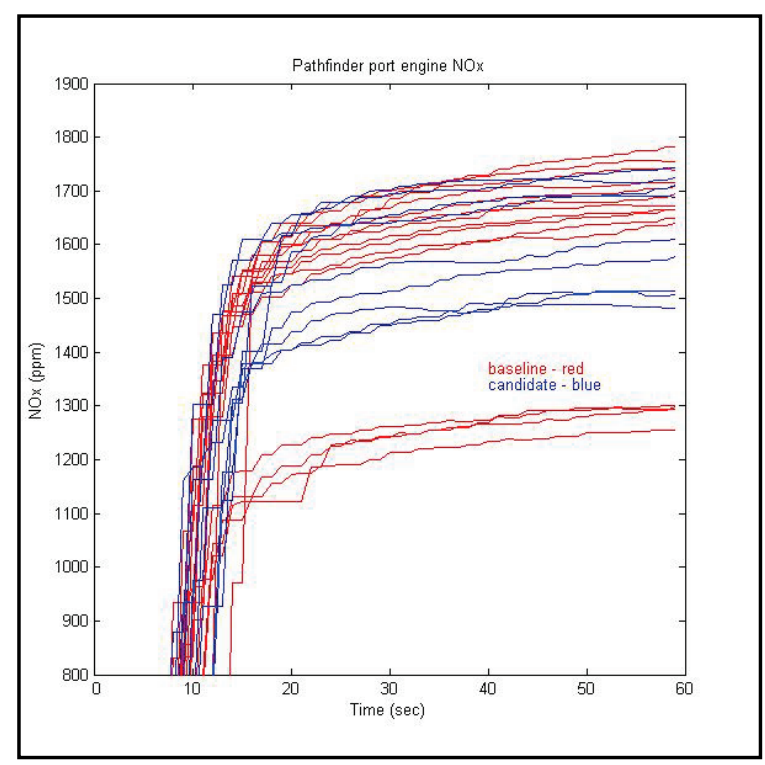

Table 4 lists the average of the port and starboard engine emissions for the last 30 sec of the tests for each vessel engine and RPM setting. The average for $\mathrm{CO}_{2}$ when using diesel at low and medium RPM is higher for one vessel, lower for one vessel, and approximately the same for the third vessel. At high RPM, the average $\mathrm{CO}_{2}$ emissions is higher when using diesel for two vessels and is lower for the third vessel. Table 4 presents higher $\mathrm{CO}$ emissions for biodiesel than diesel at low and medium RPM in all cases. At high RPM, the $\mathrm{CO}$ emissions are higher for regular diesel than for biodiesel for two vessels, and for one vessel are nearly equal. Table 4 shows $\mathrm{NO}_{\mathrm{x}}$ emissions are higher for diesel than for biodiesel at low and medium RPM in all cases. At high RPM, the $\mathrm{NO}_{\mathrm{x}}$ emissions are higher for biodiesel than for diesel in all cases.

\section{Operational performance}

The Pathfinder used B100 from March 2011 to November 2011, and the $B D-5$ continued using B100 after the evaluation study and is still using it. None of the four vessels in the evaluation study had any serious mechanical problems attributable to using B10o. The Pathfinder and the $B D-5$ experienced fuel hose incompatibility degradation as a result of using biodiesel. However, after replacing the hoses, neither had any more problems with material degradation. The $B D-5$ does replace its fuel filters more often now than it did when it was using No. 2 diesel. With the exception of the previously described problem of the Raccoon's gelled fuel tanks, there were no other issues related to engine power or efficiency, and 
there were no negative effects on routine vessel operations. The $B D-5$ has been using $\mathrm{B} 100$ for three winters in Washington, DC, and has not experienced any cold-flow problems. It is interesting to note that when the Raccoon filled up with \# 2 diesel to investigate potential performance impacts due to returning to diesel fuel from biodiesel use, no noticeable impacts were observed. In general, the crews of all the vessels were favorably impressed with the reduction in soot and the overall improved cleanliness that came with using biodiesel.

Biodiesel prices vary across the country and tend to be "slightly higher" than those for petroleum diesel (DOE 2014). While this was generally the case during the study, there were instances where the B100 was less expensive than ultra-low sulfur diesel (ULSD). For example, when the Raccoon switched from B100 to ULSD and then went back to B10o to investigate potential effects of changing fuels, costs varied as listed in Table 5 .

Table 5. Raccoon diesel costs.

\begin{tabular}{|c|c|c|c|c|c|}
\hline Vessel & Fueling Date & $\begin{array}{l}\text { Biodiesel } \\
\text { Gallons } \\
\text { Loaded } \\
\text { (L) }\end{array}$ & $\begin{array}{l}\text { Biodiesel Cost } \\
\text { per Gallon } \\
\text { (At Dock) }\end{array}$ & $\begin{array}{l}\text { No. } 2 \text { Diesel } \\
\text { Gallons Loaded } \\
\text { (L) }\end{array}$ & $\begin{array}{l}\text { No. } 2 \text { Diesel } \\
\text { Cost per Gallon } \\
\text { (At Dock) }\end{array}$ \\
\hline \multirow{3}{*}{ Raccoon } & 24 Mar 2011 & $700(2650)$ & $\$ 3.65$ & \multirow{3}{*}{648 (2453) } & \multirow{3}{*}{$\$ 3.95$} \\
\hline & 30 Mar 2011 & & & & \\
\hline & 21 Apr 2011 & 750 (2839) & $\$ 3.92$ & & \\
\hline
\end{tabular}

The fuel price differences of the other vessels also varied with location, but through developing a relationship with a local or regional fuel supplier, these differences can potentially be significantly reduced. The LMFS reported that they were able to negotiate contracts that provided B99.9 at a lower price than No. 2 diesel. 


\section{Expanded Operational Experience and Improved Testing of Emissions and Fuel Consumption}

Successful results from the evaluation study led to an expanded study to evaluate biodiesel fuel usage in an increased number and more diverse types of vessels. In addition to retaining the Raccoon, Pathfinder, and BD5, the additional vessels included a dustpan dredge, a hopper dredge, three towboats, three crane barges, a crew boat, and another debris-removal vessel as listed and shown in Appendix A.

The types of biodiesel used in these vessels ranged from $\mathrm{B}_{5}$ to $\mathrm{B} 100$, and there was also an opportunity to test a second-generation biodiesel fuel. In the earlier tests, the Raccoon based in California used ULSD with properties based on standards set by the California Air Resources Board (CARB), whereas the other vessels used federal ULSD with properties based on U.S. Environmental Protection Agency (EPA) standards. The second generation biodiesel tested was Solazyme fuel oil (produced from algal oils). The properties of the various fuels are listed in Table 6.

Table 6. Fuel properties.

\begin{tabular}{|c|c|c|c|}
\hline Fuel Type & Density $\left(\mathrm{kg} / \mathrm{m}^{3}\right)$ & $\begin{array}{l}\text { Carbon Content (\% by } \\
\text { weight) }\end{array}$ & Cetane Number \\
\hline Federal ULSD & 835.9 & 86.51 & 46 \\
\hline CARB ULSD & 835.9 & 86.51 & 51 \\
\hline Solazyme & 806.5 & 85.47 & 75 \\
\hline B100 & 890.0 & 77.0 & 50 \\
\hline
\end{tabular}

Due to its lower density, Solazyme and B10o have approximately the same energy content by volume. The main difference between Solazyme and the other fuels is its higher cetane number. The more complete combustion and lower peak temperatures associated with higher cetane numbers result in lower $\mathrm{NO}_{\mathrm{x}}$ emissions (Velmurugan and Gowthamn 2012). Higher fuel densities have been found to produce higher $\mathrm{NO}_{\mathrm{x}}$ emissions (McCormack 2001). 
While the expanded study involved using biodiesel on 14 USACE vessels, there were differing levels of monitoring applied on different vessels. The most basic level of evaluation consisted of using biodiesel during normal operations and surveying the crew regarding their opinion on its operational suitability (e.g., delivered power, engine condition). This level was applied onboard the Prairie du Rocher, Derrick No. 6, Kimmswick, Pathfinder, Barron, Fisher, and Sewell. The next higher level of monitoring included the basic level previously described, in addition to the installation of the (previously described) FlowScan fuel-flow measuring system to monitor and record fuel consumption. An improvement to the FlowScan system used in the initial study consisted of the addition of an NMEA200o Interface that allowed a variety of fuel parameters (gallons per hour, gallons consumed, gallons remaining, nautical miles per gallon, and distance to empty) to be displayed on a video screen that was typically installed on the bridge. This capability was installed aboard the BD-6, Yaquina, Grandtower, Potter, and Raccoon. (A screen shot is shown in Figure 12.)

Figure 12. Output of NMEA2000 Interface to FlowScan fuel-flow monitoring system.

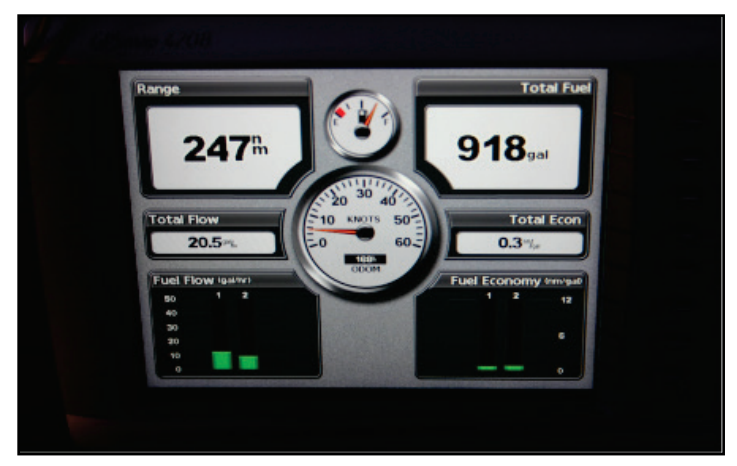

The improved emissions monitoring (compared to the initial study) was the highest level of monitoring. It was conducted onboard the Raccoon and the $B D-5$. For the emissions testing, a team consisting of the USACE, the Bristol Harbor Group, and the University of California, Riverside, was formed. The Bristol Harbor Group, a naval architecture and marine engineering company located in Bristol, RI, was responsible for measurements of engine power and fuel consumption. The University of California, Riverside, Center for Environmental Research and Technology (CERT), part of the Bourns College of Engineering, conducts research in atmospheric processes, emissions from next-generation technologies and fuels, sustainable fuels, transportation systems, and solar energy, and was 
responsible for developing the test strategy, making the emissions measurements, and data analysis and reporting.

\section{Emissions and fuel consumption test procedures}

Like the case for the evaluation study, the improved tests on the $B D-5$ and Raccoon were conducted by having the vessels push against a bulkhead. The emissions sampling instrumentation was connected directly to the exhaust stacks (Figure 13).

Figure 13. Emissions testing instrumentation connected directly into the exhaust stack on the $B D-5$.

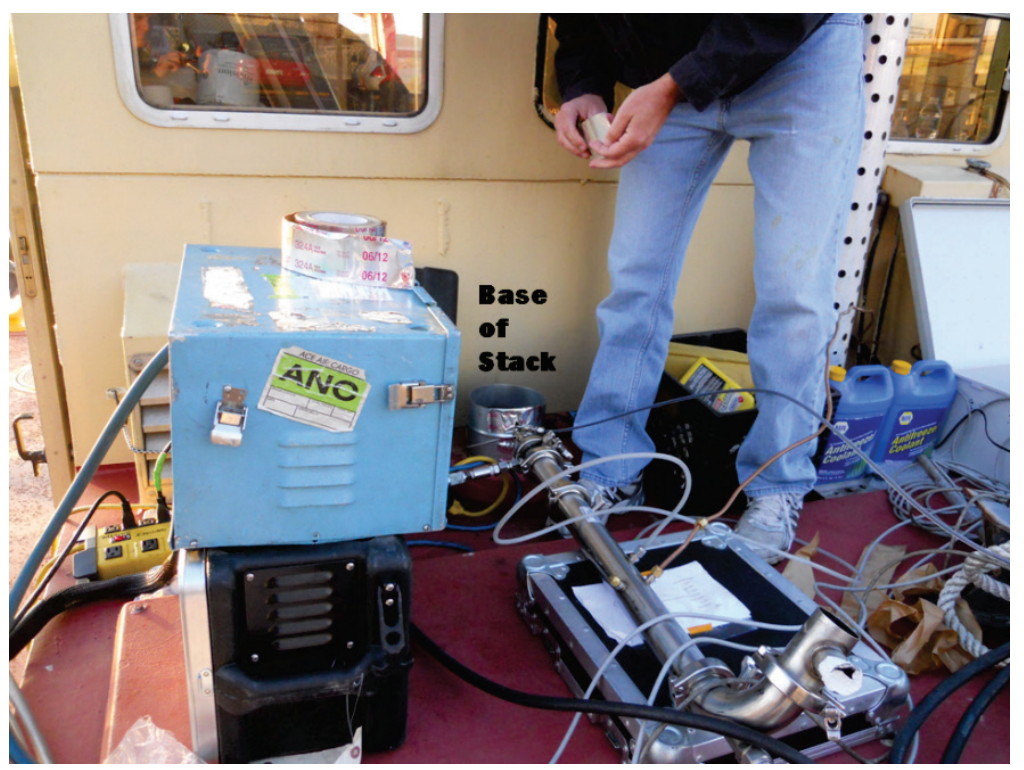

Emissions were measured while the vessels operated at target loads of $25 \%, 50 \%, 75 \%$, and $100 \%$, based on performance when using B100. Basing the loads on performance using B100 was chosen because, with its lower energy content, it was anticipated that $100 \%$ load using No. 2 diesel could not be achieved when using B10o. Gaseous emissions of $\mathrm{CO}_{2}, \mathrm{CO}$, and $\mathrm{NO}_{\mathrm{x}}$ were measured by a HORIBA Portable Gas Analyzer (PG-250). Measurements of the mass of particulate matter with sizes of 2.5 microns or less $\left(\mathrm{PM}_{2.5}\right)$ were made by extracting samples of raw exhaust and drawing them through a 2.5 micron cyclone separator and Teflon and quartz filters. The filters were placed in individual containers and taken to a laboratory where they were analyzed for total $\mathrm{PM}_{2.5}$ mass and for elemental carbon (EC) and organic carbon (OC). Additionally, for the Raccoon, a fast-scanning mobility particle sizer (F-SMPS) was used to measure particle size distributions. 
To calculate emissions factors, accurate measurements of exhaust flow rates were needed. The more modern engines on the Raccoon have electronic control modules (ECM), and it was possible to use them to provide data for rpm, power, fuel consumption, and the boost pressure and temperature for the intake air. With the ECM data for the intake air, the exhaust flow rates for the Raccoon could be determined using the carbon balance method. The carbon balance method assumes all carbon in the fuel is burned, so the concentration of $\mathrm{CO}_{2}$ in the exhaust, and the fuel flow rate, determine the exhaust flow rate. For the $B D-5$, a turbine flow meter installed on the air intake provided a direct measurement of the exhaust flow.

To provide consistent data methodologies for engine power and fuel consumption on the Raccoon and $B D-5$, Bristol installed fuel-flow meters, strain gauges, and rpm monitors to the engine shafts of the vessels. The strain gauges were bonded to the drive shafts and measured torque. Engine power was calculated from the measured torque and the rpm measurements were made from the magnetic sensors attached to the shafts. Fuel consumption measurements were made using FlowScan Instrument Company, Inc., flow meters installed in the fuel supply and return lines.

Fuel consumption is the difference between the supply and return fuel rates.

\section{Emissions and fuel consumption test results}

For the Raccoon, unreferenced fuel consumptions (fc) and the brakespecific fuel consumptions (bsfc) are listed in Table 7. The unreferenced fuel consumptions versus engine power are plotted in Figure 14, and the brake-specific fuel consumptions at the target engine powers are plotted in Figure 15.

Table 7. Fuel consumption for the Raccoon.

\begin{tabular}{|c|c|c|c|c|c|c|c|c|}
\hline \multirow[b]{3}{*}{ Fuel Type } & \multicolumn{8}{|c|}{$\begin{array}{l}\text { Engine Load } \\
\text { (\% of maximum) }\end{array}$} \\
\hline & \multicolumn{2}{|c|}{$25 \%$} & \multicolumn{2}{|c|}{$50 \%$} & \multicolumn{2}{|c|}{$75 \%$} & \multicolumn{2}{|c|}{$100 \%$} \\
\hline & $\begin{array}{c}\mathrm{fc} \\
(\mathrm{kg} / \mathrm{hr})\end{array}$ & $\begin{array}{c}\text { bsfc } \\
(\mathrm{kg} / \mathrm{kWhr})\end{array}$ & $\begin{array}{c}\mathrm{fc} \\
(\mathrm{kg} / \mathrm{hr})\end{array}$ & $\begin{array}{c}\text { bsfc } \\
(\mathrm{kg} / \mathrm{kWhr})\end{array}$ & $\begin{array}{c}\text { fc } \\
(\mathrm{kg} / \mathrm{hr})\end{array}$ & $\begin{array}{c}\text { bsfc } \\
\text { (kg/kWhr) }\end{array}$ & $\begin{array}{c}\mathrm{fc} \\
(\mathrm{kg} / \mathrm{hr})\end{array}$ & $\begin{array}{c}\text { bsfc } \\
(\mathrm{kg} / \mathrm{kWhr})\end{array}$ \\
\hline B100 & 19.1 & 0.27 & 40.0 & 0.26 & 59.1 & 0.26 & 76.9 & 0.25 \\
\hline ULSD & 17.8 & 0.25 & 36.4 & 0.24 & 53.7 & 0.24 & 71.4 & 0.23 \\
\hline Solazyme & 18.2 & 0.25 & 37.1 & 0.24 & 53.8 & 0.24 & 71.9 & 0.23 \\
\hline
\end{tabular}


Figure 14. Fuel consumption versus engine power for the Raccoon.

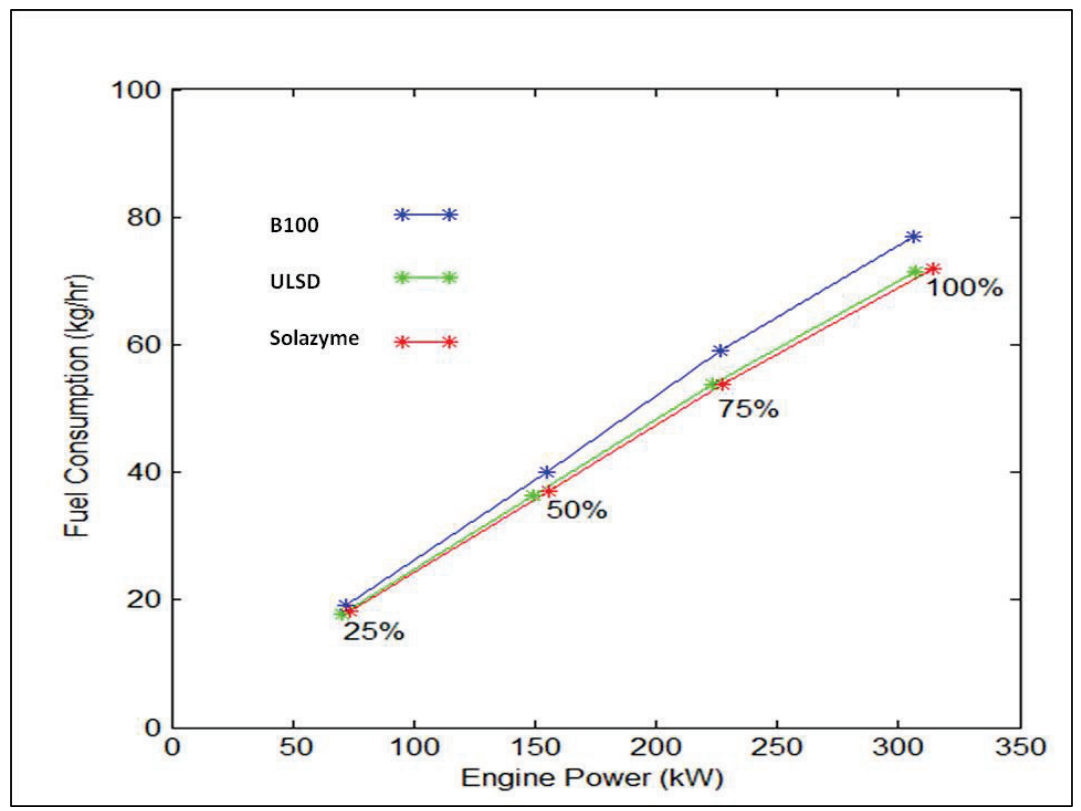

Figure 15. Brake-specific fuel consumption of B100 (blue), ULSD (green), and Solazyme (red) fuels for the Raccoon.

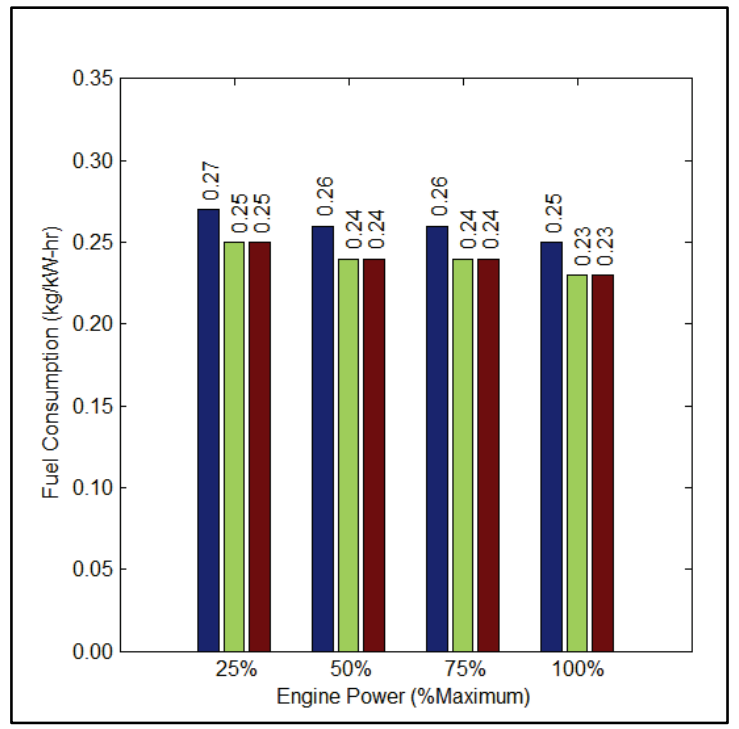

The emissions of $\mathrm{CO}_{2}, \mathrm{CO}$, and $\mathrm{NO}_{\mathrm{x}}$ for the Raccoon are listed in Table 8 and plotted in Figures 16 through 21. The $\mathrm{PM}_{2.5}$ emissions are listed in Table 9, and plotted in Figures 22 and 23. 
Table 8. Emissions of $\mathrm{CO}_{2}, \mathrm{CO}$, and $\mathrm{NO}_{x}$ for the Raccoon.

\begin{tabular}{|c|c|c|c|c|c|c|}
\hline $\begin{array}{l}\text { Engine Load } \\
\text { (\% of } \\
\text { maximum) }\end{array}$ & \multicolumn{2}{|c|}{$\begin{array}{l}\mathrm{CO}_{2} \text { Emissions } \\
(\mathrm{g} / \mathrm{hr})(\mathrm{g} / \mathrm{kWhr})\end{array}$} & \multicolumn{2}{|c|}{$\begin{array}{l}\text { CO Emissions } \\
\text { (g/hr) (g/kWhr) }\end{array}$} & \multicolumn{2}{|c|}{$\begin{array}{l}\text { NOx Emissions } \\
(\mathrm{g} / \mathrm{hr})(\mathrm{g} / \mathrm{kWhr})\end{array}$} \\
\hline \multicolumn{7}{|c|}{ B100 } \\
\hline 25 & 56,200 & 782 & 43 & 0.60 & 736 & 10.23 \\
\hline 50 & 117,703 & 758 & 257 & 1.65 & 1089 & 6.91 \\
\hline 75 & 174,076 & 767 & 266 & 1.18 & 1614 & 7.19 \\
\hline 100 & 226,713 & 741 & 708 & 2.32 & 1963 & 6.42 \\
\hline \multicolumn{7}{|c|}{ ULSD } \\
\hline 25 & 56,654 & 804 & 52 & 0.73 & 712 & 10.10 \\
\hline 50 & 115,776 & 778 & 298 & 2.00 & 1053 & 7.07 \\
\hline 75 & 170,938 & 765 & 408 & 1.83 & 1626 & 7.28 \\
\hline 100 & 227,320 & 741 & 856 & 2.79 & 1879 & 6.13 \\
\hline \multicolumn{7}{|c|}{ Solazyme } \\
\hline 25 & 57,271 & 781 & 55 & 0.75 & 693 & 9.45 \\
\hline 50 & 116,500 & 750 & 343 & 2.21 & 982 & 6.32 \\
\hline 75 & 169,041 & 744 & 415 & 1.83 & 1541 & 6.78 \\
\hline 100 & 226,110 & 719 & 946 & 3.01 & 1762 & 5.60 \\
\hline
\end{tabular}

Figure 16. Emissions of $\mathrm{CO}_{2}$ versus engine power for the Raccoon.

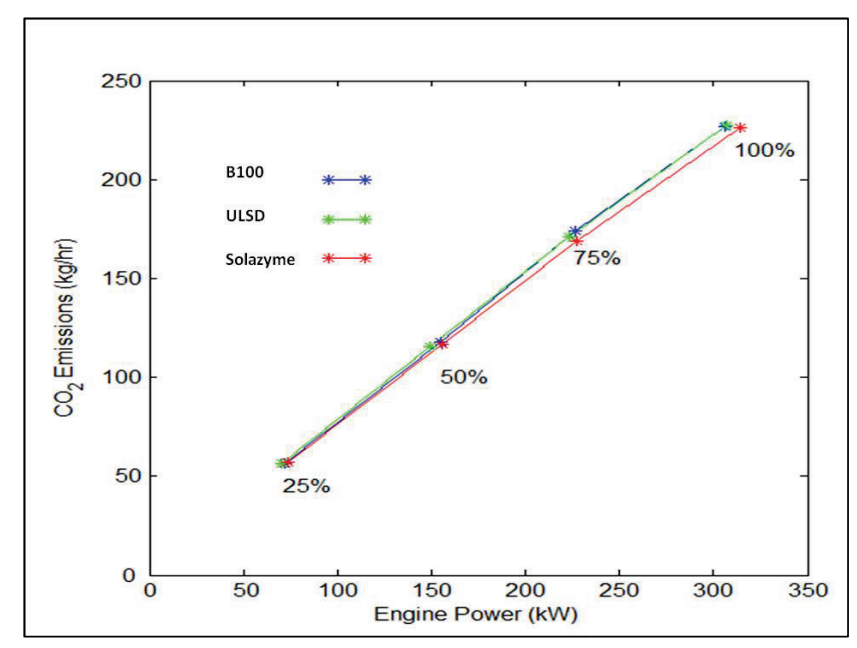


Figure 17. Emissions of $\mathrm{CO}_{2}$ for $\mathrm{B} 100$ (blue), ULSD (green), and Solazyme (red) fuels for the Raccoon.

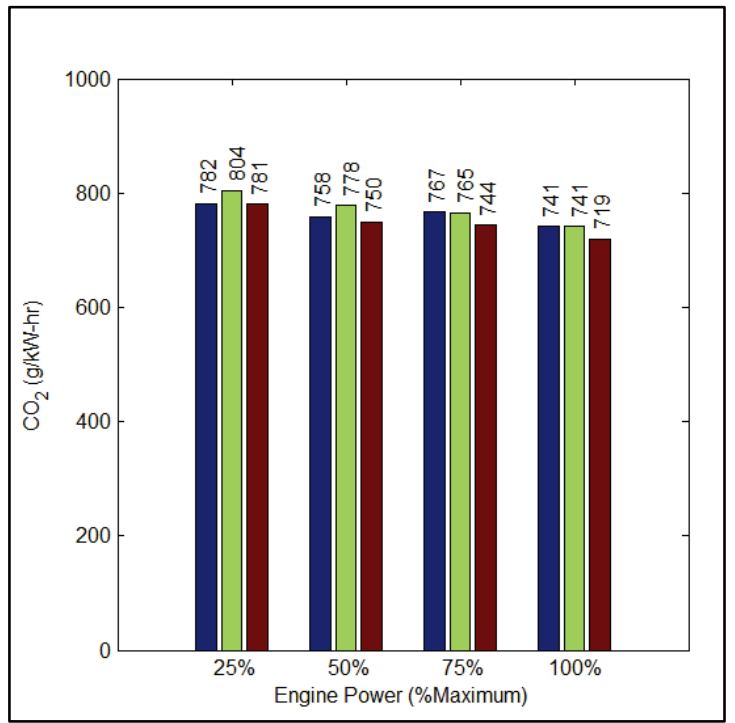

Figure 18. Emissions of $\mathrm{CO}$ versus engine power for the Raccoon.

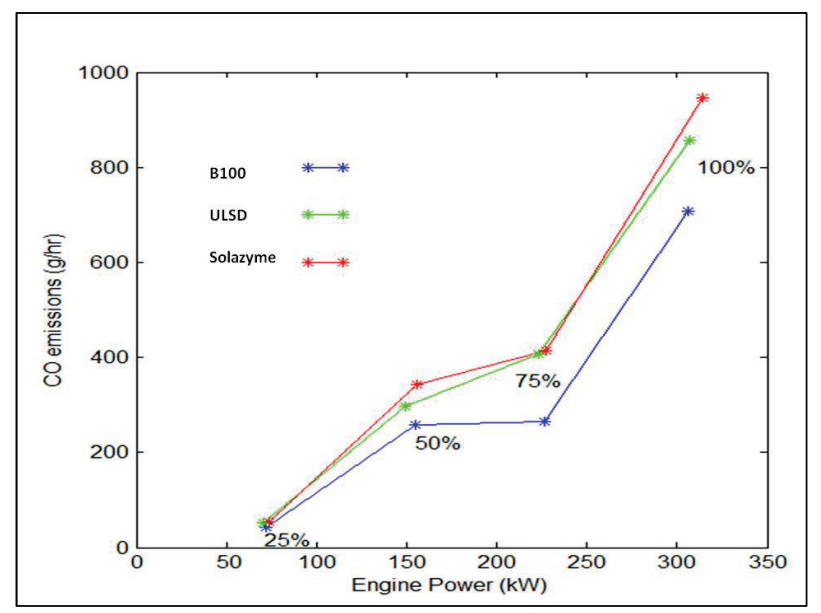


Figure 19. Emissions of $\mathrm{CO}$ for B100 (blue), ULSD (green), and Solazyme (red) fuels for the Raccoon.

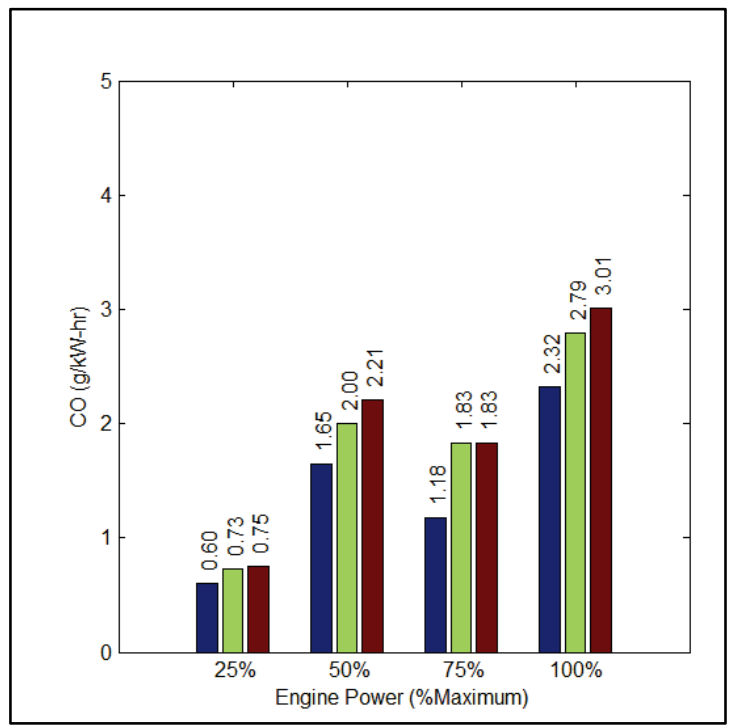

Figure 20. Emissions of $\mathrm{NO}_{\mathrm{x}}$ versus engine power for the Raccoon.

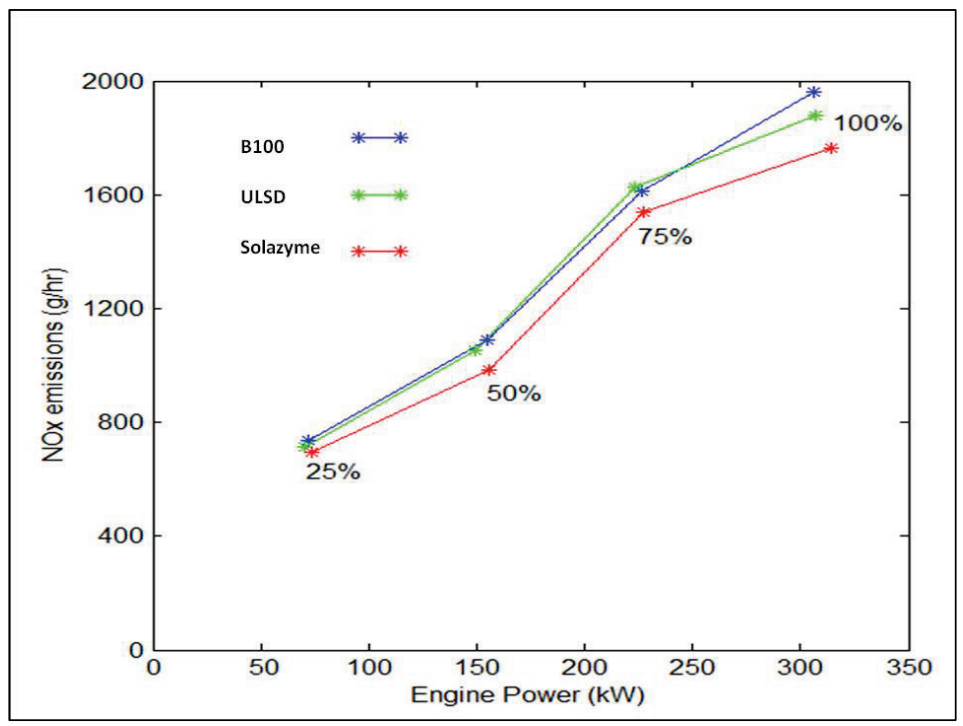


Figure 21. Emissions of $\mathrm{NO}_{x}$ for $\mathrm{B} 100$ (blue), ULSD (green), and Solazyme (red) fuels for the Raccoon.

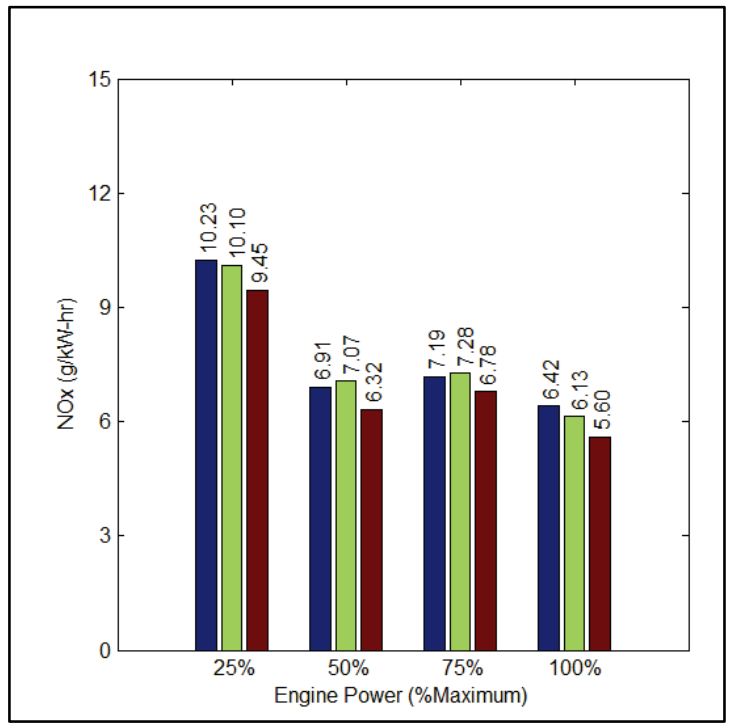

Table 9. Emissions of $\mathrm{PM}_{2.5}(\mathrm{~g} / \mathrm{kWhr})$ for the Raccoon.

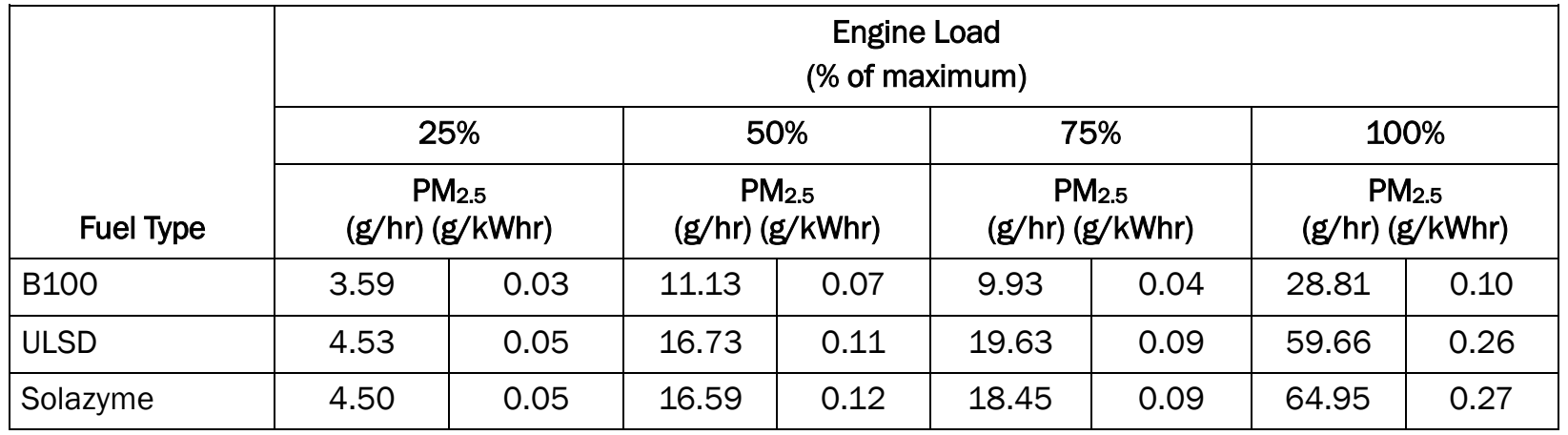

Figure 22. Emissions of $\mathrm{PM}_{2.5}$ versus engine power for the Raccoon.

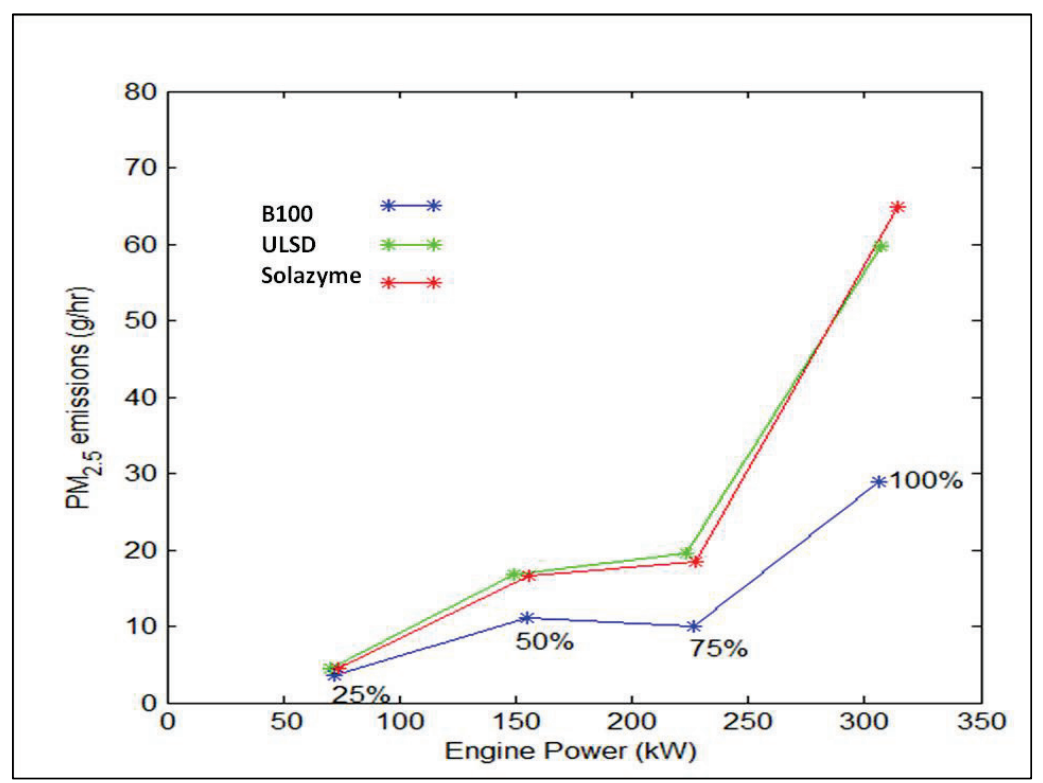


Figure 23. Emissions of $\mathrm{PM}_{2.5}$ for $\mathrm{B} 100$ (blue), ULSD (green), and Solazyme (red) fuels for the Raccoon.

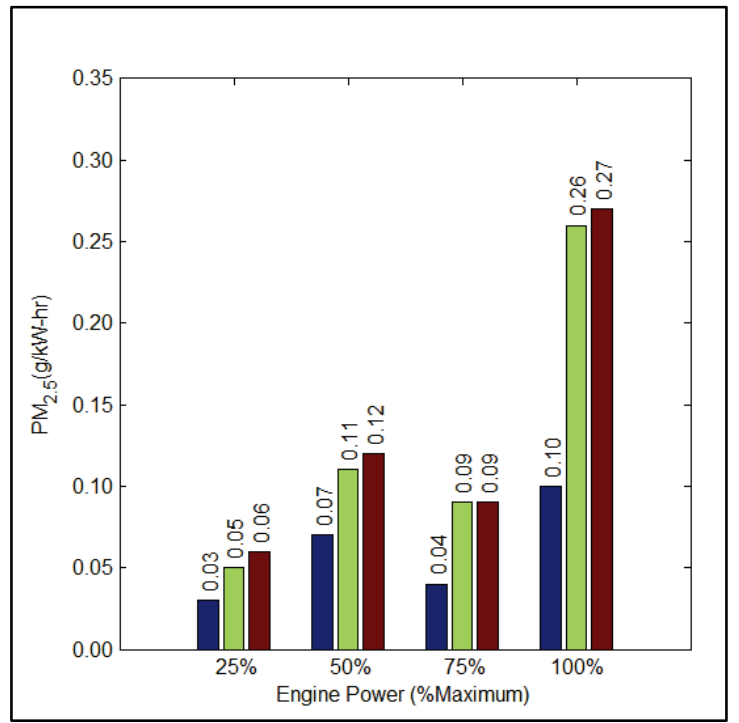

During the testing on the $B D-5$, problems developed with the strain gauges, and the measurements of strain at various operating points are unreliable. However, the RPM measurements, emission concentrations, and flow rates are believed to be accurate. Therefore, brake-specific emissions and fuel consumption at the load points are not reported for the $B D-5$. The unreferenced fuel consumption for the $B D-5$ is listed in Table 10 and plotted in Figure 24. The emissions of $\mathrm{CO}_{2}, \mathrm{CO}, \mathrm{NO}_{\mathrm{x}}$ and $\mathrm{PM}_{2.5}$ are listed in Table 11 and plotted in Figures 25 through 28.

Table 10. Fuel consumption for the BD-5.

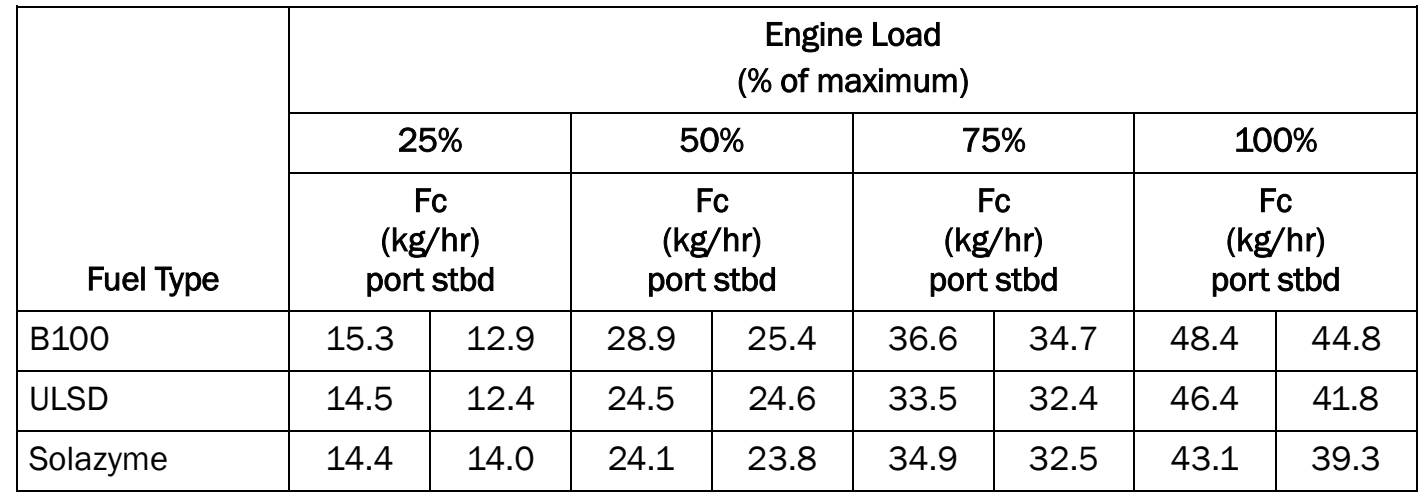


Figure 24. Fuel consumption versus engine power for the port engine (right) and the starboard engine (left) for the $B D-5$.

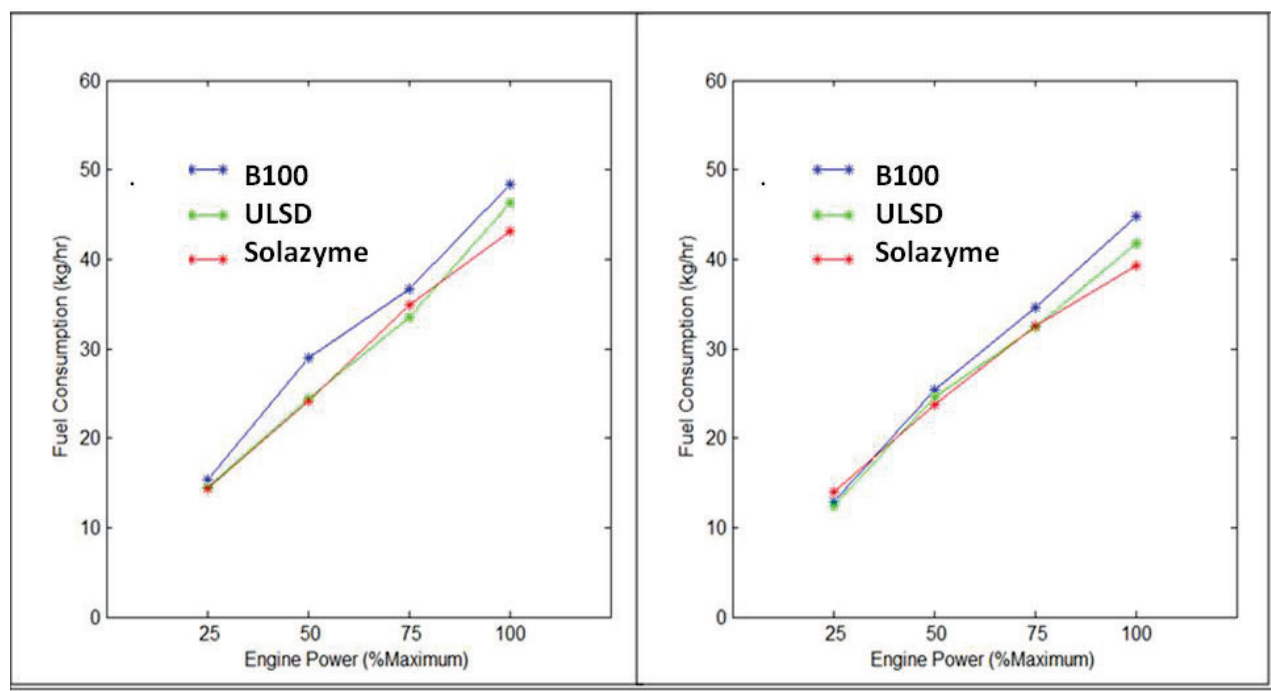

Table 11. Emissions of $\mathrm{CO}_{2}, \mathrm{CO}$, and $\mathrm{NO}_{x}$ and $\mathrm{PM}_{2.5}$ for the $B D-5$.

\begin{tabular}{|c|c|c|c|c|}
\hline $\begin{array}{c}\text { Engine Load } \\
\text { (\% of maximum) }\end{array}$ & $\begin{array}{c}\mathrm{CO}_{2} \text { Emissions } \\
\mathrm{g} / \mathrm{hr}\end{array}$ & $\begin{array}{c}\text { CO Emissions } \\
\mathrm{g} / \mathrm{hr}\end{array}$ & $\begin{array}{c}\mathrm{NO}_{\mathrm{x}} \text { Emissions } \\
\mathrm{g} / \mathrm{hr}\end{array}$ & $\begin{array}{c}\mathrm{PM}_{2.5} \text { Emissions } \\
\mathrm{g} / \mathrm{hr}\end{array}$ \\
\hline \multicolumn{5}{|c|}{ B100 } \\
\hline 25 & 32,946 & 57 & 433 & 12.42 \\
\hline 50 & 70,896 & 74 & 899 & 8.50 \\
\hline 75 & 97,042 & 63 & 1206 & 6.59 \\
\hline 100 & 131,127 & 111 & 1482 & 9.44 \\
\hline \multicolumn{5}{|c|}{ ULSD } \\
\hline 25 & 34,160 & 54 & 379 & 9.79 \\
\hline 50 & 63,327 & 93 & 667 & 19.58 \\
\hline 75 & 95,393 & 79 & 984 & 15.41 \\
\hline 100 & 133,592 & 141 & 1433 & 18.51 \\
\hline \multicolumn{5}{|c|}{ Solazyme } \\
\hline 25 & 31,969 & 49 & 317 & 11.22 \\
\hline 50 & 62,068 & 84 & 604 & 16.27 \\
\hline 75 & 97,745 & 101 & 873 & 14.22 \\
\hline 100 & 135,476 & 190 & 1211 & 17.98 \\
\hline
\end{tabular}


Figure 25. Emissions of $\mathrm{CO}_{2}$ versus engine power for the $B D-5$.

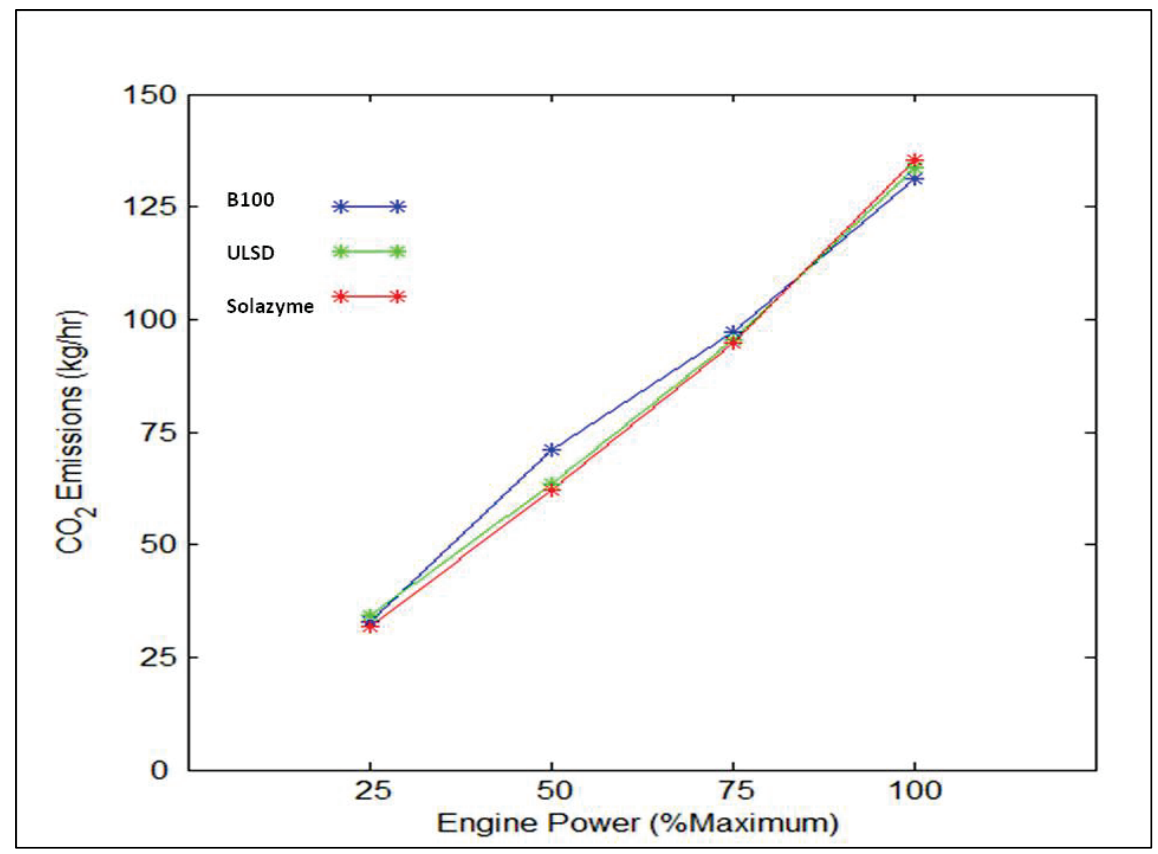

Figure 26. Emissions of $C O$ versus engine power for the $B D-5$.

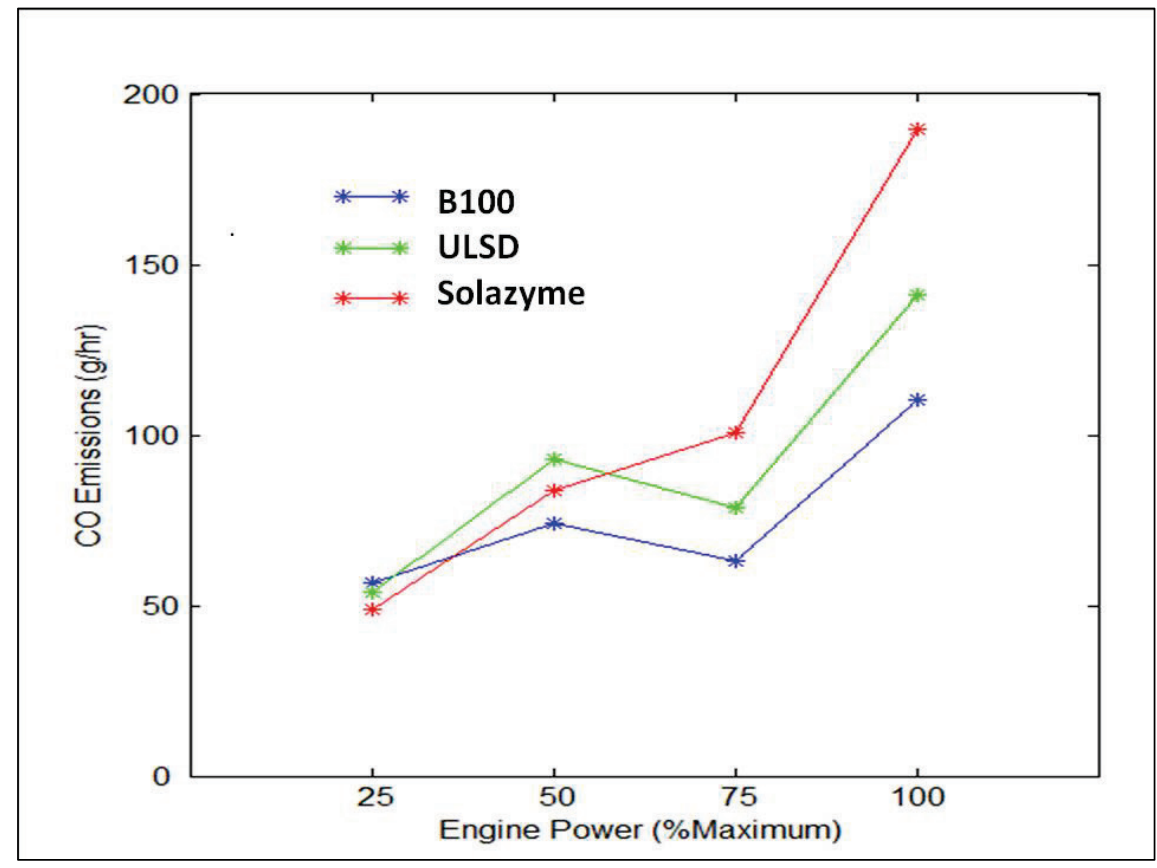


Figure 27. Emissions of $\mathrm{NO}_{x}$ versus engine power for the $B D-5$.

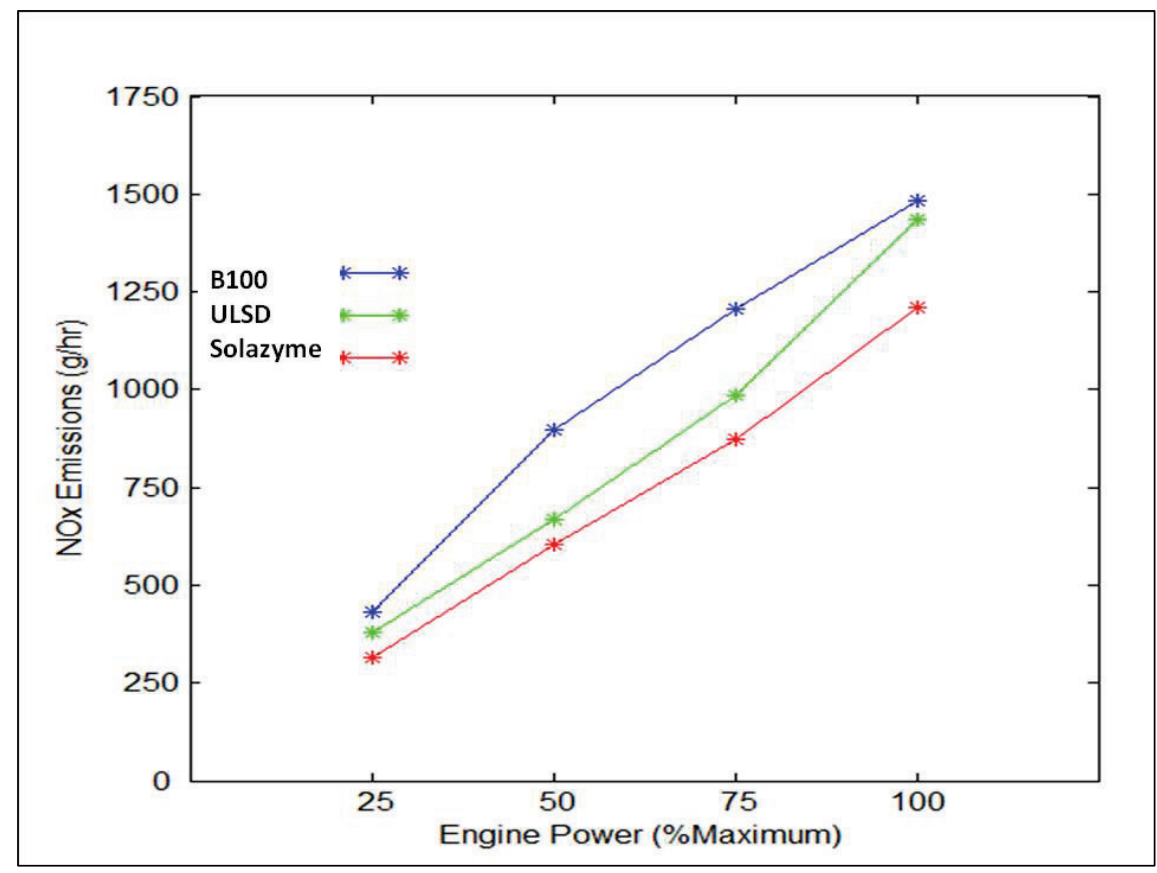

Figure 28. Emissions of $\mathrm{PM}_{2.5}$ versus engine power for the $B D-5$.

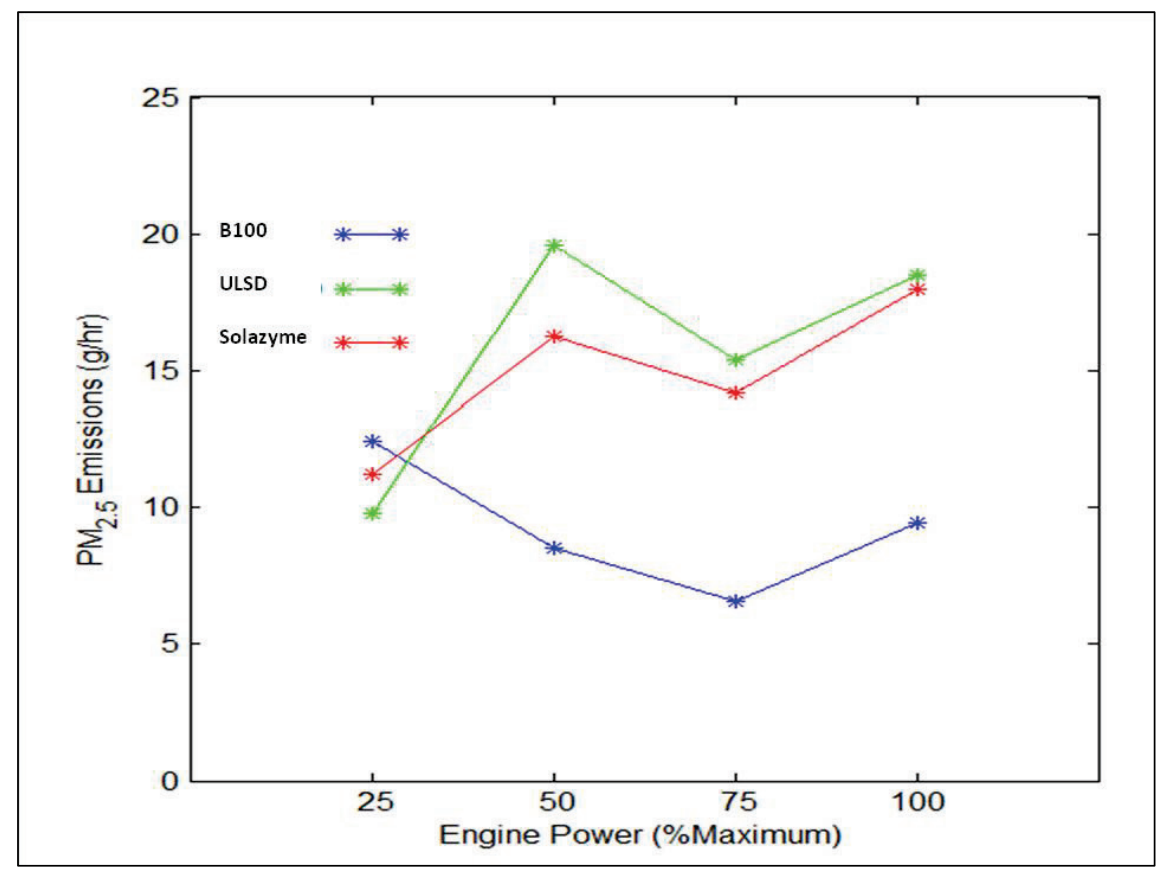

For the Raccoon, the B100 fuel consumption was higher than the ULSD fuel consumption (Table 7 and Figures 14 and 15) by $5.5 \mathrm{~kg} / \mathrm{hr}$ (100\% load), 5.4 $\mathrm{kg} / \mathrm{hr}$ (75\% load), $3.6 \mathrm{~kg} / \mathrm{hr}$ (50\% load), and $1.3 \mathrm{~kg} / \mathrm{hr}$ (25\% load).

Expressed as a percentage of the ULSD fuel consumption, the B100 fuel consumption was $7.7 \%, 10.1 \%$, 9.9\%, and 7.3\% higher. In terms of volume, 
because the B10o is denser than the ULSD, the differences in fuel consumption expressed as a percentage of the ULSD fuel consumption were $1.1 \%, 3.3 \%, 3.5 \%$, and $0.5 \%$ higher. For the $B D-5$, the B10o fuel consumption was higher than the ULSD fuel consumption (Table 10 and Figure 15) by $2.0 \mathrm{~kg} / \mathrm{hr}$ (port) and $3.0 \mathrm{~kg} / \mathrm{hr}$ (stbd) (100\%), $3.1 \mathrm{~kg} / \mathrm{hr}$ (port) and 2.3 $\mathrm{kg} / \mathrm{hr}$ (stbd) (75\%), $4.4 \mathrm{~kg} / \mathrm{hr}$ (port) and $0.8 \mathrm{~kg} / \mathrm{hr}$ (stbd) (50\%), and 0.8 $\mathrm{kg} / \mathrm{hr}$ (port) and $0.5 \mathrm{~kg} / \mathrm{hr}$ (stbd) (25\%) kg/hr. Expressed as a percentage of ULSD, B10o fuel consumption was $4.3 \%$ and $7.2 \%$, $0.9 \%$ and $7.1 \%, 18.0 \%$ and $3.3 \%$, and $5.5 \%$ and $4.0 \%$ higher. In terms of volume, the differences in fuel consumption expressed as a percentage of ULSD fuel consumption were $-2.0 \%$ and $0.7 \%, 2.6 \%$ and $0.5 \%, 10.9 \%$ and $-3.2 \%$, and $-0.4 \%$ and $2.3 \%$ (positives indicate higher B10o fuel consumption and negatives indicate lower B100 fuel consumption than ULSD). With the exception of the volume difference for the $B D-5$ at $50 \%$ load, which stands out as being anomalous, these results don't reflect the known approximately $10 \%$ lower energy content by volume for B100 in comparison to ULSD.

In terms of weight, the Solazyme fuel consumption for the Raccoon was higher than the ULSD fuel consumption (Table 7 and Figures 14 and 15) by 0.5 (100\% load), 0.1 (75\% load), 0.7 (50\% load), and 0.4 ( $25 \%$ load) kg/hr. Expressed as a percentage of the ULSD fuel consumption, the Solazyme fuel consumption was $0.7 \%, 0.1 \%, 0.7 \%$, and $0.4 \%$ higher. In terms of volume, the Solazyme fuel consumption was higher by $4.6 \%, 3.8 \%, 5.6 \%$, and $6.0 \%$. For the $B D-5$ (Table 9 and Figure 22), the differences were -3.3 (port) and 2.5 (stbd) (100\%), 1.4 (port) and 0.1 (stbd) (75\%), -0.4 (port) and -0.8 (stbd) (50\%), and -0.1 (port) and 1.6 (stbd) (25\%) kg/hr. Expressed as a percentage of the ULSD fuel consumption the differences were $-7.1 \%$ and $5.9 \%, 4.2 \%$ and $0.3 \%,-1.6 \%$ and $3.3 \%$, and $-0.7 \%$ and $12.9 \%$. In terms of volume, the differences are -3.7 and $-2.4,7.9$ and $3.8,1.9$ and $0.3,3.1$ and 17.1 (positives indicate higher Solazyme fuel consumption and negatives indicate lower Solazyme fuel consumption than ULSD).

For the Raccoon, the $\mathrm{CO}_{2}$ emissions as a function of fuel type (Table 8 and Figures 16 and 17) were relatively consistent (differences less than 5\%) and referenced to engine power (Figure 17), they decrease with engine load. The CO emissions (Table 8 and Figures 18 and 19) for B10o are significantly less than they are for ULSD or Solazyme, with a large reduction occurring between $50 \%$ and $75 \%$ loads. Solazyme had approximately the same CO emissions as ULSD for the $25 \%$ and $75 \%$ loads and higher CO emissions at the 50\% and 100\% loads. For $\mathrm{NO}_{\mathrm{x}}$ emissions (Table 8 and Figures 20 and 
21), Solazyme, with its lower density and higher Cetane number, had lower emissions than ULSD or B100 at all loads. B10o and ULSD had about the same $\mathrm{NO}_{\mathrm{x}}$ emissions at all loads except the $100 \%$ load where B10o had higher $\mathrm{NO}_{\mathrm{x}}$ emissions. The $\mathrm{PM}_{2.5}$ emissions (Table 9 and Figures 22 and 23) were significantly lower for B100 than for ULSD or Solazyme at all loads. The large reduction in $\mathrm{PM}_{2.5}$ can be attributed to a much lower aromatic content of B100.

For the $B D-5$, the $\mathrm{CO}_{2}$ emissions as a function of fuel type (Table 11 and Figure 25) are within $5 \%$ of those for B100, with the exception of the difference at 50\% load. The 50\%-load result, which was the case for the fuel consumption, stands out as being anomalous, shows approximately $11 \%$ less $\mathrm{CO}_{2}$ emissions for ULSD in comparison to $\mathrm{B} 100$, and approximately $12 \%$ less for Solazyme. The significantly less CO emissions (Table 11 and Figure 26) for B100 in comparison to ULSD and Netste for the 50\%, 75\%, and $100 \%$ loads for the $B D-5$ agree with the results for the Raccoon, but unlike the Raccoon, the $\mathrm{B} 100 \mathrm{CO}$ emissions for $B D-5$ at the $25 \%$ load are slightly greater than they are for ULSD and Solazyme. Solazyme had higher CO emissions than ULSD at the $75 \%$ and $100 \%$ loads and lower CO emissions for the $25 \%$ and $50 \%$ loads. Like the result for the Raccoon, Solazyme had lower $\mathrm{NO}_{\mathrm{x}}$ emissions (Table 11 and Figure 27) than $\mathrm{B} 100$ and ULSD at all loads. The $\mathrm{NO}_{\mathrm{x}}$ emissions were higher for $\mathrm{B} 100$ than they were for ULSD at all loads. The $\mathrm{PM}_{2.5}$ emissions (Table 11 and Figure 28) for the $B D-5$ were much lower for B10o than they were for ULSD or Solazyme at the $50 \%, 75 \%$, and $100 \%$ loads and higher at the $25 \%$ load.

With the exception of the anomalous results for the $B D-5$ at the $50 \%$ load, these results indicate that $\mathrm{CO}_{2}$ emissions are approximately the same, regardless of the type of fuel used, and overall, $\mathrm{CO}$ and $\mathrm{PM}_{2.5}$ emissions are lower when using B100. However, how much lower $\mathrm{CO}$ and $\mathrm{PM}_{2.5}$ emissions would be when using B100 as compared to ULSD or Solazyme, whether overall $\mathrm{NO}_{\mathrm{x}}$ emissions would be lower or higher for B10o than for ULSD, and how much lower $\mathrm{NO}_{\mathrm{x}}$ emissions would be for Solazyme in comparison to B100 or ULSD, all depend on the percentage of the time the vessels normally operate at the various loads.

Certification test cycles for marine vessels as defined in ISO 8178 (ISO 1996) follow the E3 test cycle that specifies operations at 100\% load $20 \%$ of the time, at $75 \%$ load $50 \%$ of the time and at $50 \%$ and $25 \%$ load $15 \%$ of the time each. Overall single emissions factors for each emission (i.e., $\mathrm{CO}_{2}$, 
$\mathrm{CO}, \mathrm{NO}_{\mathrm{x}}$, and $\mathrm{PM}_{2.5}$ ) are determined by weighting the modal data according to the specified load operations and summing them. The equation used for the overall emissions factors is the sum of the weighted emissions divided by the sum of the weighted engine powers at the $25 \%$, $50 \%, 75 \%$, and $100 \%$ loads. The weighting factors are $0.15,0.15,0.50$, and 0.20 , representing the specified operations times of the engine at those loads. Table 12 lists the emissions factors for the Raccoon. They are not shown for the BD-5, as a result of the unreliable power measurements on that vessel.

Table 12. Weighted emissions factors for the Raccoon ( $\mathrm{g} / \mathrm{kWhr}$ ).

\begin{tabular}{|c|c|c|c|}
\hline Emission & B100 & ULSD & Solazyme \\
\hline $\mathrm{CO}_{2}$ & 760.4 & 761.2 & 740.1 \\
\hline $\mathrm{CO}$ & 1.6 & 2.1 & 2.2 \\
\hline $\mathrm{NO}_{x}$ & 7.1 & 7.1 & 6.5 \\
\hline $\mathrm{PM}_{2.5}$ & 0.06 & 0.14 & 0.14 \\
\hline
\end{tabular}

EPA emissions standards are based on the emissions factors listed in Table 12. The Tier 2 emissions standards do not apply to $\mathrm{CO}_{2}$ and are 5.0 g/kWhr for CO, 7.2 g/kWhr for $\mathrm{NO}_{\mathrm{x}}$, and $0.11 \mathrm{~g} / \mathrm{kWhr}$ for $\mathrm{PM}_{2.5}$. The B100 is lower than the Tier 2 standards for all three regulated emissions. ULSD and Solazyme are lower than the Tier 2 standards for $\mathrm{CO}$ and $\mathrm{NO}_{\mathrm{x}}$ but are higher than the Tier 2 standard for $\mathrm{PM}_{2.5}$.

\section{Expanded operational experience results}

Operational testing of biodiesel fuel on all of the USACE vessels was evaluated by having the vessel operators fill out a questionnaire on their experiences with the fuels and report type and volume of biodiesel used. Four of the vessels used B10o (for varying lengths of time), and the others used fuels ranging from $\mathrm{B}_{5}$ to $\mathrm{B} 2 \mathrm{O}$. During the entire duration of the study (Feb 2011-April 2014), the approximate total volume of biodiesel consumed was 3.1 million gallons. Relative proportions for the different blends were $\mathrm{B}_{5}-1.34$ million gallons, B10 - 178,000 gallons, B15 653,000 gallons, $\mathrm{B} 20-848$,000 gallons, and $\mathrm{B} 100-43,000$ gallons. The majority of the $\mathrm{B}_{5}$ consumed was used by the dredge Yaquina, primarily for the purpose of adding lubricity to their ULSD fuel. With the exception of the Pathfinder using B10o initially, The MVS vessels started out using B5 and, as experience and confidence was gained, increased their biodiesel fraction in $5 \%$ increments till a maximum blend of B2O was reached (i.e., 
$5 \%, 10 \%, 15 \%, 20 \%)$. During the colder months the MVS primarily used B15 to mitigate cold flow issues. The $B D-5$ and $B D-6$ used B10o exclusively, and after having replaced the crossover fuel hoses degraded by B10o in the initial study on $B D-5$, no other negative issues were reported. The Raccoon, after being emissions tested with ULSD, B100, and Solazyme fuel oil, primarily used B2O over the duration of the expanded study.

In general, the crews of the vessels were favorably impressed with the reduction in soot and overall improved cleanliness that came with using biodiesel. The maintenance personnel also liked the cleaner appearance of the insides of the engines when using biodiesel, and one mentioned a potential for reduced maintenance that could result from using B10o. For example, one Chief remarked "have seen an improvement in our F/O centrifuge in how long it can go before overhauls." Several crew members also remarked on their increased sense of well being from an environmental and personal health perspective by knowing that biodiesel use reduces certain emissions and carcinogens. There were no maintenance issues associated with using biodiesel; however, all the vessels took the precaution of increasing the frequency of replacing fuel filters when they switched from ULSD to biodiesel. A subsequent gradual reduction in fuel filter change frequency was reported for several vessels, and it is assumed that the biodiesel use cleaned the varnish accumulated by prior regular diesel fuel use. None of the operators had any issues related to engine power or efficiency, and there were no negative effects on routine vessel operations. Several crews used the Flowscan fuel-flow system that, by comparing values to fuel tank soundings, can track performance of propulsion, generator, and pump engines for optimizing their respective operations, maintenance, and troubleshooting aspects. The cost of using biodiesel was reported to be comparable to that of using ULSD. NAB reported that by increasing the volume of B10o that they ordered (by adding BD-6 fuel requirements with BD-5), they experienced a reduction in price per gallon.

To make realistic comparisons in the differences in emissions between the different fuels, knowledge of the normal operating conditions for the vessels are needed. USACE vessels have a wide range of operating conditions. For example, one of the vessels used in the operational tests was the MVS dustpan dredge Potter. They estimate that they operate the Potter at $25 \%$ load $20 \%$ of the time, $50 \%$ load $75 \%$ of the time, and $75 \%$ load $5 \%$ of the time. They estimate that they never operate the vessel at $100 \%$ load. Conversely, another vessel used in the operational tests was the MVS push- 
tug Grand Tower. They estimate that they operate the Grand Tower at 25\% and $50 \%$ loads $15 \%$ of the time each, $75 \%$ load $65 \%$ of the time, and $100 \%$ load $5 \%$ of the time. Drift collection vessels like the Raccoon and $B D-5$ typically operate at $25 \%$ load $10 \%$ of the time, $50 \%$ load $20 \%$ of the time, $75 \%$ load $50 \%$ of the time, and $100 \%$ load $20 \%$ of the time. 


\section{Conclusions}

Operational testing of biodiesel fuel manufactured from soybeans was conducted on 14 USACE vessels to evaluate the feasibility of using alternative fuels in USACE floating plant operations to reduce environmentally sensitive emissions, increase use of renewable energy, and reduce the use of fossil fuels. Types of vessels used in the study included a dustpan dredge, a hopper dredge, four towboats, three debrisremoval vessels, three crane barges, a tug, and a crew boat. There were differing levels of monitoring applied on different vessels ranging from the most basic level of evaluation that consisted of using biodiesel during normal operations and surveying the crew regarding their opinion on its operational suitability (e.g., delivered power, engine condition), to the highest level of evaluation that consisted of installing instrumentation onboard select vessels to monitor fuel use, engine power, and levels of emissions at preselected levels of engine loading. Five of the vessels used B10o (for varying lengths of time), and the others used fuels ranging from B5 to B20. During the duration of the study (Feb 2011 through April 2014), the approximate total volume of biodiesel consumed was 3.1 million gallons, averaging approximately $9 \%$ of the total diesel fuel consumption for USACE floating plant. Relative proportions for the different blends were $\mathrm{B}_{5}-1.34$ million gallons, B10 - 178,000 gallons, B15 - 653,000 gallons, B2O - 848,000 gallons, and B100 - 43,000 gallons.

In general, the crews of the vessel were favorably impressed with the reduction in soot and overall improved cleanliness that came with using biodiesel. The maintenance personnel also liked the cleaner appearance of the insides of the engines when using biodiesel, and one mentioned a potential for reduced maintenance that could result from using B10o. There were no significant maintenance issues associated with using biodiesel; however, all the vessels took the precaution of increasing the frequency of replacing fuel filters when they switched from ULSD to biodiesel. None of the operators had any issues related to engine power or efficiency, and with the exception of one load of biodiesel that did not meet ASTM D6751 standards, there were no negative effects on routine vessel operations. No noticeable performance impacts were observed going back and forth from diesel fuel to biodiesel use. The cost of using biodiesel was reported to be comparable to that of using ULSD, and similar to NOAA 
LMFS experience, one District reported a reduction in cost per gallon of biodiesel when the volume of ordered fuel was increased. Several crews use the fuel-flow measurement system that was installed during the study to subsequently track performance of propulsion, generator, and pump engines for optimizing their respective operations, maintenance, and troubleshooting activities.

Emissions testing for $\mathrm{CO}_{2}, \mathrm{CO}, \mathrm{NO}_{\mathrm{x}}$, and $\mathrm{PM}_{2.5}$ was conducted on two USACE debris-removal vessels at 25\%, 50\%, 75\%, and $100 \%$ engine loads with three different fuels, B100, ULSD, and Solazyme. The emissions testing showed $\mathrm{CO}_{2}$ emissions to be approximately the same for all three fuels at the target loads. The $\mathrm{CO}$ emissions for $\mathrm{B} 100$ were significantly less than they were for ULSD or Solazyme. The $\mathrm{NO}_{\mathrm{x}}$ emissions were generally slightly higher for B100 in comparison to ULSD and significantly higher than for Solazyme. The $\mathrm{PM}_{2.5}$ emissions were significantly less for B100 in comparison to ULSD and Solazyme, except at the $25 \%$ load on one of the vessels where they were slightly higher. Solazyme, with its higher cetane number, had the lowest $\mathrm{NO}_{\mathrm{x}}$ emissions.

Fuel consumption was measured during the emissions testing. It was expected that the approximately 10\% lower energy content of a gallon of B100 in comparison to a gallon of ULSD would mean a 10\% increase in fuel consumption of $\mathrm{B} 100$ at the load points. However, the measurements didn't show this result. For one of the vessels, the B10o fuel consumption was measured to be approximately an average $2 \%$ higher than ULSD. For the other vessels, the average B100 consumption was approximately $1 \%$ lower after an anomalous measurement at 50\% load was excluded.

Emissions factors as defined in ISO 8178 (ISO 1996) were calculated from the emissions measurements. It was found that $\mathrm{B} 100$ was lower than the EPA Tier 2 standards for all three regulated emissions (i.e., $\mathrm{CO}, \mathrm{NO}_{\mathrm{x}}$, $\mathrm{PM}_{2.5}$ ). The ULSD and Solazyme were lower than the Tier 2 standards for $\mathrm{CO}$ and $\mathrm{NO}_{\mathrm{x}}$ but higher than the Tier 2 standard for $\mathrm{PM}_{2.5}$.

This study successfully demonstrated that the use of certified biodiesel fuel (including biodiesel manufactured from soybeans and from algal oils), by suitable USACE floating plants, is feasible to reduce select environmentally sensitive emissions, increase USACE use of renewable energy, and reduce the use of fossil fuels. All of the Districts that participated in the expanded study intend to continue their respective use of biodiesel fuel. 


\section{References}

Council on Environmental Quality. 2009. Federal leadership in environmental, energy and economic performance. Executive Order 13514. Washington, DC. https://www.whitehouse.gov/administration/eop/ceq/sustainability

International Organization for Standardization (ISO). 1996. Reciprocating internal combustion engines-Exhaust emission measurement. ISO 8178, 1st edition, 1996-08-15. Geneva, Switzerland.

U.S. Department of Energy (DOE). 2003. Just the basics. Washington, DC: Office of Energy Efficiency and Renewable Energy.

www1.eere.energy.energy.gov/vehiclesandfuels/pdfs/basics/jtb_diesel_engine.pdf

. 2014. Energy efficiency \& renewable energy. Washington, DC: U.S. Department of Energy. http://www.fueleconomy.gov/feg/biodiesel.shtml

Velmurugan, K., and S. Gowthamn. 2012. Effect of cetane improver additives on emissions. International Journal of Modern Engineering Research 2(5):33723375 . 


\section{Appendix A: Vessels in Expanded Study}

Table A1. Expanded operational testing and biodiesel evaluation study of floating plant equipment descriptions.

\begin{tabular}{|c|c|c|c|c|c|}
\hline Location & District & Vessel & Dredge Pump & Propulsion & Generator \\
\hline $\begin{array}{l}\text { Washington, DC } \\
\text { Debris Unit }\end{array}$ & NAB & $\begin{array}{l}\text { BD-6 (11 m) drift } \\
\text { collection vessel, } \\
\text { 1991, fuel cap, } \\
\text { 1,892 L } \\
\text { (500 gal) }\end{array}$ & & $\begin{array}{l}\text { (2) Caterpillar } \\
3208\end{array}$ & $\begin{array}{l}1 \text { Yanmar, YDG } \\
\text { 3700EV -Engine } \\
\text { Model \# } \\
\text { L100EE-DEGLE }\end{array}$ \\
\hline $\begin{array}{l}\text { St. Louis, MO } \\
\text { Base Yard }\end{array}$ & MVS & $\begin{array}{l}\text { Grandtower }(20 \mathrm{~m}) \\
\text { towboat, } 2000, \\
\text { fuel cap. } 35,200 \mathrm{~L} \\
(9,300 \text { gal })\end{array}$ & & $\begin{array}{l}2 \text { Caterpillar } \\
3406 \mathrm{E}\end{array}$ & $\begin{array}{l}\text { (2) John Deere } \\
\text { 4045TFM }\end{array}$ \\
\hline \begin{tabular}{|l} 
St. Louis, MO \\
Base Yard
\end{tabular} & MVS & \begin{tabular}{|l} 
Dustpan Dredge \\
Potter, (74 m) \\
1932, fuel cap. \\
113,550 L \\
$(30,000$ gal)
\end{tabular} & & $\begin{array}{l}\text { Electric motor } 2 \\
\text { Caterpillar 3406E }\end{array}$ & $\begin{array}{l}\text { 3 Caterpillar } \\
\text { 3516B(2) John } \\
\text { Deere } \\
\text { 4045TFM }\end{array}$ \\
\hline $\begin{array}{l}\text { Portland District } \\
\text { Moorings }\end{array}$ & NWP & $\begin{array}{l}\text { Hopper Dredge } \\
\text { Yaquina } \\
61 \mathrm{~m} \\
1981\end{array}$ & $\begin{array}{l}2 \text { Caterpillar D- } \\
379\end{array}$ & $\begin{array}{l}2 \text { Tier II MTU } \\
8 V 4000 \text { M60 }\end{array}$ & $\begin{array}{l}\text { Two Tier II MTU } \\
\text { 12V2000 P82 }\end{array}$ \\
\hline $\begin{array}{l}\text { St. Louis, MO } \\
\text { Base Yard }\end{array}$ & MVS & \begin{tabular}{|l|} 
Derrick No. 6 \\
Crane Barge $21(\mathrm{~m})$ \\
2006, \\
fuel cap. $5,830 \mathrm{~L}$ \\
$(1,450$ gal $)$
\end{tabular} & $\begin{array}{l}2 \text { Caterpillar D- } \\
379\end{array}$ & $\begin{array}{l}2 \text { Tier II MTU } \\
8 \text { 84000 M60 }\end{array}$ & $\begin{array}{l}\text { Main Generator } \\
\text { John Deer } \\
\text { 45T100-5000 } \\
\text { Auxiliary } \\
\text { Generator John } \\
\text { Deer 45D71- } \\
\text { 5000Two Tier II } \\
\text { MTU 12V2000 } \\
\text { P82 }\end{array}$ \\
\hline $\begin{array}{l}\text { St. Louis, MO } \\
\text { Base Yard }\end{array}$ & MVS & $\begin{array}{l}\text { Prairie du Rocher, } \\
\text { Towboat }(16 \mathrm{~m}) \\
2002, \text { fuel cap. } \\
4,920 \mathrm{~L} \\
(1,300 \text { gal })\end{array}$ & & (2) Cat 3406E & $\begin{array}{l}\text { (2) John Deere } \\
\text { 4045TFMMain } \\
\text { Generator John } \\
\text { Deer 45T100- } \\
5000 \\
\end{array}$ \\
\hline $\begin{array}{l}\text { St. Louis, MO } \\
\text { Base Yard }\end{array}$ & MVS & $\begin{array}{l}\text { Kimmswick, } \\
\text { Towboat }(16 \text { m) } \\
\text { 2006, fuel cap. } \\
4,920 \text { L } \\
\text { (1,300 gal) }\end{array}$ & & $\begin{array}{l}\text { (2)Cat C18(2) Cat } \\
3406 \mathrm{E}\end{array}$ & $\begin{array}{l}\text { (2) John Deere } \\
\text { T04045DFM(2) } \\
\text { John Deere } \\
\text { 4045TFM }\end{array}$ \\
\hline \begin{tabular}{|l} 
St. Louis, MO \\
Base Yard
\end{tabular} & MVS & $\begin{array}{l}\text { Barron, Crewboat, } \\
\text { (11 m) 1998, fuel } \\
\text { cap. 1,514 L } \\
\text { (400 gal) }\end{array}$ & & \begin{tabular}{|l|}
2 - Caterpillar \\
model 3116, in line \\
6, \\
turbocharged(2)Cat \\
C18
\end{tabular} & $\begin{array}{l}\text { Northern Lights } \\
\text { model BKW-PX- } \\
\text { 6-303(2) John } \\
\text { Deere } \\
\text { T04045DFM }\end{array}$ \\
\hline
\end{tabular}




\begin{tabular}{|l|l|l|l|l|l|}
\hline Location & District & Vessel & Dredge Pump & Propulsion & Generator \\
\hline $\begin{array}{l}\text { St. Louis, MO } \\
\text { Base Yard }\end{array}$ & MVS & $\begin{array}{l}\text { Fisher, Crane Barge } \\
\begin{array}{l}48(\mathrm{~m}) \text { 1999, fuel } \\
\text { cap. 11,355 L } \\
(3,000 \text { gal })\end{array}\end{array}$ & & $\begin{array}{l}\text { 2 - Caterpillar } \\
\text { model 3116, in line } \\
\text { 6, turbocharged }\end{array}$ & $\begin{array}{l}\text { Northern Lights } \\
\text { model BKW-PX- } \\
\text { 6-303 }\end{array}$ \\
\hline $\begin{array}{l}\text { St. Louis, MO } \\
\text { Base Yard }\end{array}$ & MVS & $\begin{array}{l}\text { Sewell, Crane } \\
\text { Barge 60 (m) } \\
\text { 1985, fuel cap. } \\
7,570 \text { L } \\
\text { (2,000 gal) }\end{array}$ & & & 2 - Detroit \\
& & & & \\
Diesel, 16V-71T \\
\end{tabular}

Figure A1. U.S. Army Engineer District Baltimore (NAB) drift collection vessel $B D-6$.

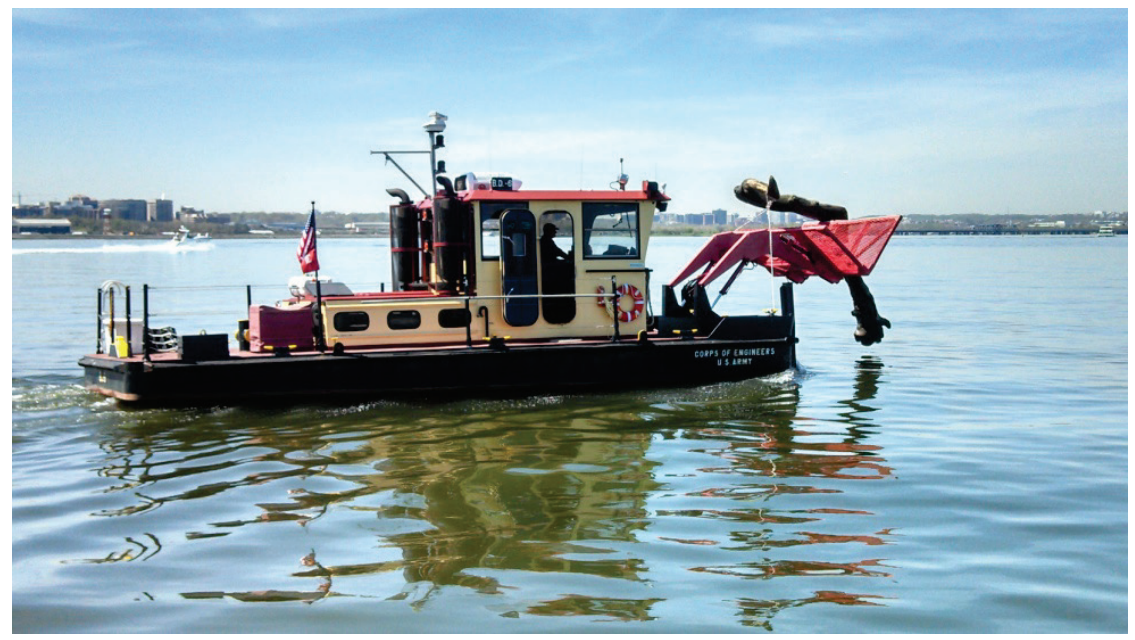

Figure A2. U.S. Army Engineer District St. Louis (MVS) dustpan dredge Potter.
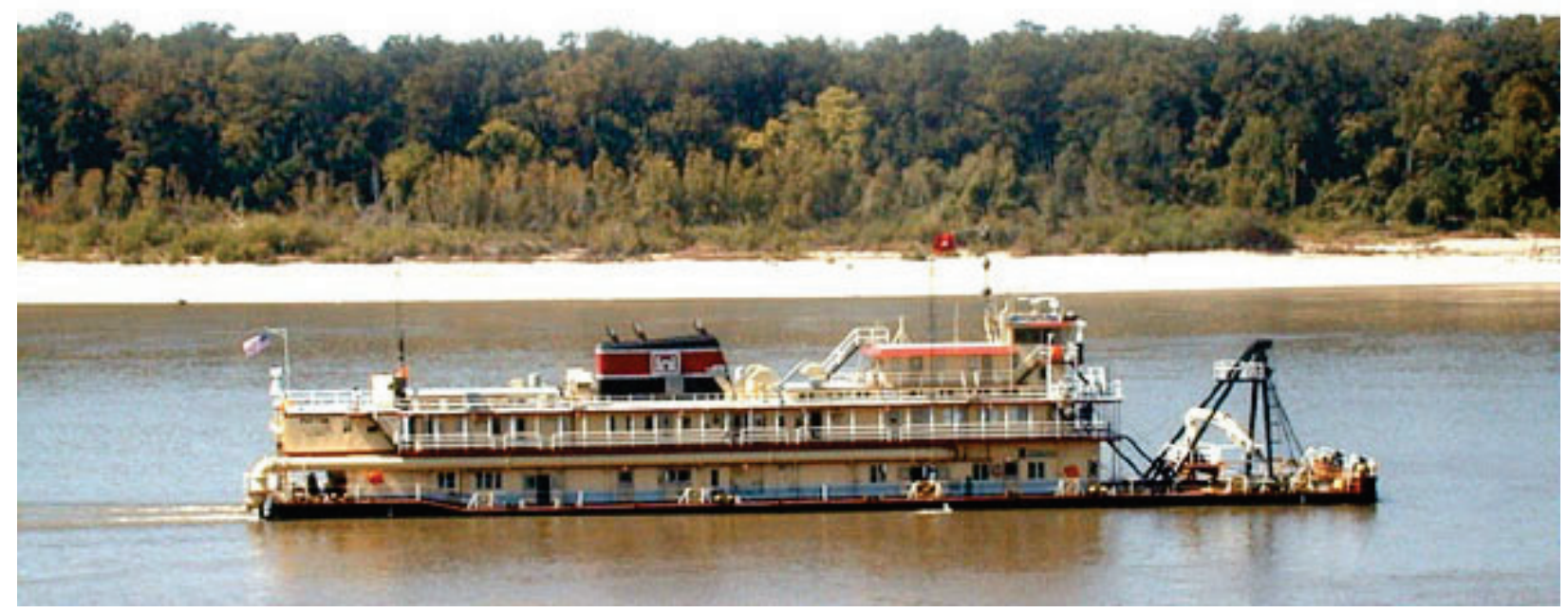
Figure A3. U.S. Army Engineer District Portland (NWP) hopper dredge Yaquina.

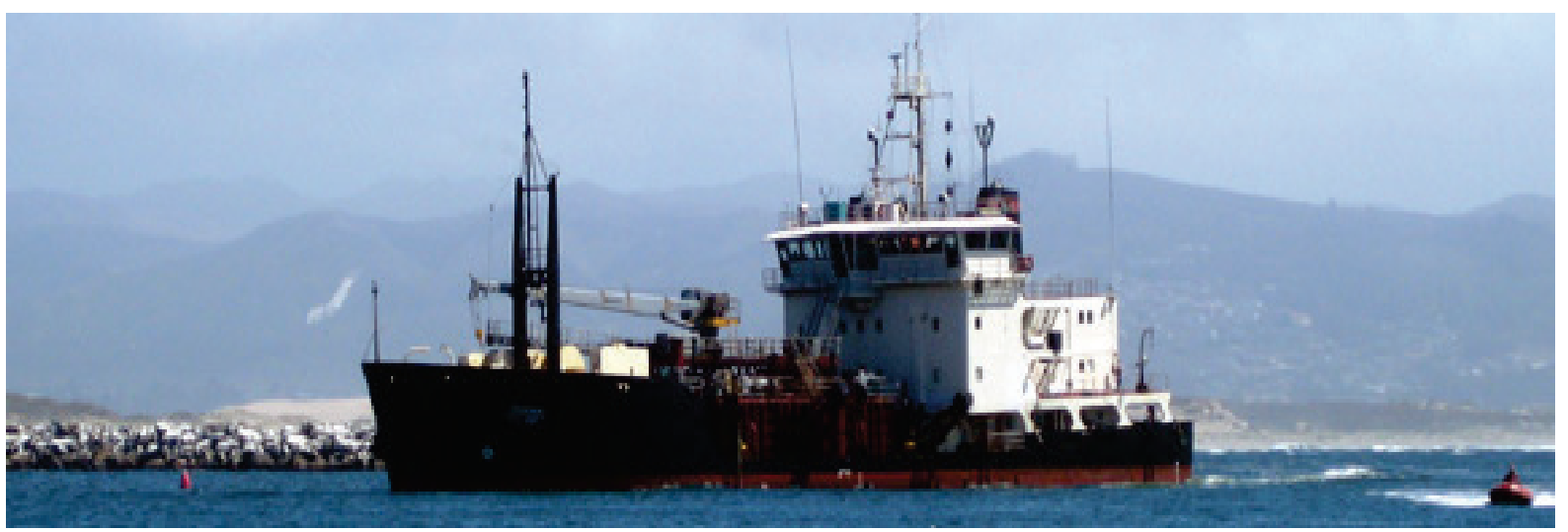

Figure A4. U.S. Army Engineer District St Louis (MVS) towboat GrandTower.

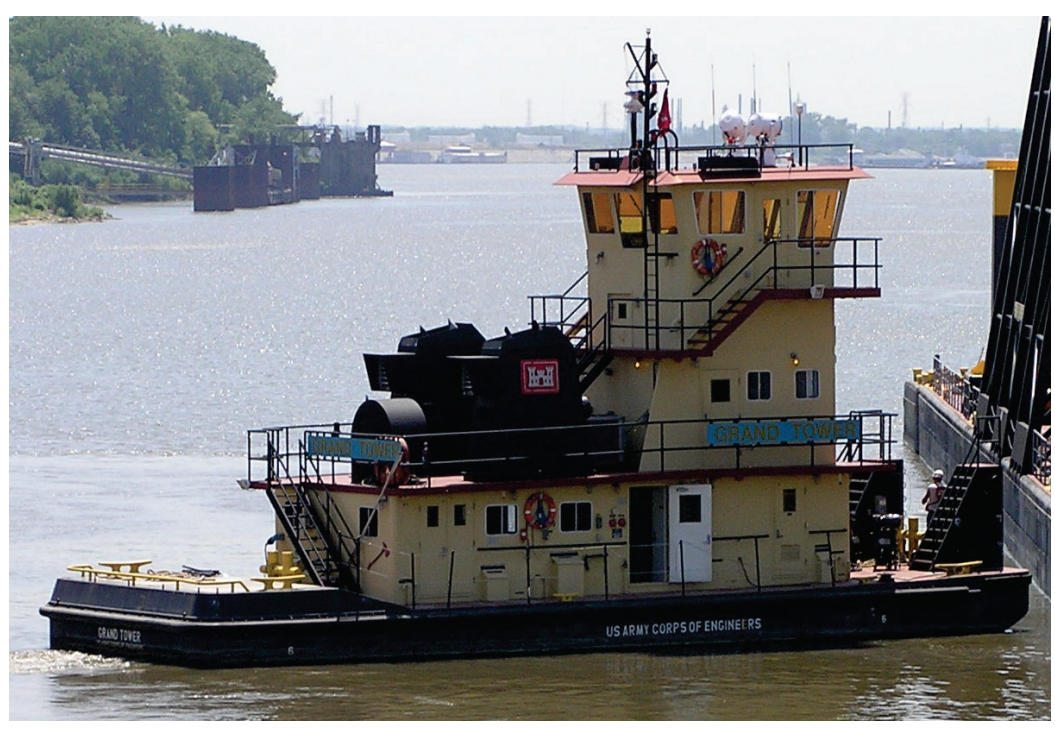

Figure A5. U.S. Army Engineer District St Louis (MVS) towboat Prairie du Rocher.

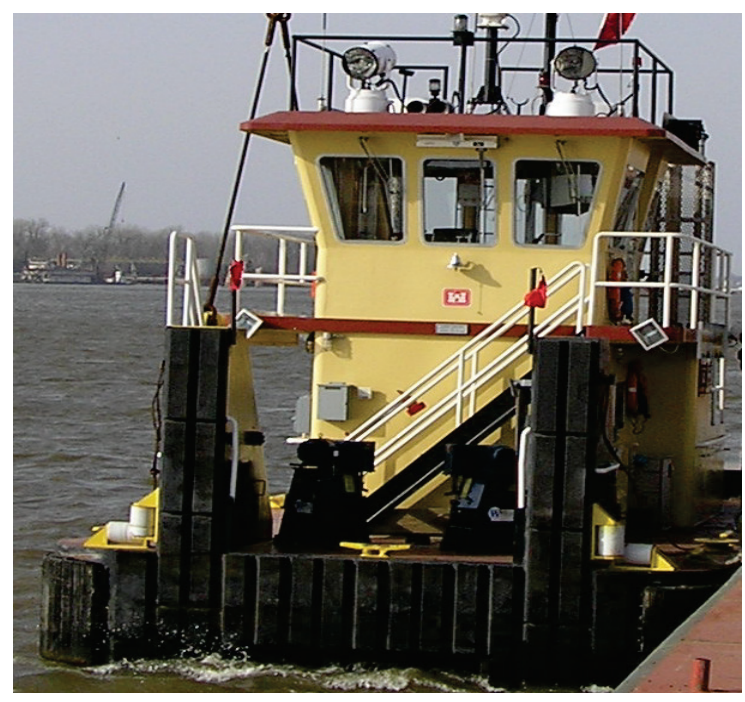


Figure A6. U.S. Army Engineer District St Louis (MVS) towboat Kimmswick.

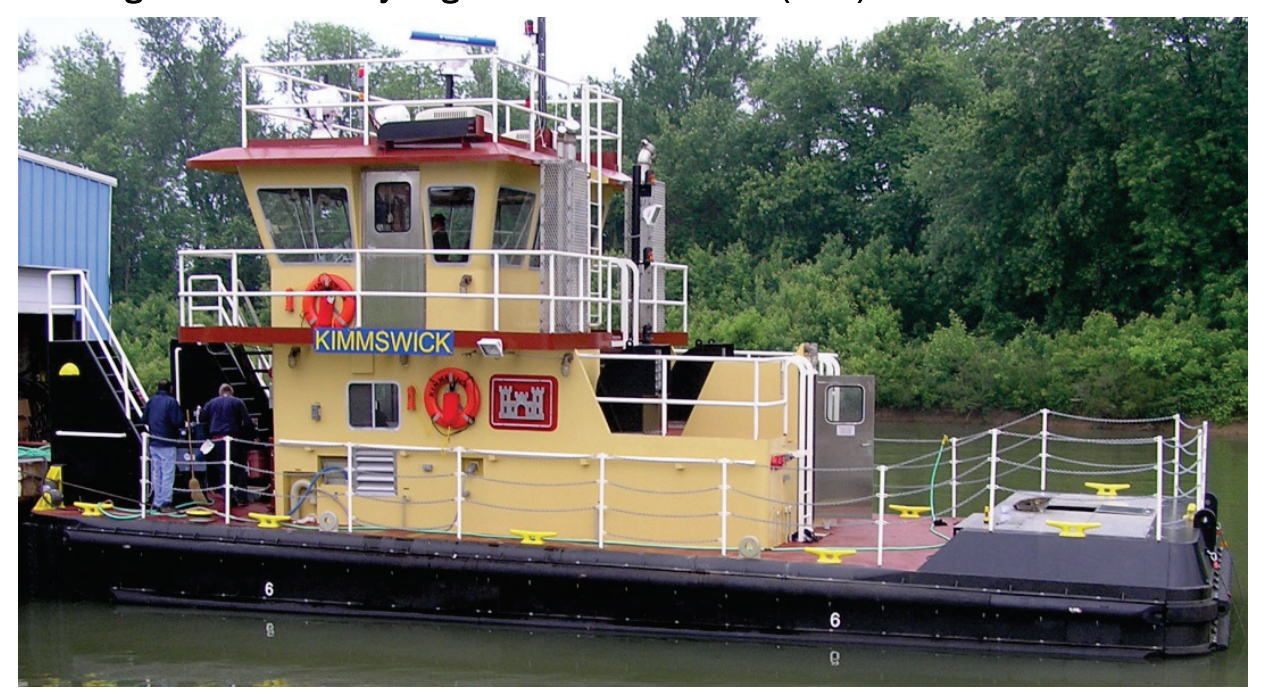

Figure A7. U.S. Army Engineer District St Louis (MVS) crane barge Fisher.

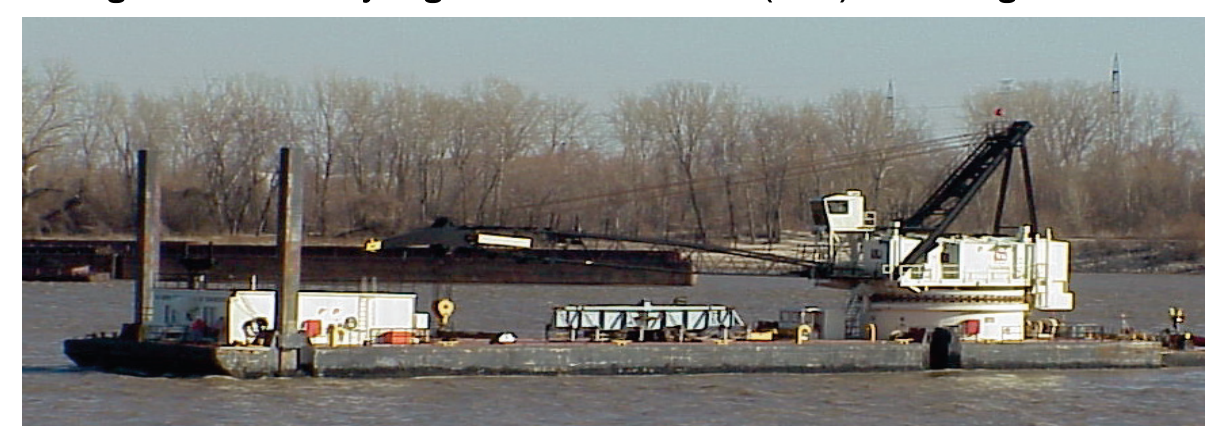

Figure A8. U.S. Army Engineer District St

Louis (MVS) crane barge Sewell.

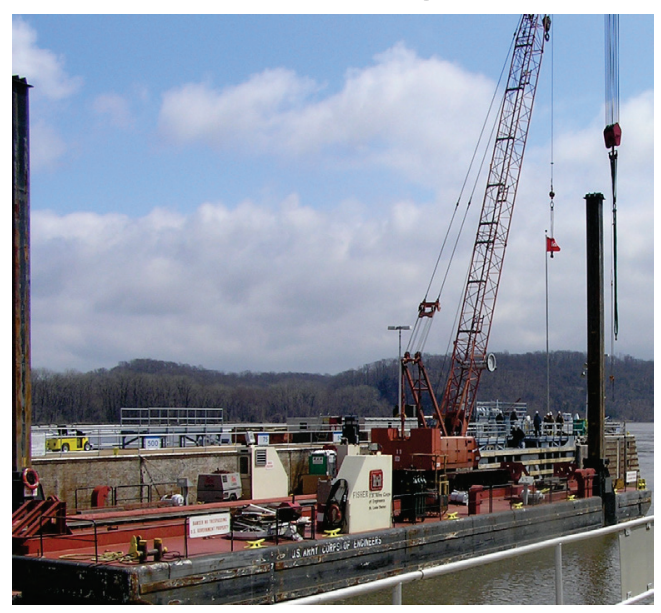


Figure A9. U.S. Army Engineer District St Louis (MVS) crewboat Barron.

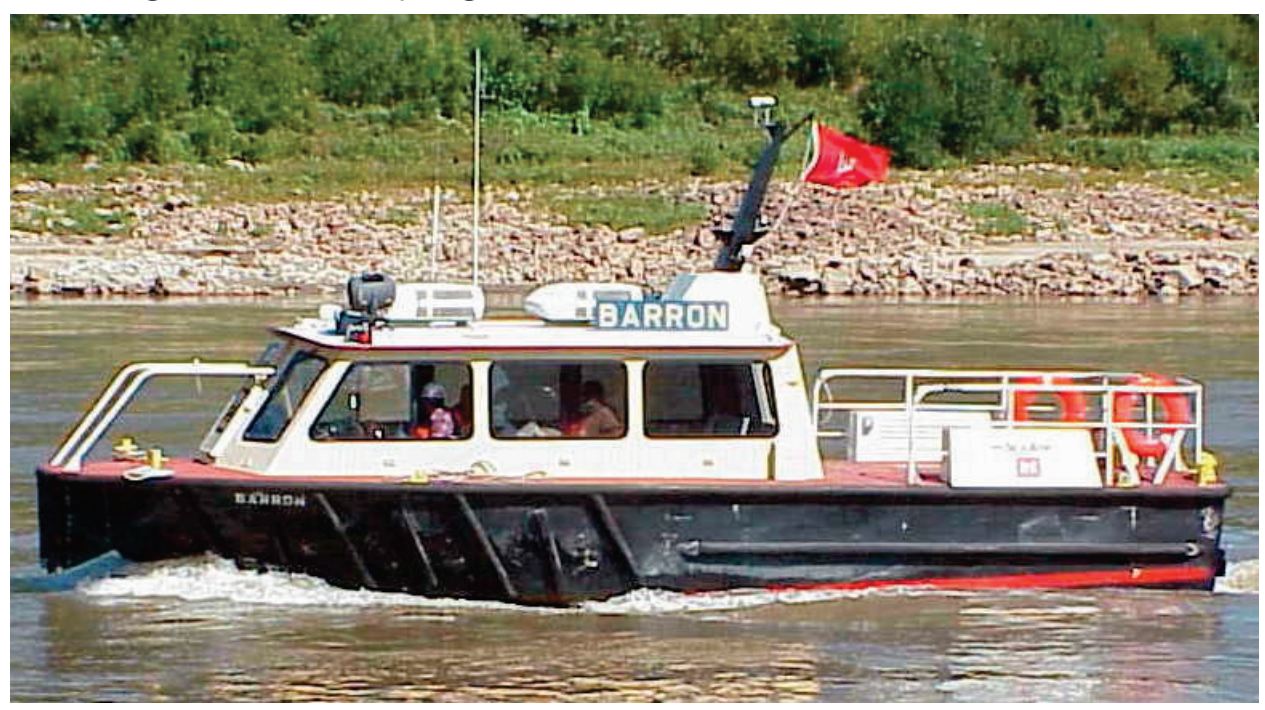

Figure A10. U.S. Army Engineer District St Louis (MVS) crane barge Derrick Number 6.

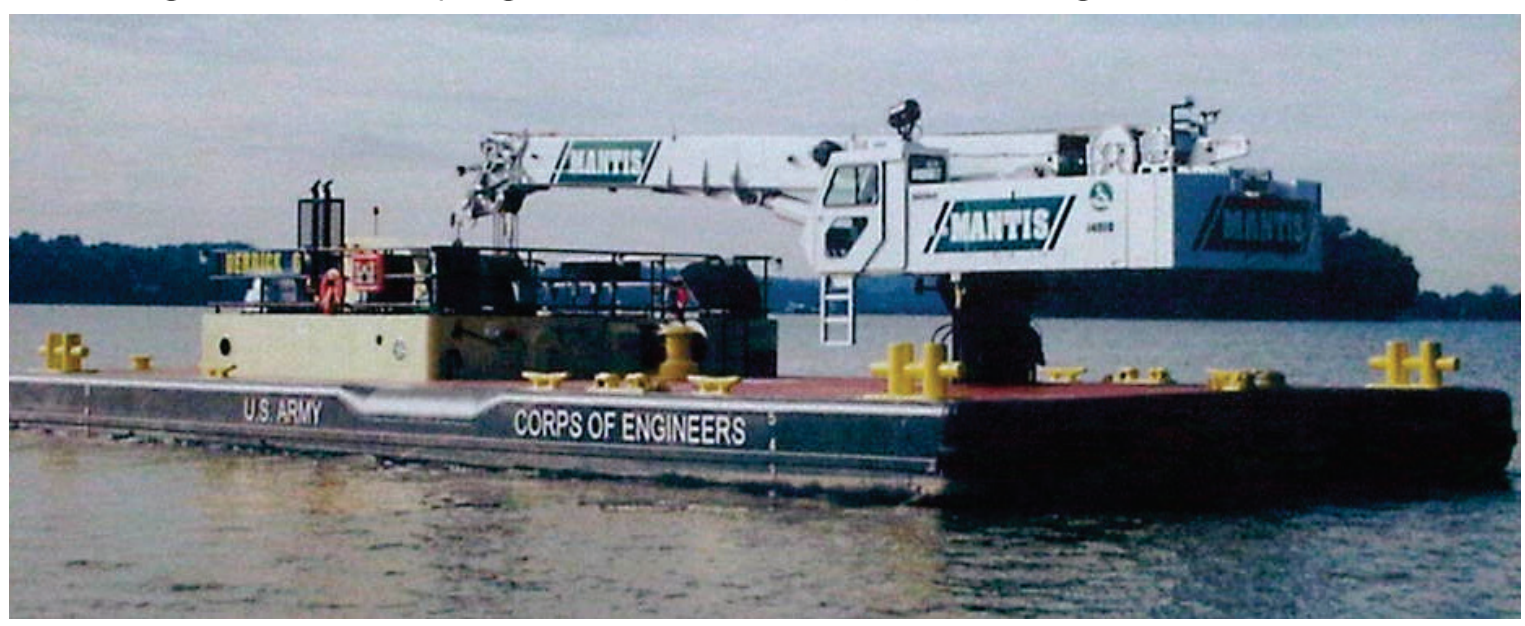




\section{Appendix B: ASTM D6751}

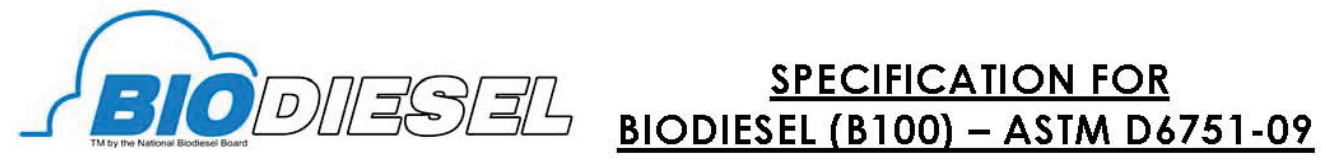

Nov. 2008

Biodiesel is defined as the mono alkyl esters of long chain fatty acids derived from vegetable oils or animal fats, for use in compression-ignition (diesel) engines. This specification is for pure (100\%) biodiesel prior to use or blending with diesel fuel. \#

\section{Property \\ Calcium \& Magnesium, combined}

Flash Point (closed cup)

\section{ASTM Method}

EN 14538

D 93

Limits

Units

Alcohol Control (One of the following must be met)

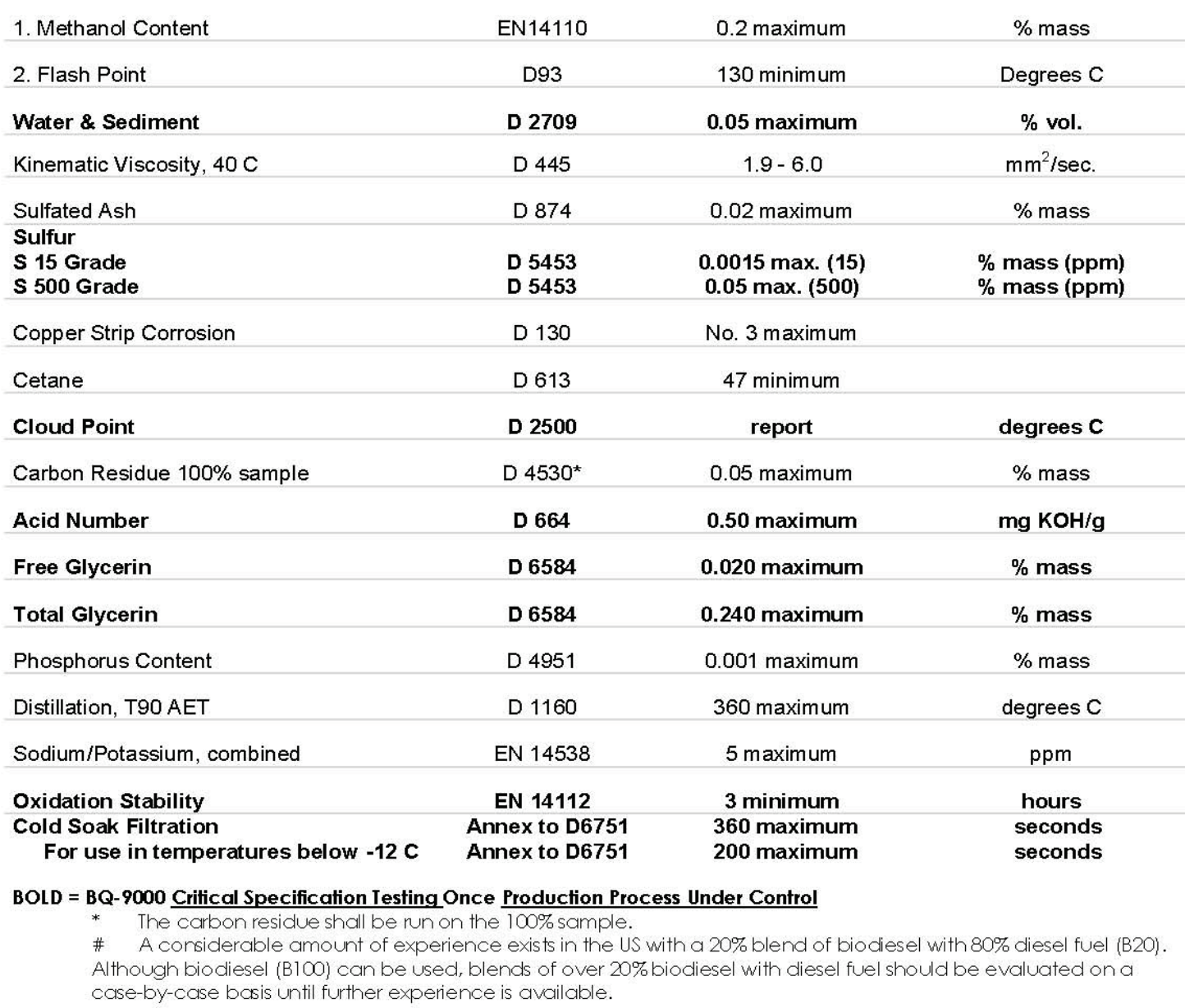

ppm (ug/g)

degrees C 


\section{Appendix C: B100 Test Results}

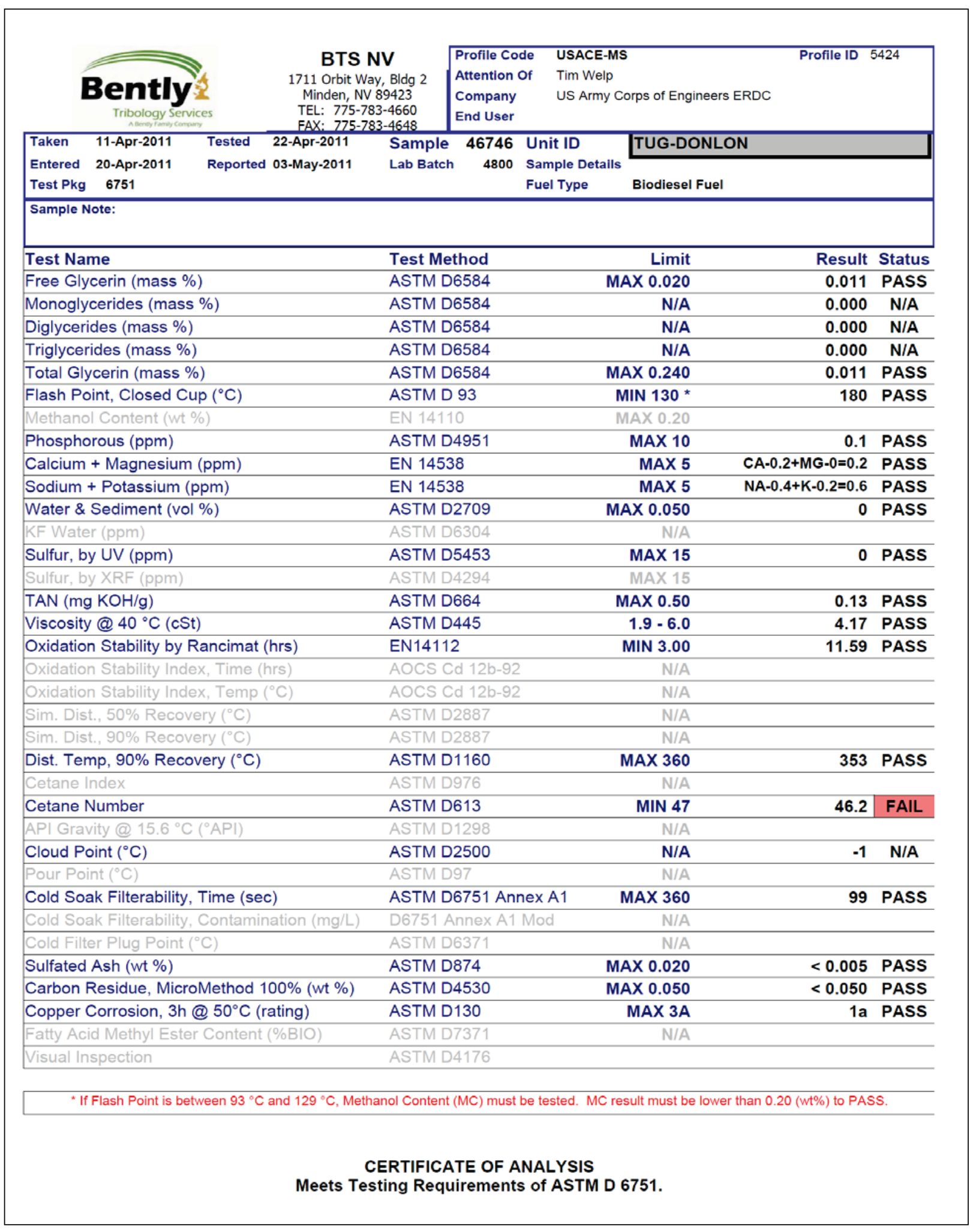




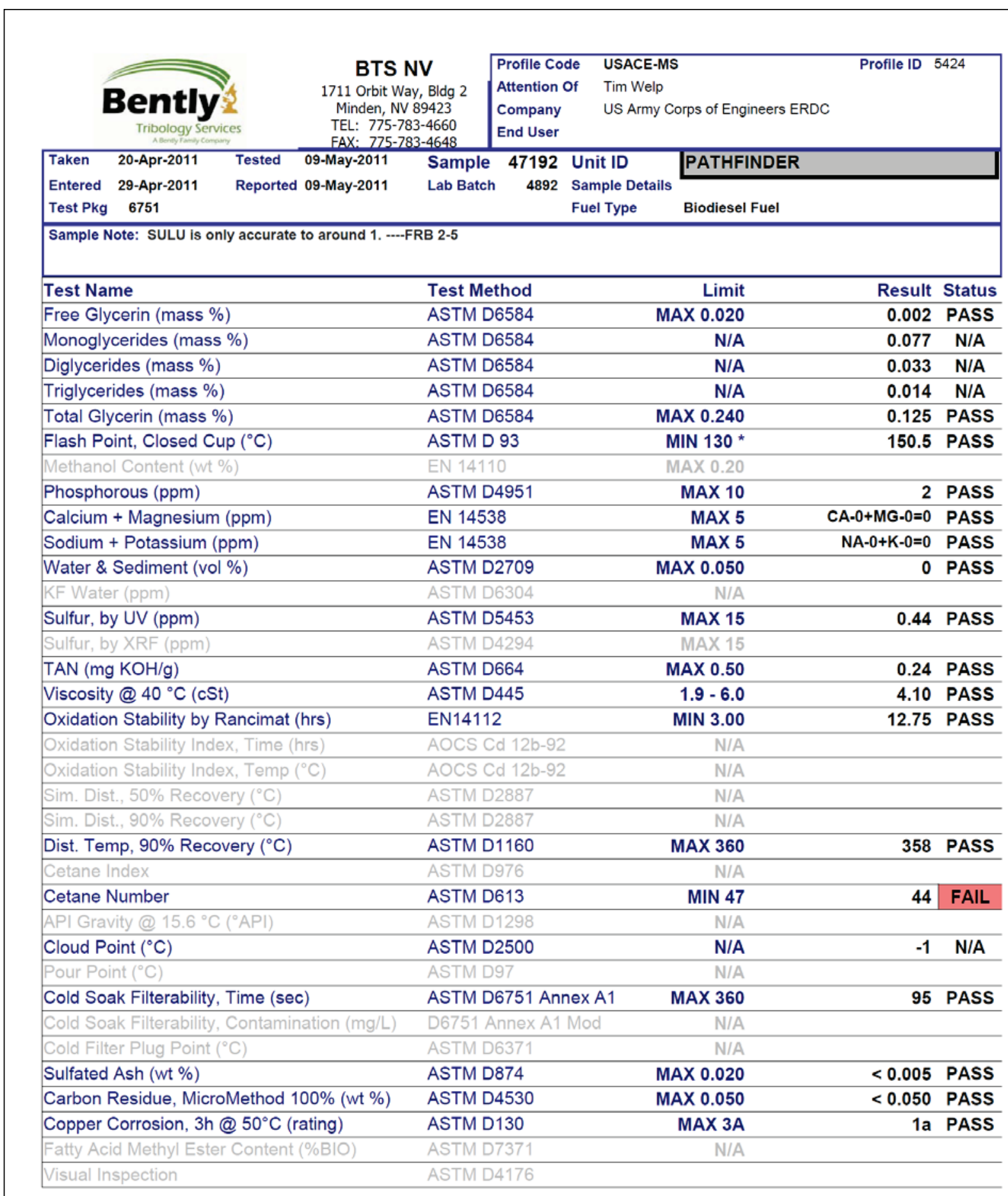




\begin{tabular}{|c|c|c|c|c|c|c|}
\hline \multirow{4}{*}{$\begin{array}{|lc|}\text { Taken } & \text { 09-Jun-2011 } \\
\text { Entered } & \text { 14-Jun-2011 } \\
\text { Test Pkg } & 6751 \\
\text { Sample Note: }\end{array}$} & $\begin{array}{l}\text { JV } \\
y, \text { Bldg } 2 \\
89423 \\
3-4660 \\
3-4648 \\
\end{array}$ & $\begin{array}{l}\text { Profile Coc } \\
\text { Attention C } \\
\text { Company } \\
\text { End User }\end{array}$ & $\begin{array}{ll}\text { ode } & \text { USACE-M } \\
\text { Of } & \text { Tim Welp } \\
& \text { US Army C } \\
\end{array}$ & Corps of Engin & Is ERDC & 5424 \\
\hline & \multirow{2}{*}{$\begin{array}{l}\text { Sample } \\
\text { Lab Batch }\end{array}$} & 49294 & \multirow{2}{*}{$\begin{array}{l}\text { Unit ID } \\
\text { Sample Detalls } \\
\text { Fuel Type }\end{array}$} & \multicolumn{2}{|c|}{ RACCOON-BLUE-SKY } & \\
\hline & & h 5249 & & Blodiesel FL & & \\
\hline & \multicolumn{6}{|c|}{ Sample Note: } \\
\hline Test Name & \multicolumn{2}{|c|}{ Test Method } & \multicolumn{4}{|c|}{ Result Status } \\
\hline Free Glycerin (mass \%) & \multicolumn{2}{|c|}{ ASTM D6584 } & \multicolumn{2}{|r|}{ MAX 0.020} & 0.001 & PASS \\
\hline Monoglycerides (mass \%) & \multicolumn{2}{|c|}{ ASTM D6584 } & \multicolumn{2}{|r|}{ N/A } & 0.070 & N/A \\
\hline Diglycerides (mass \%) & \multicolumn{2}{|c|}{ ASTM D6584 } & \multicolumn{2}{|r|}{ N/A } & 0.018 & N/A \\
\hline Triglycerides (mass \%) & \multicolumn{2}{|c|}{ ASTM D6584 } & \multicolumn{2}{|r|}{ N/A } & 0.006 & N/A \\
\hline Total Glycerin (mass \%) & \multicolumn{2}{|c|}{ ASTM D 6584} & \multicolumn{2}{|c|}{ MAX 0.240} & 0.095 & PASS \\
\hline Flash Point, Closed Cup $\left({ }^{\circ} \mathrm{C}\right)$ & \multicolumn{2}{|c|}{ ASTM D93 } & \multicolumn{2}{|r|}{ MIN 130} & 169 & PASS \\
\hline Phosphorous (ppm) & \multicolumn{2}{|c|}{ ASTM D4951 } & \multicolumn{2}{|r|}{ MAX 10} & 0 & PASS \\
\hline Calcium + Magnesium (ppm) & \multicolumn{2}{|c|}{ EN 14538} & \multicolumn{2}{|r|}{ MAX 5} & CA- $0.2+M G-0.1=0.3$ & PASS \\
\hline Sodium + Potassium (ppm) & EN 1453 & & & MAX 5 & NA- $0.1+K-0=0.1$ & PASS \\
\hline Water \& Sediment (vol \%) & ASTM D & 2709 & & $\operatorname{IAX} 0.050$ & 0 & PASS \\
\hline Sulfur, by UV (ppm) & ASTM D & 5453 & & MAX 15 & 2.84 & PASS \\
\hline TAN (mg KOH/g) & ASTM D & 6664 & & MAX 0.50 & 0.16 & PASS \\
\hline Viscosity @ 40 $\mathrm{C}$ (cSt) & ASTM D & 4445 & & $1.9-6.0$ & 5.00 & PASS \\
\hline Oxidation Stability of Diesel Fuels (hrs) & EN1575 & & & IIN 3.00 & 8.2 & PASS \\
\hline Dist. Temp., 90\% Recovery $\left({ }^{\circ} \mathrm{C}\right)$ & ASTM D & 1160 & & $\operatorname{MAX} 360$ & 359 & PASS \\
\hline Cetane Number & ASTM D & 2613 & & MIN 47 & 48 & PASS \\
\hline Cloud Point $\left({ }^{\circ} \mathrm{C}\right)$ & ASTM D & 2500 & & N/A & & N/A \\
\hline Cold Soak Filterability, Time (sec) & ASTM D & 7501 & & $\operatorname{MAX} 360$ & 110 & PASS \\
\hline Sulfated Ash (wt \%) & ASTM D & 8874 & & IAX 0.020 & $<0.005$ & PASS \\
\hline Carbon Residue, MicroMethod 100\% (wt \%) & ASTM D & 4530 & & $\operatorname{IAX} 0.050$ & $<0.05$ & PASS \\
\hline Copper Corrosion, 3h @ 50C (rating) & ASTM D & 2130 & & MAX 3A & $1 \mathrm{a}$ & PASS \\
\hline
\end{tabular}

CERTIFICATE OF ANALYSIS

Analysis Meets Testing Requirements of ASTM D 6751. 


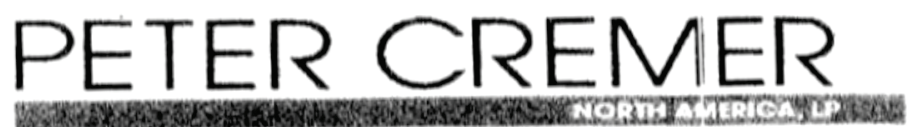

NEXSOL BD-99.9 BIODIESEL ASTM D 6751 (EPA 4627)

Lot \#: PN027311043

\begin{tabular}{|c|c|c|c|}
\hline Property & ASTM Method & Limits & Results \\
\hline Flash Point & D93 & $93^{\circ} \mathrm{C} \min$ & $>150^{\circ} \mathrm{C}$ \\
\hline Water \& Sediment & D2709 & $0.050 \%$ vol. $\max$ & $\div 0.025$ \\
\hline Kinematic Viscosity, $40^{\circ} \mathrm{C}$ & D445 & $1.9-6.0 \mathrm{~mm}^{2} / \mathrm{sec}$ & 4.0 \\
\hline Sulfated Ash & D 874 & $0.020 \%$ mass max & $<0.005$ \\
\hline Sulfur & D5453 & $15 p p m \max$ & $<1$ \\
\hline Copper Strip Corrosion & D130 & No. 3 max & la \\
\hline Cetane & D613 & $47 \mathrm{~min}$. & 55 \\
\hline Cloud Point & D2500 & Report to customer & $0^{\circ} \mathrm{C}$ \\
\hline Carbon Residue, $100 \%$ sample & D4530 & $0.050 \%$ mass $\max$ & $<0.001$ \\
\hline Acid Number & D664 & $0.50 \mathrm{mg}$ KOH/gm max & 0.16 \\
\hline Free Glycerin & D6584 & $0.020 \%$ mass $\max$ & 0.012 \\
\hline Monoglycerides & D6584 & $0.8 \%(\mathrm{~m} / \mathrm{m}) \max$ & 0.100 \\
\hline Diglycerides & D6584 & $0.2 \%(\mathrm{~m} / \mathrm{m}) \max$ & 0.050 \\
\hline Triglycerides & D6584 & $0.2 \%(\mathrm{~m} / \mathrm{m}) \max$ & 0.050 \\
\hline Total Glycerin & D6584 & $0.240 \%$ mass max & 0.050 \\
\hline Phosphorus Content & D4951 & $0.001 \%$ mass max & 0.000 \\
\hline $\begin{array}{l}\text { Distillation temp., atmospheric } \\
\text { equiv. temp., } 90 \% \text { recovered }\end{array}$ & D1160 & $360^{\circ} \mathrm{C} \max$ & $352^{\circ} \mathrm{C}$ \\
\hline Sodium \& Potassium Metals & EN 14538 & 5ppm max combined & $<1.0$ \\
\hline Calcium \& Magnesium Metals & EN 14538 & 5ppm max combined & $<1.0$ \\
\hline Oxidation Stability & EN 15751 & 3 hours min & 6 \\
\hline Visual Inspection & D $4176(42)$ & $2 \max$ & 1 \\
\hline Cold Soak Filtration & D6751 Appendix & 360 seconds max & 91 \\
\hline Water Content by Karl Fisher & D6304 & $500 \mathrm{ppm}$ & 42 \\
\hline
\end{tabular}

' B100 (or B99 9) intended for blending into diesel fuel that is expected to give sutisfactory vehicic erformancent fuel temperatures at or below $.12 \cdot \mathrm{C}$ shall comply with a cold soak filterability limit of 200 seconds $\mathrm{n}$... Ium

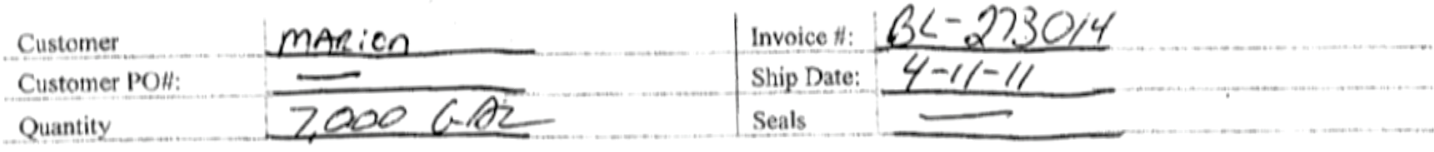

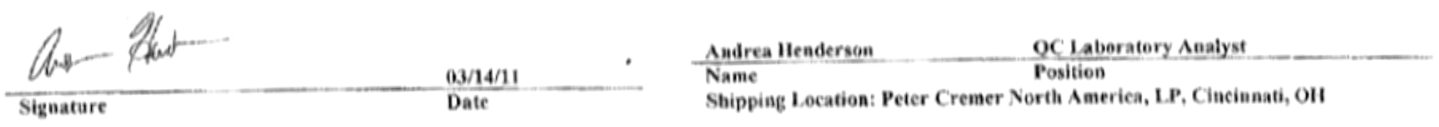

This analysis is not to be construed as a warranty. Customer is responsible to verify the lot and code numbers of produet received with the numbers contained on this report and perform any other analyses necessary to determine suitability of the product described above for the use intended by the customer

"Peter Cremer North Americu, LP is a registered BQ- $9000^{\star}$ Producer and Marketer"

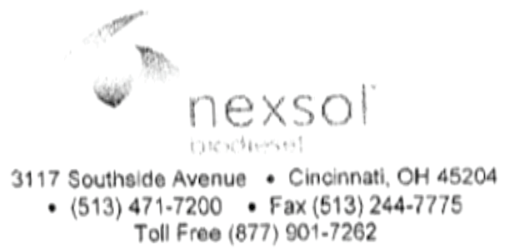




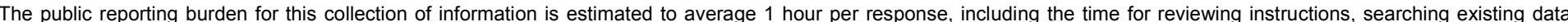

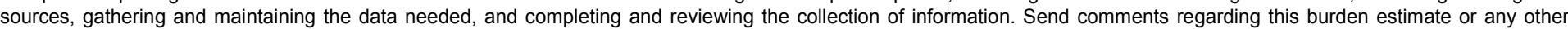

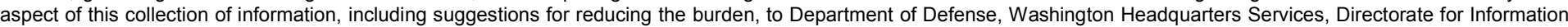

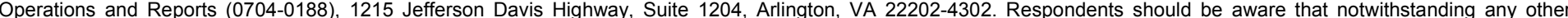
provision of law, no person shall be subject to any penalty for failing to comply with a collection of information if it does not display a currently valid OMB control number. PLEASE DO NOT RETURN YOUR FORM TO THE ABOVE ADDRESS.

\begin{tabular}{l|l|l}
\hline 1. REPORT DATE & 2. REPORT TYPE & 3. DATES COVERED (From - To) \\
July 2016 & Technical Report & Oct $2010-$ Jan 2015
\end{tabular}

\title{
4. TITLE AND SUBTITLE
}

5a. CONTRACT NUMBER

Evaluation of Biodiesel Fuels to Reduce Fossil Fuel Use in Corps of Engineers'

Floating Plant Operations

5b. GRANT NUMBER

5c. PROGRAM ELEMENT NUMBER

\section{AUTHOR(S)}

Michael Tubman, Timothy Welp, Ryan Immel, and Robert Leitch

5d. PROJECT NUMBER

5e. TASK NUMBER

5f. WORK UNIT NUMBER 456009

\section{PERFORMING ORGANIZATION NAME(S) AND ADDRESS(ES)}

US Army Corps of Engineers

8. PERFORMING ORGANIZATION

Engineer Research and Development Center REPORT NUMBER

3909 Halls Ferry Road

ERDC/CHL TR-16-11

Vicksburg MS, 39180

9. SPONSORING/MONITORING AGENCY NAME(S) AND ADDRESS(ES)

U.S. Army Corps of Engineers

Washington, DC 20314-1000

\author{
10. SPONSOR/MONITOR'S ACRONYM(S) \\ HQUSACE
}

\section{SPONSOR/MONITOR'S REPORT NUMBER(S)}

\section{DISTRIBUTION/AVAILABILITY STATEMENT}

Approved for public release; distribution is unlimited.

\section{SUPPLEMENTARY NOTES}

\section{ABSTRACT}

A study to evaluate the feasibility of using biodiesel fuel in U.S. Army Corps of Engineers (USACE) floating plant operations to reduce environmentally sensitive emissions, increase use of renewable energy, and reduce the use of fossil fuels was conducted with funding from the U.S. Army Corps of Engineers (USACE) Dredging Operations and Environmental Research (DOER) program and the USACE Sustainability and Energy Efficiency Program. This study was conducted by the USACE Engineer Research and Development Center (ERDC) and the USACE Marine Design Center (MDC), in conjunction with support of USACE Headquarters (HQUSACE) and participating USACE Districts. The study began in 2010 with a focus on the methodology to convert four working USACE vessels to biodiesel. Favorable results in regards to mechanical and operational issues cleared the way for evaluating biodiesel on additional vessels. Fourteen vessels were converted to biodiesel use in the expanded study, and additional tests of emissions and fuel usage were conducted on two vessels. This report describes the study that successfully demonstrated that use of certified biodiesel fuel (including biodiesel manufactured from soybeans and from algal oils) by suitable USACE floating plants is feasible to reduce select environmentally sensitive emissions, increase USACE use of renewable energy, and reduce the use of fossil fuels.

\section{SUBJECT TERMS}

Biodiesel fuels

Energy consumption

\section{SECURITY CLASSIFICATION OF:}

\begin{tabular}{|l|l|l|}
\hline a. REPORT & b. ABSTRACT & c. THIS PAGE \\
Unclassified & Unclassified & Unclassified \\
\hline
\end{tabular}

Fuel consumption

Greenhouse gas mitigation

Marine engines - Exhaust gas

\section{LIMITATION OF 1 18. NUMBER OF ABSTRACT \\ PAGES} UU
60
Renewable energy sources

Soybeans Sustainability

19a. NAME OF RESPONSIBLE PERSON Timothy Welp

19b. TELEPHONE NUMBER (Include area code) 601-634-2083 